Engineer Research and

Development Center

Engineering With Nature (EWN)

\title{
A Multifactor Ecosystem Assessment of Wetlands Created Using a Novel Dredged Material Placement Technique in the Atchafalaya River, Louisiana
}

An Engineering With Nature Demonstration Project

Jacob F. Berkowitz, Sung-Chan Kim, Nathan R. Beane, Darrell

E. Evans, Elizabeth Summers, Burton Suedel, Maik Flanagin, and Jeff Corbino

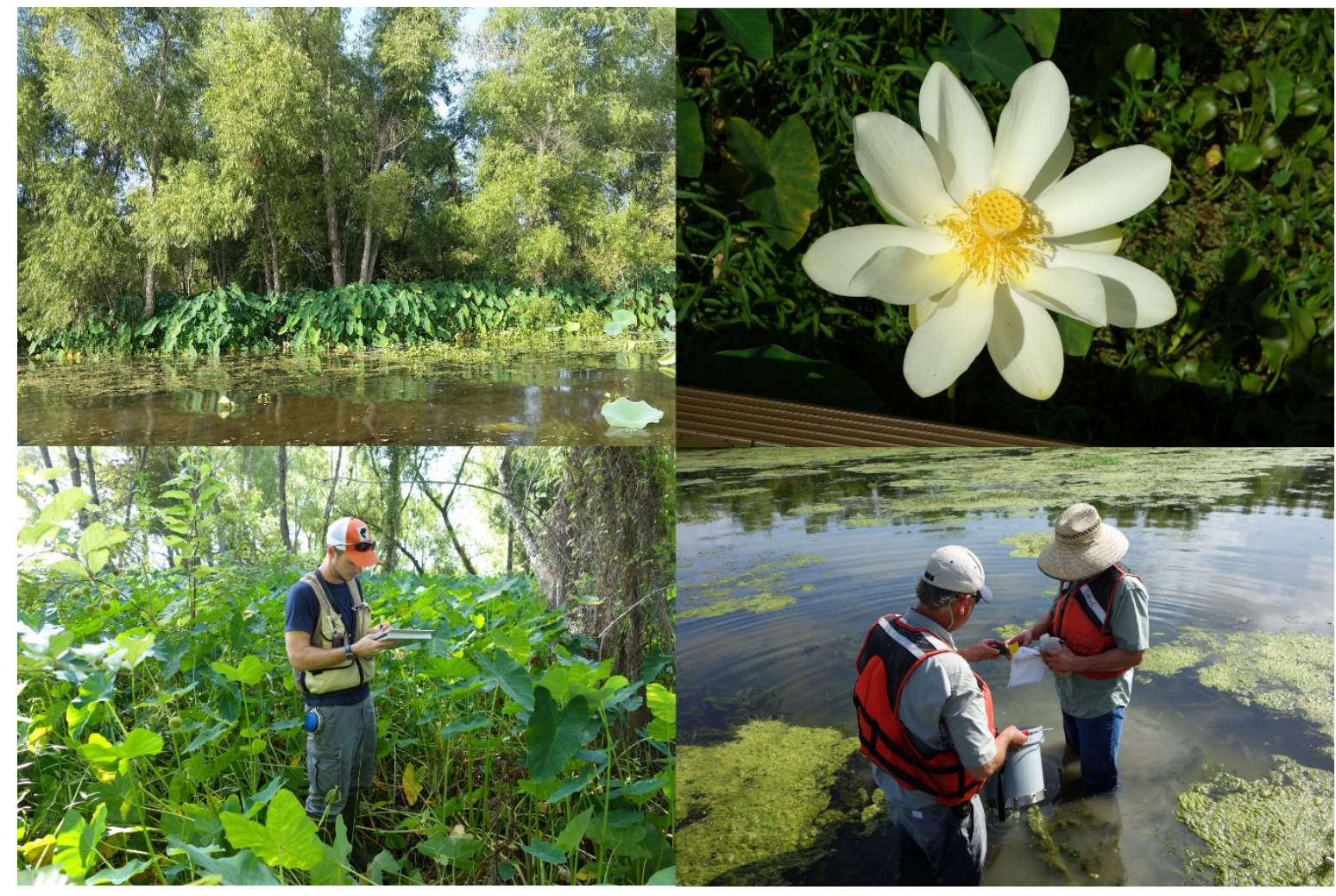


The U.S. Army Engineer Research and Development Center (ERDC) solves the nation's toughest engineering and environmental challenges. ERDC develops innovative solutions in civil and military engineering, geospatial sciences, water resources, and environmental sciences for the Army, the Department of Defense, civilian agencies, and our nation's public good. Find out more at www.erdc.usace.army.mil.

To search for other technical reports published by ERDC, visit the ERDC online library at http://acwc.sdp.sirsi.net/client/default. 


\section{A Multifactor Ecosystem Assessment of Wetlands Created Using a Novel Dredged Material Placement Technique in the Atchafalaya River, Louisiana}

\section{An Engineering With Nature Demonstration Project}

Jacob F. Berkowitz, Nathan R. Beane, Darrell E. Evans, Elizabeth Summers, and Burton Suedel

U.S. Army Engineer Research and Development Center (ERDC)

Environmental Laboratory (EL)

3909 Halls Ferry Road

Vicksburg, MS 39180-6199

Sung-Chan Kim

U.S. Army Engineer Research and Development Center

Coastal and Hydraulics Laboratory (CHL)

3909 Halls Ferry Road

Vicksburg, MS 39180-6199

Maik Flanagin and Jeff Corbino

U.S. Army Corps of Engineers (USACE), New Orleans District

P.O. Box 60267

New Orleans, LA 70160

Final Report

Approved for public release; distribution is unlimited.

Prepared for Engineering With Nature

U.S. Army Engineer Research and Development Center (ERDC)

Environmental Laboratory (EL)

3909 Halls Ferry Road

Vicksburg, MS 39180-6199 


\section{Abstract}

A multifactor ecosystem assessment of dredged material supported wetlands was conducted within the Atchafalaya River, Louisiana. The assessment included evaluations of (1) geomorphic evolution, (2) ecosystem classification and distribution, (3) floral communities, (4) avian communities, (5) aquatic invertebrates, (6) soils and biogeochemical activity, and (7) hydrodynamic and sediment transport processes. Results indicate that the innovative use of dredged materials in a riverine environment supports wetland formation and expansion while providing habitat, hydrologic, and biogeochemical functions. The strategic placement of dredged materials in locations that mimic natural process promoted additional ecological benefits, especially regarding wading bird and infaunal habitat, thus adhering to Engineering With Nature (EWN) processes. The multifactor approach improved the wetland assessment, allowing for a comprehensive ecosystem-level analysis of a diverse array of ecosystem components and functions. 


\section{Contents}

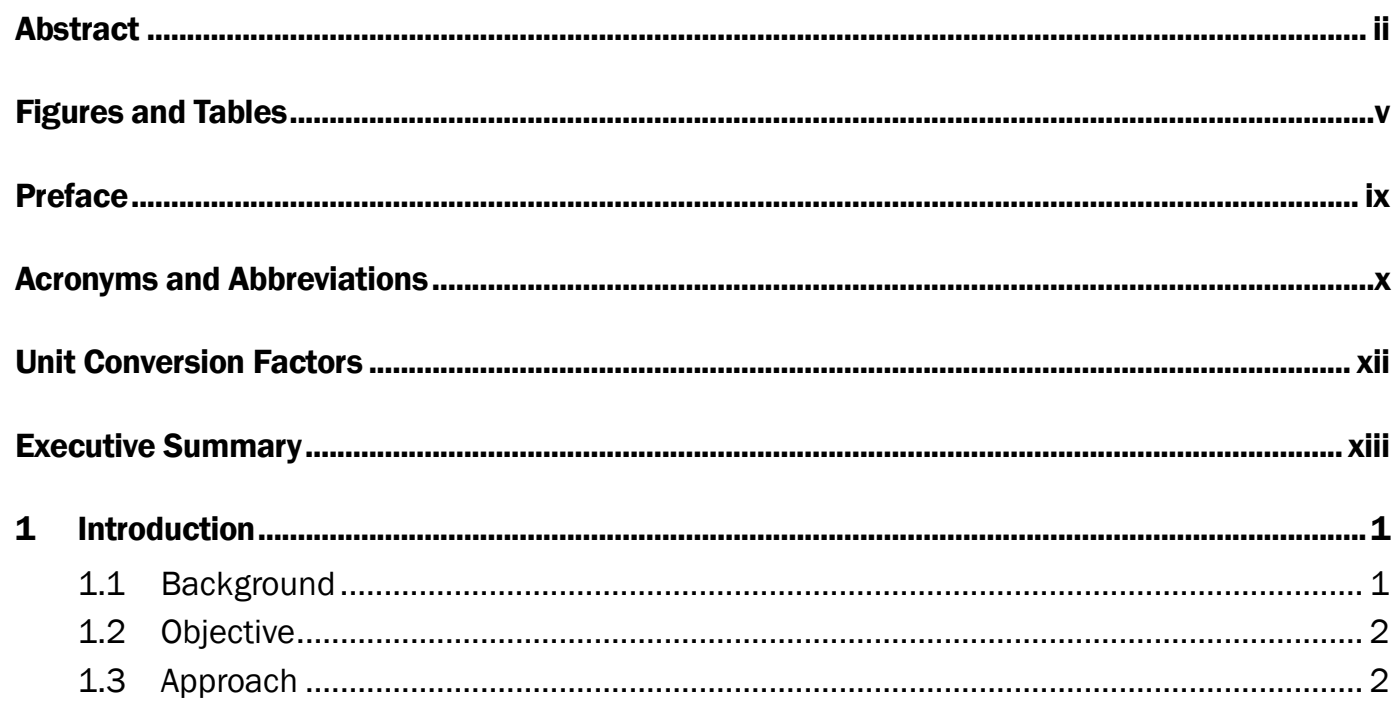

2 Study Area

3 Horseshoe Bend Island Image Analysis and Geomorphic Evolution .................................... 8

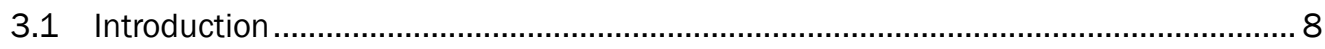

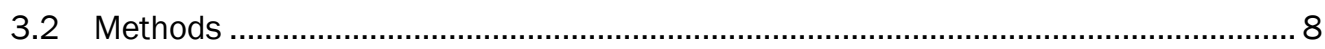

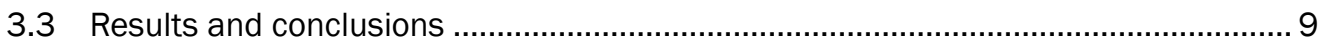

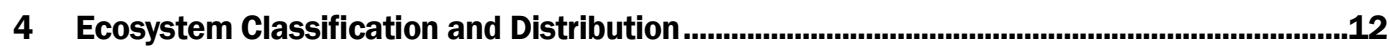

4.1 Wetland classification ...................................................................................... 12

4.2 Ecosystem distribution ..................................................................................... 16

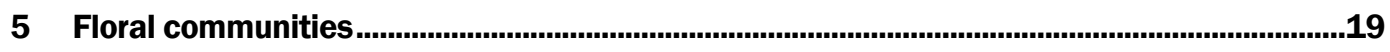

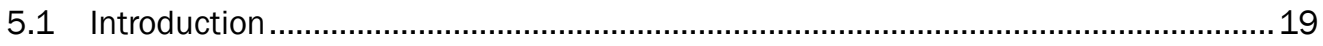

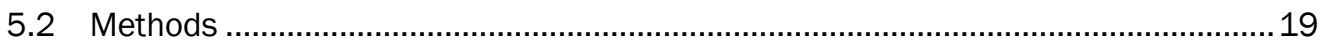

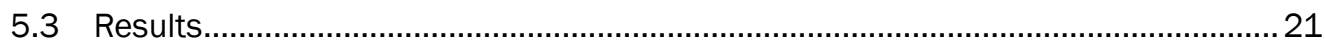

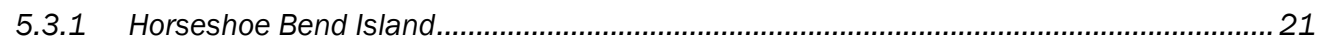

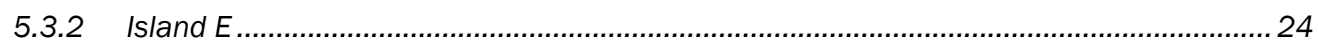

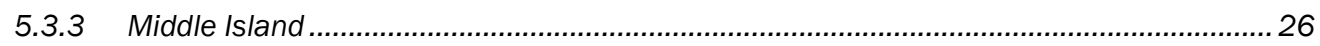

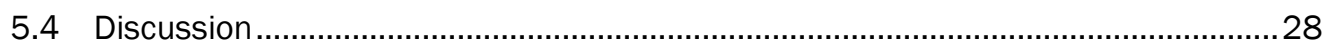

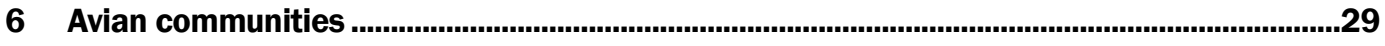

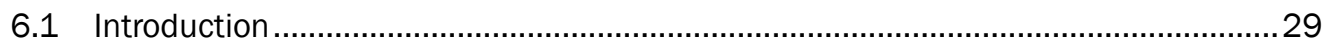

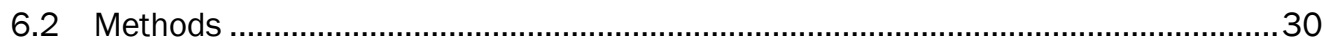

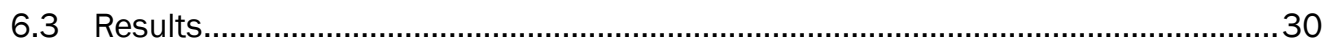

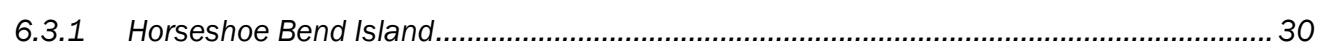

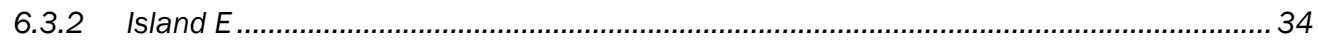

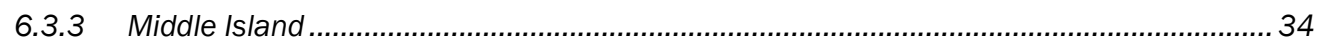

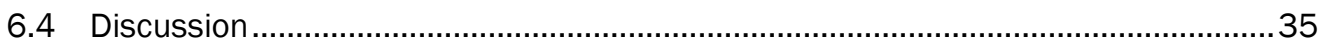




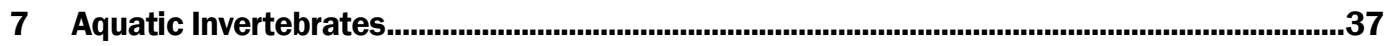

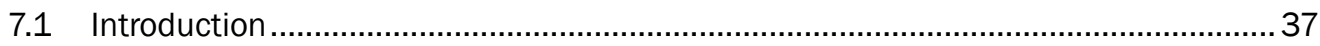

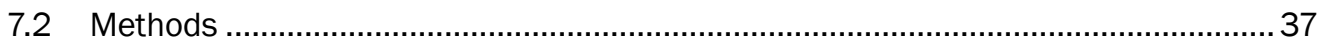

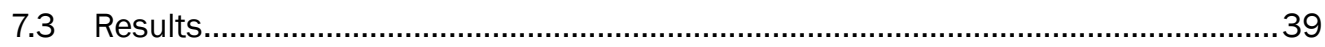

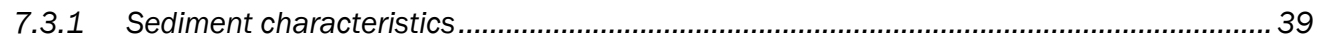

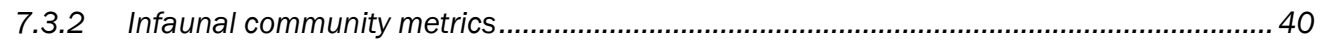

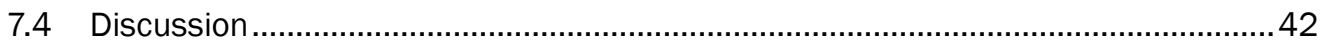

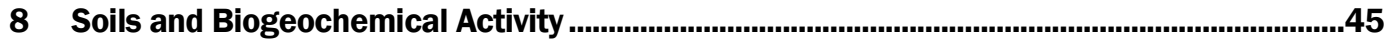

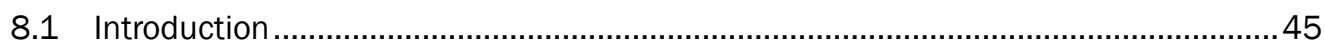

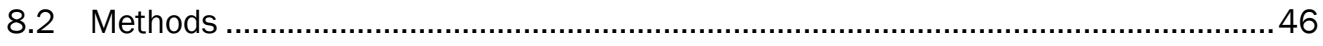

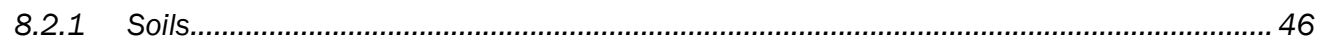

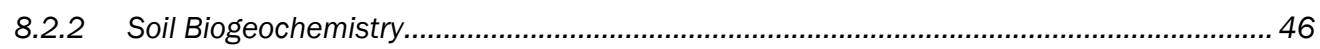

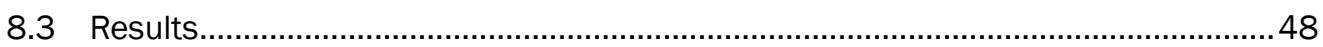

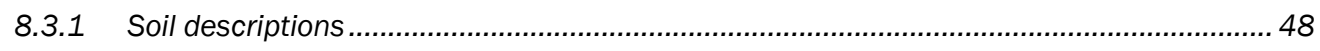

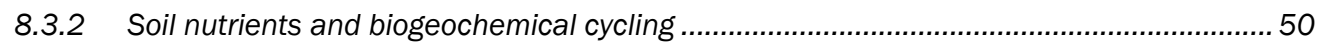

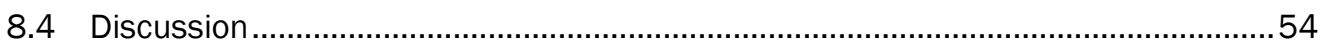

9 Hydrodynamics and Sediment Transport Modeling............................................................57

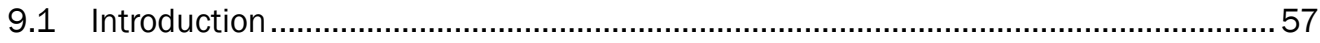

9.2 Curvilinear Hydrodynamics in Three Dimensions (CH3D) Model..............................59

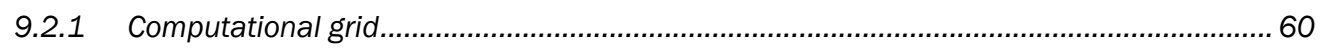

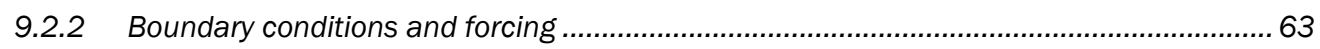

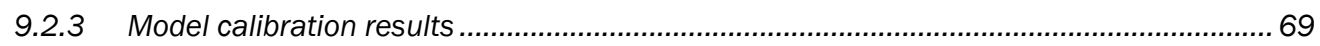

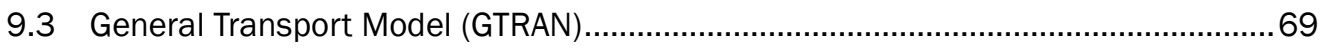

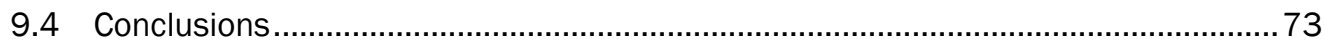

10 Discussion and Conclusions ................................................................................................... 74

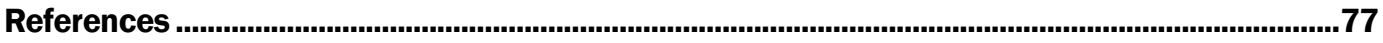

\section{Appendix A: List of Plant Species Observed at Horseshoe Bend Island, Middle Island,}

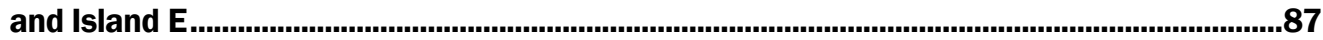

\section{Report Documentation Page}




\section{Figures and Tables}

\section{Figures}

1 Study location within the lower Atchafalaya River, St. Mary Parish, LA (indicated

by the rectangle).

2 Dredged material placement history within the study reach between 1990 and 1999 (University of New Orleans 2002). Note the presence of Island E (rectangle) near the top of the image; Horseshoe Bend Island (circle) was not present in 1999.

3 Imagery displaying island location prior to dredged material (DM) placement and subsequent formation (1992 and 1998 images), establishment, and growth since strategic dredged material placement began in 2002. (Imagery provided by USACE MVN.)

4 Horseshoe Bend Island, a 35 ha island supported by strategic dredged material placement. Note the small dredged material mound (circled) placed immediately upriver (north) of the island. Image dated 28 October $2012 .$.

5 Land-water geomorphology for Horseshoe Bend Island for years 2007 through 2012, with 2012 representing the base condition. The areas in orange indicate the algorithm-estimated aerial land cover detected during each of the years examined.

6 BUMP images of Horseshoe Bend Island (a) 2008, (b) 2009, (c) 2010, (d) 2011, (e) 2012, (f) 2013, and (g) 2014

7 Ecosystem classification results at (a) Horseshoe Bend Island, (b) Island E, and (c) Middle Island. Note that palustrine forested areas are shown in green, aquatic bed features appear in blue, scrub-shrub wetlands are in yellow, and emergent wetlands are denoted in purple.

8 Average elevation of wetland classes identified at Horseshoe Bend Island and Island E. Error bars represent standard error of the mean. Wetland classes with a different letter had statistically different elevations.

9 Habitat map of the Horseshoe Bend portion of the Atchafalaya River in 2001 (University of New Orleans 2002). The circle indicates the location of Island E; the square outlines Horseshoe Bend Island and a small dredged material feeder mound to the north. Note that the authors identified forested, shrub/scrub, and marsh (i.e., emergent) wetland classes

10 Vegetation sampling scheme used for characterize forested, scrub-shrub, and

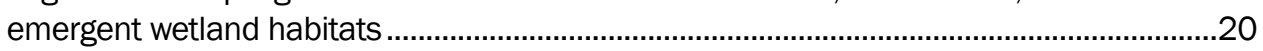

11 A forested wetland sample location on Horseshoe Bend Island ........................................21

12 An aquatic bed wetland sample location on Horseshoe Bend Island ................................23

13 A sample location on Island $E$. A forested wetland area can be seen in the foreground with an emergent wetland area in the background of the image .....................25

14 Emergent wetland surrounded by a forested wetland area at a Middle Island sampling location ................................................................................................................2

15 Wading-bird nesting colony on Horseshoe Bend Island .....................................................32

16 Juvenile tricolored heron observed during a transect survey on Horseshoe Bend Island. 
17 Juvenile snowy egret observed during a transect survey on Horseshoe Bend

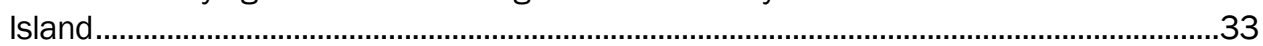

18 Juvenile glossy ibis observed during a transect survey on Horseshoe Bend Island ............33

19 Forested wetland area within the wading-bird rookery on Horseshoe Bend Island. Note the presence of standing water below the nesting colony ..........................................34

20 Left, the infaunal community sampling locations at Horseshoe Bend Island. Note that triplicate core samples were collected at the wetland edge and at five emergent aquatic bed (EAB) locations. Right, infaunal sampling used a $7.5 \mathrm{~cm}$ coring device

21 Sediment organic matter content at Horseshoe Bend wetland edge (HB) and emergent aquatic bed (HB EAB), Island $E$ river shoreline (IE) and emergent aquatic bed (IE EAB), and Middle Island sample locations. Note that the emergent aquatic bed sediments ${ }^{*}$ ) contained significantly more organic matter than river shoreline locations

22 Soil carbon and nitrogen concentrations showed increases with stand age on Horseshoe Bend Island

23 Comparison of (a) soil carbon (C), (b) soil nitrogen (N), (c) soil organic matter, and (d) bulk density at Horseshoe Bend Island and Island E. Columns with different letters were statistically different; error bars represent standard error

24 Horseshoe Bend Island and the lower Atchafalaya River basin in coastal Louisiana. North is at the top of the figure

25 Sounding data from NOAA's Electronic Navigation Chart (units in meters) 60

RMA-2 grid with bathymetry data (units in feet)

30 Gage locations for Lower Atchafalaya River. Triangles (blue) represent USGS gage locations, circles (purple) are for NOAA tide gage locations, and the asterisk (green) denotes a meteorological station

31 Gage heights from USGS gages over the 7-year period between water years 2007 and 2013. Gages are 7381600 (upper left panel), 73816202 (lower left panel), 73814675 (upper right panel), and 73816503 (lower right panel)

32 Intra-annual variability of the hydrology record across select USGS and NOAA gages for water year 2012. Shown are gage height (ft) for USGS gage 7381600 (upper left panel), and for NOAA gages 8764044 (blue) and 8764227 (green), water levels ( $\mathrm{m}$; lower left panel), surface pressure ( $\mathrm{mb}$, upper right panel), and wind speed $(\mathrm{m} / \mathrm{s}$; lower right panel).

33 Flow boundary conditions in 2012 using data from three USGS gage stations. .66

34 Seven locations (green triangles) used for obtaining water level data along the open boundaries. The green circle near the entrance of Atchafalaya River marks the location of NOAA gage 8764227 .

35 Water levels at NOAA gage 8764227 for 2012 that identified six meteorological events in the study area

36 Wind speed (top panel) and direction (bottom panel) at NOAA gage 8764227

37 Predicted (red lines) and observed (blue dots) hourly water levels for the first 4 months of 2012 at NOAA gage 8764044 at Berwick, LA, and NOAA gage 
38 Median grain size of bottom sediments in the study area .............................................70

39 Assigned median grain size based on existing data shown in Fig. 40 ................................70

40 Assigned median grain size to CH3D model grid ............................................................... 71

41 Mean bottom current during the relatively wet season from January through

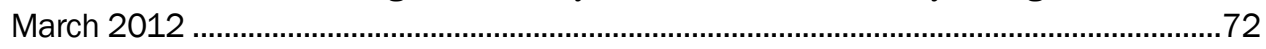

42 Mean bottom currents during the relatively dry season from July through

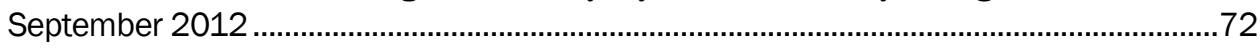

43 Mean suspended sediment transport rate from January through March 2012 ………......72

44 Mean bedload transport rate from January through March 2012 …..................................73

45 Conceptual model of the multifactor-assessment approach applied at Horseshoe Bend Island

\section{Tables}

1 Areal extent of wetland classification types within each island studied. Note that all wetland area created at Horseshoe Bend Island and Island E resulted from dredged material placement; Middle Island formed naturally.

2 Habitat classification changes (hectares) of Horseshoe Bend Island between 1985 and 2001. (Adapted from University of New Orleans [2002].)

3 Estimated area (hectares) of estuarine and palustrine wetlands along the Gulf of Mexico. (Adapted from Stedman and Dahl [2008] and Engle [2011]).

4 Vegetation summary for wooded areas of Horseshoe Bend Island. Data include the number of trees within each sample plot, dominant tree species, tree density, shrub-sapling density, ground vegetation within each sample plot, and average percent ground cover.

5 Percent cover estimates for floating and submerged vegetation on Horseshoe Bend Island

6 Vegetation summary for forested and scrub-shrub wetlands on Island E. Data include the number of trees within each sample plot, dominant tree species, tree density, shrub-sapling density, ground vegetation within each sample plot, and average percent ground cover

7 Percent cover estimates for floating and submerged vegetation on Island $\mathrm{E}$

8 Vegetation summary for wooded areas of Middle Island. Data include the number of trees within each sample plot, dominant tree species, shrub-sapling density, ground vegetation within each sample plot, and average percent ground cover.

9 Comparison of bird community metrics across the three islands studied ..........................31

10 Bird Species observed at Horseshoe Bend Island, Island E, and Middle Island ..................31

11 Average sediment particle size distribution for Horseshoe Bend river wetland edge (HB) and emergent aquatic bed (HB EAB), Island E wetland edge (IE) and emergent aquatic bed (IE EAB), and Middle Island (MI) sample locations

12 Average infauna community metrics at Horseshoe Bend Island (HB), Island $E$ (IE), and Middle Island (MI). Sampling locations included wetland edge (Edge) and emergent aquatic bed (EAB)

13 Statistical comparisons of infauna community metrics between sampling locations. Wetland site interaction included all three islands: Horseshoe Bend Island (HB), Island E (IE), and Middle Island (MI). Pair-wise comparisons were 
conducted between each wetland combination (e.g., HB vs. IE) and between the two sampling locations (Edge and EAB). Statistically significant results appear in bold $(\alpha=0.05)$.

14 Soil descriptions indicating layer depth $(\mathrm{cm})$, matrix color, redoximorphic features, and soil texture at each sample plot

15 Soil physical, nutrient, and biogeochemical properties and estimated nitrate removal calculation ( \pm standard error) at Horseshoe Bend Island (HB) and Island $\mathrm{E}(\mathrm{IE})$ habitats .51

16 Tidal harmonics at the Lawma gage station, LA (NOAA 2013) ........................................64

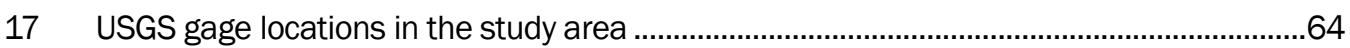




\section{Preface}

This study was conducted for the Engineer Research and Development Center's Engineering With Nature initiative and was funded by the U.S. Army Corps of Engineers Dredging Operations and Environmental Research (DOER) Program. The Program Manager was Dr. Todd Bridges, CEERD-EMD.

The work was performed by the Wetlands and Coastal Ecology Branch (CEERD-EEW) of the Ecosystem Evaluation and Engineering Division (CEERD-EE), U.S. Army Engineer Research and Development Center, Environmental Laboratory (ERDC-EL). At the time of publication, Ms. Patricia Tolley was Chief, CEERD-EEW; Mr. Mark Farr was Chief, CEERD-EE; and Mr. J eff Lillycrop, ERDC Coastal and Hydraulics Laboratory (CHL), was the ERDC Technical Director for Civil Works and Navigation Research, Development, and Technology. The Deputy Director of ERDC-EL was Dr. J ack Davis, and the Director was Dr. Beth Fleming.

Thanks to Mr. Brandon Gaspard and Mr. J ohn Newton for help with field work and plant identification. Mr. J ason Pietroski, Mr. Kevin Reine, Ms. Lindsey Green, and Dr. J ohn White assisted with sample collection and laboratory analysis. Mr. Frank Spilker assisted with data analysis and statistical tables. Mr. Mark Antwine provided invertebrate identification. The U.S. Army Corps of Engineers (USACE) New Orleans District provided logistical support throughout the project.

COL Bryan S. Green was Commander of ERDC, and Dr. David W. Pittman was the Director. 


\section{Acronyms and Abbreviations}

\begin{tabular}{|c|c|}
\hline ACNI & Acer nigrum \\
\hline ACRU & Acer rubrum \\
\hline ANOVA & Analysis of Variance \\
\hline $\mathrm{AOI}$ & Area of Interest \\
\hline BUMP & Beneficial Use of Dredged Material Program \\
\hline CELA & Celtis laevigata \\
\hline CH3D & Curvilinear Hydrodynamics in 3 Dimensions \\
\hline CHL & Coastal and Hydraulics Laboratory \\
\hline $\mathrm{dbh}$ & Diameter at Breast Height \\
\hline $\mathrm{DM}$ & Dredged Material \\
\hline DOER & Dredging Operations and Environmental Research \\
\hline $\mathrm{EAB}$ & Emergent Aquatic Bed \\
\hline EL & Environmental Laboratory \\
\hline ENC & Electronic Navigation Chart \\
\hline ERDC & Engineer Research and Development Center \\
\hline EWN & Engineering With Nature \\
\hline FRPE & Fraxinus pennsylvanica \\
\hline GDAL & Geospatial Data Abstraction Library \\
\hline GIS & Geographic Information System \\
\hline GIWW & Gulf Intracoastal Water Way \\
\hline GTRAN & General Transport \\
\hline HEC & Hydrologic Engineering Center \\
\hline $\mathrm{KCl}$ & Potassium Chloride \\
\hline
\end{tabular}




\begin{tabular}{|c|c|}
\hline LOI & Loss on Ignition \\
\hline $\mathrm{MBN}$ & Microbial Biomass Nitrogen \\
\hline MOCE & Morella cerifera \\
\hline MVN & New Orleans District \\
\hline $\mathrm{N}$ & Nitrogen \\
\hline $\mathrm{NH}_{4}-\mathrm{N}$ & Ammonium \\
\hline $\mathrm{NO}_{3}^{-}$ & Nitrate \\
\hline $\mathrm{NO}_{3}-\mathrm{N}$ & Nitrate Nitrogen \\
\hline NOAA & National Oceanic and Atmospheric Administration \\
\hline PLOC & Platanus occidentalis \\
\hline PODE & Populus deltoides \\
\hline QUNI & Ouercus nigra \\
\hline RMA & Resource Management Associates \\
\hline SANI & Salix nigra \\
\hline $\mathrm{SRP}$ & Soluble Reactive Phosphorous \\
\hline TADI & Taxodium distichum \\
\hline $\mathrm{TC}$ & Total Carbon \\
\hline TDN & Total Dissolved Nitrogen \\
\hline $\mathrm{TN}$ & Total Nitrogen \\
\hline $\mathrm{TP}$ & Total Phosphorous \\
\hline TRCE & Triadica cebifera \\
\hline USACE & U.S. Army Corps of Engineers \\
\hline USDA & U.S. Department of Agriculture \\
\hline USGS & U.S. Geological Survey \\
\hline WY & Water Year \\
\hline
\end{tabular}




\section{Unit Conversion Factors}

\begin{tabular}{|l|l|l|}
\hline Multiply & By & To Obtain \\
\hline bars & 100 & kilopascals \\
\hline feet & 0.3048 & meters \\
\hline hectares & $1.0 \mathrm{E}+04$ & square meters \\
\hline miles (nautical) & 1,852 & meters \\
\hline miles (U.S. statute) & $1,609.347$ & meters \\
\hline
\end{tabular}




\section{Executive Summary}

A multifactor ecosystem assessment of dredged material supported wetlands was conducted within the Atchafalaya River, Louisiana. Results indicate that the innovative use of dredged materials in a riverine environment supports wetland formation and expansion while providing habitat, hydrologic, and biogeochemical functions. The strategic placement of dredged materials in locations that mimic natural processes promotes additional ecological benefits, especially regarding wading bird and infaunal habitat, thus adhering to Engineering With Nature (EWN) principles. The multifactor approach improved the wetland assessment, allowing for a comprehensive ecosystem-level analysis of a diverse array of ecosystem components and functions. Sample locations included Island E, a traditional dredged material supported wetland island; Horseshoe Bend Island, a dredged material supported wetland island created using EWN processes; and Middle Island, a mature, naturally formed wetland island.

A multiple-ecosystem assessment was undertaken at Horseshoe Bend Island, including evaluation of (1) geomorphic evolution, (2) ecosystem classification and distribution, (3) floral communities, (4) avian communities, (5) aquatic invertebrates, (6) soils and biogeochemical activity, and (7) hydrodynamic and sediment transport processes. Results were compared to observations made at the other two sampling locations. Horseshoe Bend Island and Island E contained four distinct wetland classes while Middle Island contained only two. Horseshoe Bend Island exhibited the highest plant species richness (82 species; $85 \%$ native vegetation). Surveys of bird populations on Horseshoe Bend Island yielded a high number of breeding wading birds in dense, mixed-species nesting colonies, including 79\%juveniles, indicating that the island supports a productive nesting colony.

Both dredged material supported islands contained significantly higher amounts of fine particles and organic matter than Middle Island, resulting in significantly higher infaunal abundance. Further, both dredged material supported islands provide nutrient cycling functions, including estimated nitrogen removal rates of 1577- $1645 \mathrm{~kg} \mathrm{NO}_{3}-\mathrm{N} \mathrm{yr}^{-1}$, indicating the ability to improve water quality. Results of a Curvilinear Hydrodynamics in 3 Dimensions (CH3D) model proved strongly related to hydrological forcing. When linked with a General Transport (GTRAN) model, sediment transport rates indicated possible deposition toward the northern shore 
and erosion from the southern shore of Horseshoe Bend Island. Sedimentation rates remained elevated during the wet season with an estimated maximum volume transport rate of $9.66 \mathrm{~m} 3 / \mathrm{m} / \mathrm{s}$ and $0.71 \mathrm{~m} 3 / \mathrm{m} / \mathrm{s}$ as suspended and bedload sediments, respectively. 


\section{Introduction}

\subsection{Background}

The following section outlines Engineering With Nature (EWN) principles and describes the applicability of dredged material to support wetland ecosystems. The beneficial use of dredged material is consistent with EWN, a U.S. Army Corps of Engineers (USACE) initiative enabling more sustainable delivery of economic, social, and environmental benefits associated with water resources infrastructure (Bridges et al. 2014; Gerhardt-Smith and Banks 2014; EWN 2016). EWN concepts addressed through the current project include (1) the use of science and engineering to produce operational efficiencies supporting sustainable delivery of project benefits and (2) the use of natural processes to maximum benefit, thereby reducing demands on limited resources, minimizing the environmental footprint of projects, and enhancing the quality of project benefits.

The geographical extent of wetlands continues to decrease at national and regional scales, including major wetland losses across southern Louisiana (Barras et al. 2003; USACE 2004). Louisiana contains approximately $40 \%$ of the wetlands in the contiguous United States and continues to exhibit rapid wetland losses representing nearly $80 \%$ of the total wetland losses in the lower 48 states (Edwards and Proffitt 2003; Bourne 2000; Turner 1997; Day et al. 2007). Additionally, estimated forested wetland losses across the lower Mississippi Alluvial Valley exceed $74 \%$ with only 2.8 of an original 10 million ha remaining today (Gardiner and Oliver 2005; The Nature Conservancy 1992; King et al. 2006). Wetland losses have been accompanied by a decrease in wetland functions (J ohnston 1994; Bedford and Preston 1988).

Wetlands in southern Louisiana provide a number of ecosystem functions, including (1) the maintenance of floral and faunal habitat, (2) biogeochemical functions, and (3) hydrologic functions (Boesch et al. 1994; Zedler 2000; Llewellyn et al. 1996). Wetlands in the region provide important habitat for migratory waterfowl and forest songbirds (King and Keeland 1999; Twedt and Somershoe 2009). Wetland habitats also enhance invertebrate communities that sustain recreational and commercial fisheries, including shrimp (Engle 2011; Boesch and Turner 1984; Chesney et al. 2000). Biogeochemical functions in Atchafalaya River wetlands include 
nutrient cycling, carbon accumulation, and denitrification (Novitski et al. 1996; Bedford and Preston 1988). Specifically, Stern et al. (1991) and others demonstrated that wetlands in the region removed nitrate, soluble reactive phosphorus, and total suspended solids from the water column. The ability of wetlands to reduce nutrient loads in river waters has the capacity to improve water quality and decrease hypoxia in the Gulf of Mexico (Mitsch et al. 2001; Lindau et al. 2008; Rabalais et al. 1994). Additionally, wetlands across the region demonstrate high levels of carbon sequestration, impacting the greenhouse gas balance (Rabenhorst 1995; DeLaune and Pezeshki 2003). Southern Louisiana wetlands also provide a variety of hydrologic functions. For example, Wamsley et al. (2010) and others have investigated the ability of wetlands to reduce storm surge. Also, Costanza et al. (2008) identified significant relationships between wetland area and hurricane damage within the region.

In Louisiana, wetland distribution and functional losses have been linked to a lack of sediment inputs among other causes (e.g., development, agriculture and forestry, and flood control) (Day et al. 2007; Templet and Meyer-Arendt 1998). USACE conducts dredging activities to maintain navigation channels in the lower Atchafalaya River. Annual dredging projects within the lower Atchafalaya River produce over 9.9 million $\mathrm{m}^{3}$ of material at a cost of $\$ 30$ million dollars (Corbino 2014). These dredging activities remove sediment from navigation channels, which is then available for beneficial uses, including wetland creation and expansion (Boustany 2010).

\subsection{Objective}

The project objective was to demonstrate how dredged material can be used beneficially to nourish a naturally forming river island. Biology, ecology, geography, and hydrodynamics were examined to catalog the island's maturation for determining the effectiveness of this individual project in terms of restoring, creating, enhancing, and protecting the coastal Louisiana landscape, consistent with EWN principles.

\subsection{Approach}

The current study applies historical geospatial imaging and classification, hydrodynamic analysis, and a multifactor ecosystem assessment of dredged material supported wetlands located within the Atchafalaya River, 
Louisiana. Assessment factors include examination of (1) historical geospatial imaging and landmass classification, (2) ecosystem classification and geomorphology, (3) floral communities, (4) avian communities, (5) aquatic invertebrates, (6) soils and biogeochemical activity, and (7) hydrodynamic modeling of the study area. Initial field work at Horseshoe Bend Island (performed in August 2013; Berkowitz et al. 2014) provided a basis to conduct the current study. Following a description of the study area, separate sections address research methods and results regarding each factor. An analysis and discussion of findings is also provided along with opportunities for future research. 


\section{Study Area}

The study area is located at Horseshoe Bend, a segment of the Atchafalaya River and Bayous Chene, Boeuf, and Black Federal navigation channel located in the lower Atchafalaya River approximately $32 \mathrm{~km}$ south of Morgan City, LA (Figure 1). Although dredging of the navigation channel received original authorization in 1910, active maintenance dredging of Horseshoe Bend was not required until 1990 because natural channel depths exceeded authorized dimensions. Beginning in 1990 and proceeding thru 2013, 17 maintenance dredging events within this segment occurred at a return interval of 1 to 3 years with each event resulting in the removal of between 0.38 and 2.0 million $\mathrm{m}^{3}$ of shoal material (Figure 2).

Figure 1. Study location within the lower Atchafalaya River, St. Mary Parish, LA (indicated by the rectangle).

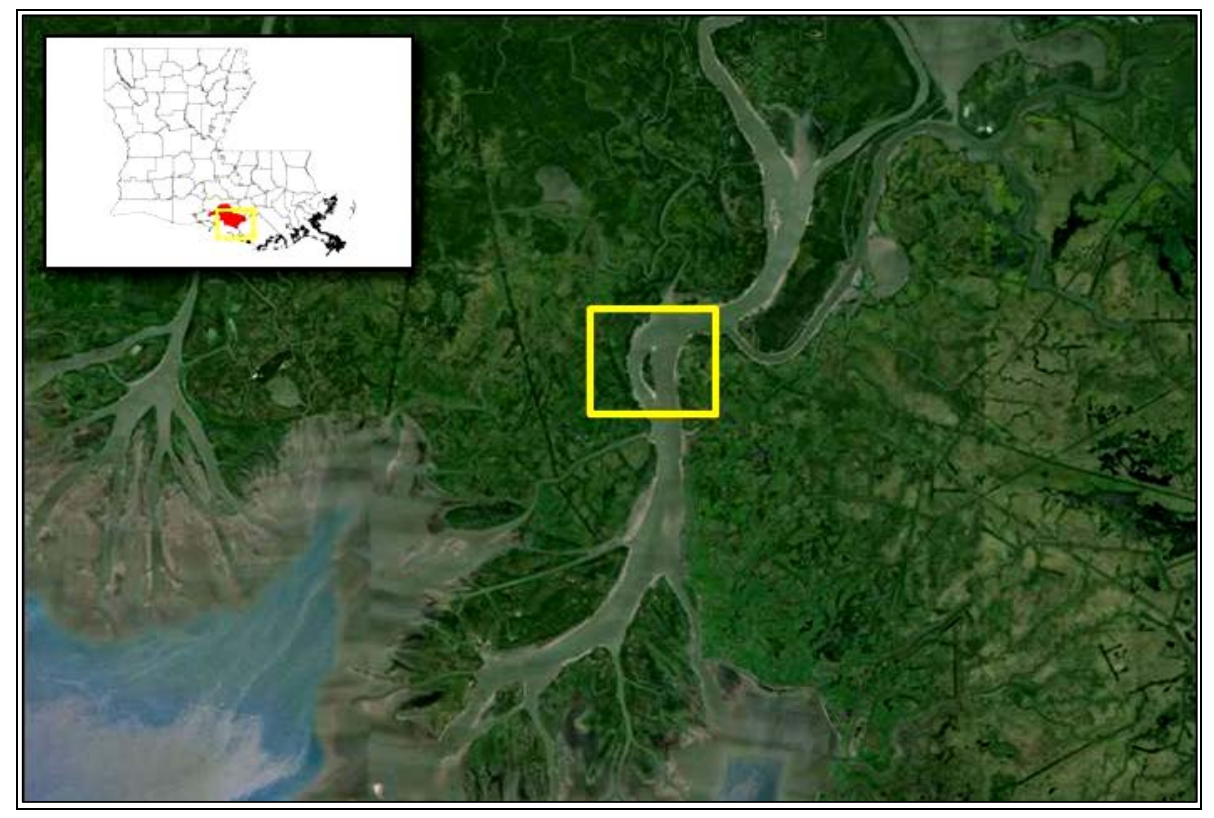


Figure 2. Dredged material placement history within the study reach between 1990 and 1999 (University of New Orleans 2002). Note the presence of Island E (rectang/e) near the top of the image; Horseshoe Bend Island (circle) was not present in 1999.

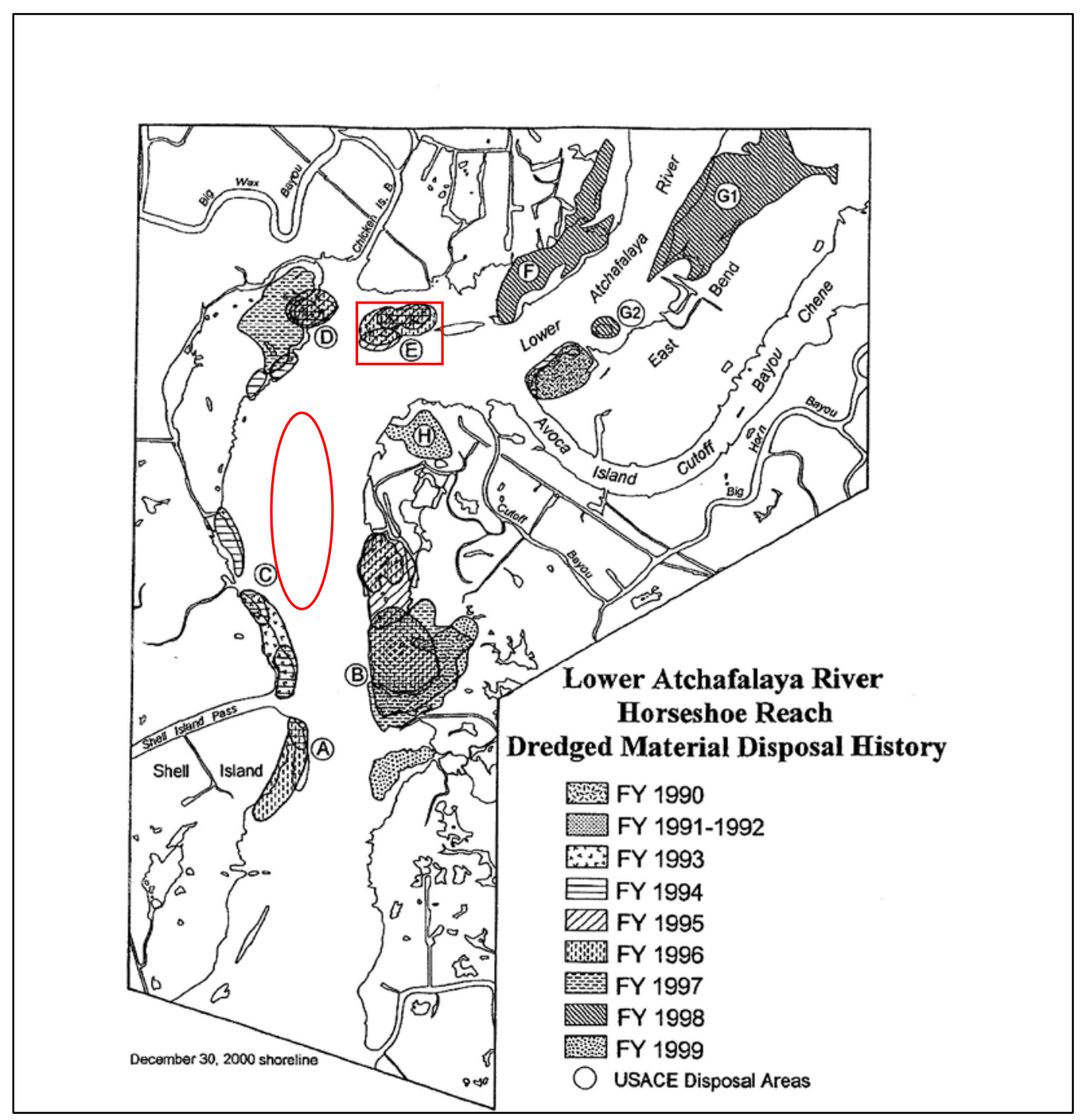

During the 1990s, placement of shoal material dredged from Horseshoe Bend occurred at eight wetland development sites located along the riverbank adjacent to the channel (Figure 2). These efforts resulted in the creation of 23 ha Island $\mathrm{E}$ during dredging events in 1995 and 1996. Capacity of these placement sites was nearly exhausted by 1999. Thus, to meet the anticipated disposal requirements for future channel maintenance, the USACE New Orleans District (MVN) evaluated three placement alternatives: (1) onverting the wetland development sites into upland disposal areas; (2) open-water placement of dredged material via a long-distance pipeline into the open waters of the Atchafalaya Bay; and (3) mounding material at mid-river open water 
placement sites within a 142 ha area immediately adjacent to the navigation channel and upriver of a small, naturally forming submerged shoal. Environmental and cost concerns precluded the selection of alternatives 1 and 2 . The third alternative was selected on a trial basis to investigate the impacts of mid-river placement on shoaling trends downriver of the site.

Beginning in 2002, strategic placement of the sediment dredged from Horseshoe Bend from the adjacent navigation channel occurred at the mid-river open water placement area. Placement of between 0.38 to 1.4 million $\mathrm{m}^{3}$ of sediment was conducted every 1 to 3 years, which influenced and contributed to the development of an approximately 35 ha mid-river island (Figures 3 and 4). The created island is referred to herein as Horseshoe Bend Island. To compare wetland conditions and functions across a range of locations, this study also selected a traditionally created dredged material island (i.e., Island E) less than $2.4 \mathrm{~km}$ north of Horseshoe Bend Island and a naturally formed wetland island (Middle Island) approximately $32 \mathrm{~km}$ north of the Horseshoe Bend. Middle Island was naturally formed during the mid-1970s and has persisted as a 142 ha island since that time.

Figure 3. Imagery displaying island location prior to dredged material (DM) placement and subsequent formation (1992 and 1998 images), establishment, and growth since strategic dredged material placement began in 2002. (Imagery provided by USACE MVN.)

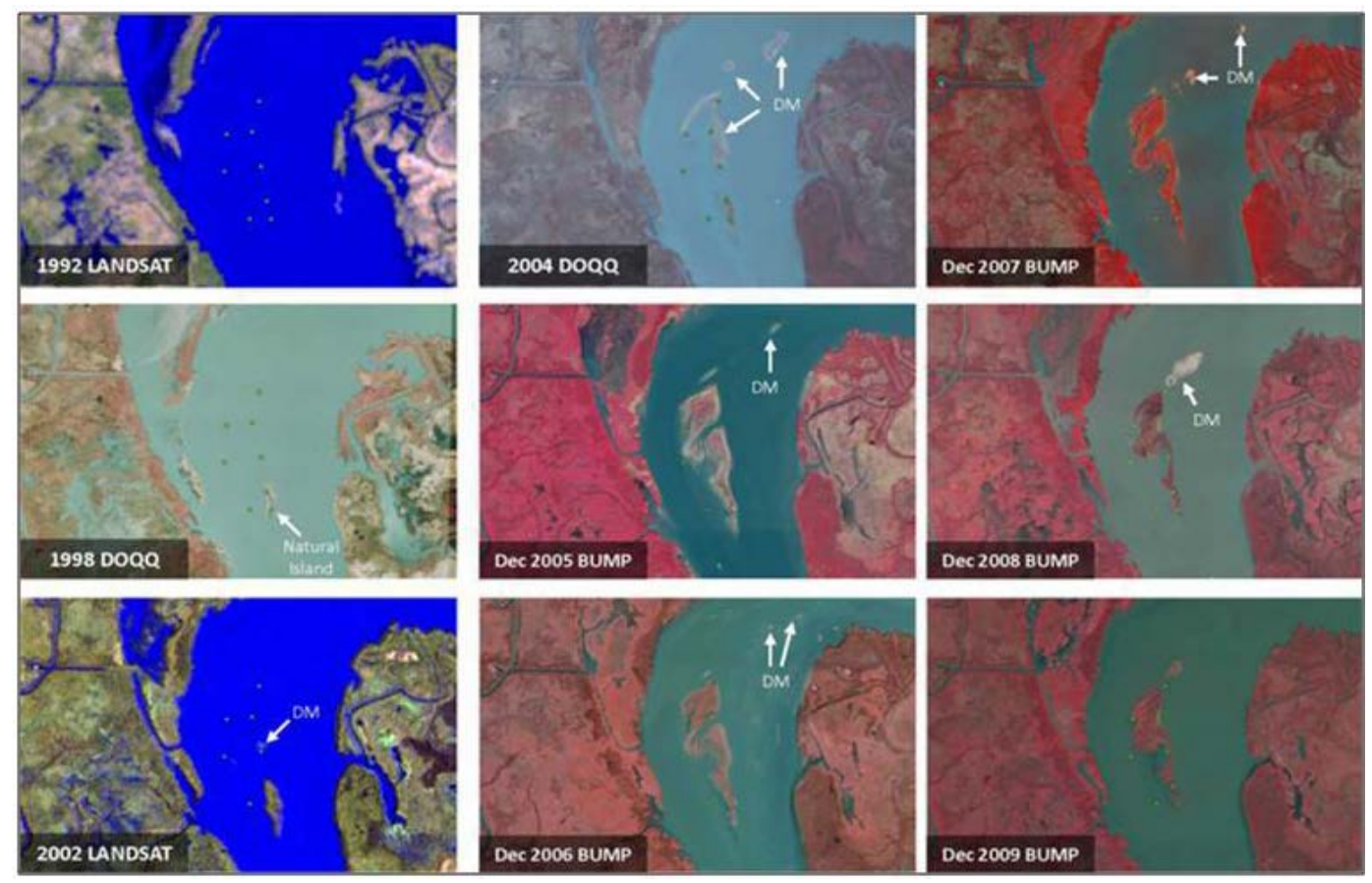


Figure 4. Horseshoe Bend Island, a 35 ha island supported by strategic dredged material placement. Note the small dredged material mound (circled) placed immediately upriver (north) of the island. Image dated 28 October 2012.

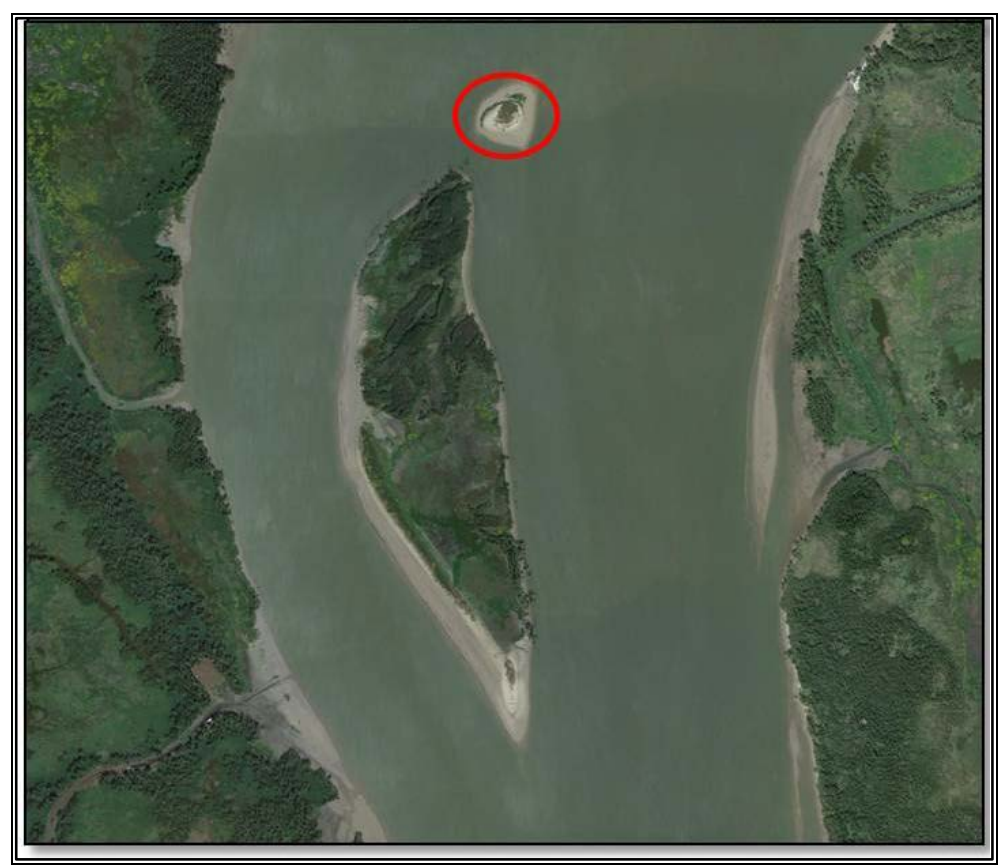




\section{Horseshoe Bend Island Image Analysis and Geomorphic Evolution}

\subsection{Introduction}

Under the USACE Beneficial Use of Dredged Material Program (BUMP), the MVN collects aerial photography for select dredge disposal areas on an annual basis. The imagery is used to monitor the environmental effects of dredge disposal activities. This imagery additionally allows for the quantification of the island size and geomorphology, supporting ecosystem classification efforts as described in Section 4. Using this information, the MVN analyzed the geomorphic development of Horseshoe Bend Island from 2007 to 2014.

\subsection{Methods}

Since 2007, the imagery has been collected in a digital format and loaded as a mosaic into the Geospatial Data Abstraction Library (GDAL), allowing easy access for visualization and analysis. Resolution of the imagery is generally $0.61 \mathrm{~m}$, which is sufficient to distinguish land, water, and vegetation. The GDAL is a C library frequently used for raster analysis. GDAL provides an abstraction layer for input-output operations on numerous raster formats, allowing a user to write a program to work with many different raster sources without a substantial code rewrite. ArcGIS software was used to create the maps and perform analysis of the above-water extent of Horseshoe Bend Island. ArcGIS includes a middleware product that allows a database such as Oracle to store very large raster datasets, such as the BUMP series. Imagemagick is a Clibrary with command-line applications to manipulate images; it was also used during the image analysis process.

The analysis of Horseshoe Bend Island examined available imagery to differentiate between landscape features. Using ArcGIS software, an area- ofinterest (AOI) rectangle was created that covered the analysis area. Band 3 from each of the available BUMP imagery datasets was clipped to the AOI. A script was developed to automate the process. Even though there can be substantial differences in pixel values of the same land-cover types from year to year in the BUMP imagery, the objective was to develop a quick, consistent workflow that would be understandable and provide the project team with an estimate of the island's location and general growth trends. 
A region-growing algorithm was implemented as the core component of the analysis work flow. The program was written in C++ using the GDAL library for input-output operations on the imagery. During initialization, a series of real-world coordinates from known water locations were mapped to pixel coordinates and added to a queue. During each iteration of the algorithm, the head pixel was removed from the queue; and the values of each of its eight neighboring pixels were subtracted from the head pixel's value and compared to a threshold value. Neighboring pixels with a difference lower than the threshold signified that the pixel was similar to the head pixel. These similar pixels were appended to the queue, and the algorithm proceeded through the next iteration. A check was added to ensure that a pixel was compared only once in this manner. The algorithm was completed when the queue was emptied.

To improve the results of the algorithm, a number of preprocessing and post-processing steps were required. Because pixels representing water are typically surrounded by other pixels representing water and the distinction between values that are not water are inconsequential for this analysis, a filter was applied to remove noise from the imagery. Input imagery was processed in ArcGIS through a series of Majority Filters, which replace a pixel value with the mode of the eight surrounding neighbors to bring water values closer to each other in value and to reduce the required threshold for the region growing algorithm. The output raster was converted into polygons using the ArcGIS geoprocessing library based on contiguous land and water regions. An area was calculated for each region. The sizes of the output polygons classified as land were used to determine whether the polygon was actual land or noise. Parameters were determined for the 2012 imagery and were applied to the prior years to generate the land-water geomorphic analysis.

\subsection{Results and conclusions}

Using a combination of automated analysis and manual editing, developers were able to distinguish general geomorphic features for the years 2007 to 2014 based on available BUMP imagery (Figure 5). Additionally, yearly results were compared to the source BUMP imagery collected in 2012. The trend points to a general net increase in total land acreage over time, representing the geomorphic evolution of the Horseshoe Bend Island, with the island increasing from 26 to 35 ha from 2007 to 2014 (Figure 6). 
Figure 5. Land-water geomorphology for Horseshoe Bend Island for years 2007 through 2012, with 2012 representing the base condition. The areas in orange indicate the algorithm-estimated aerial land cover detected during each of the years examined.

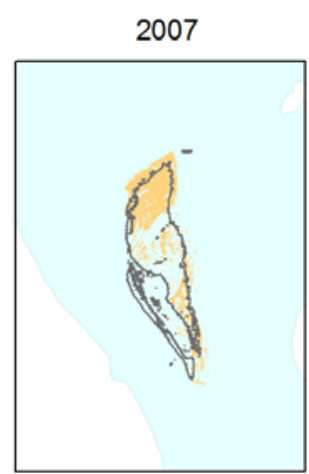

2010

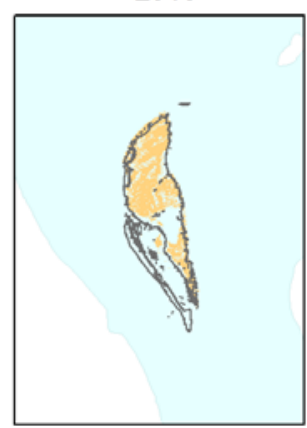

2008

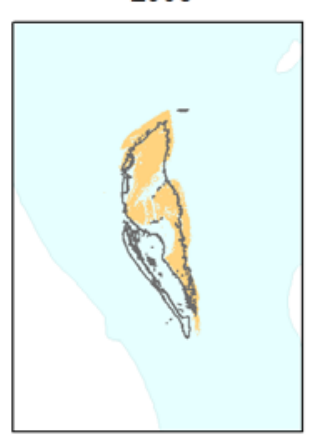

2011

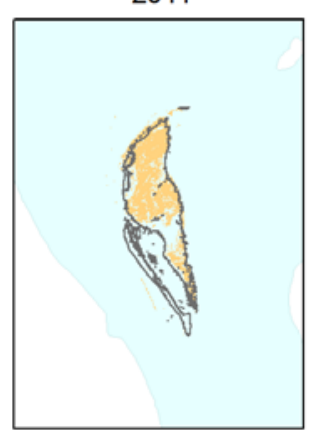

2009

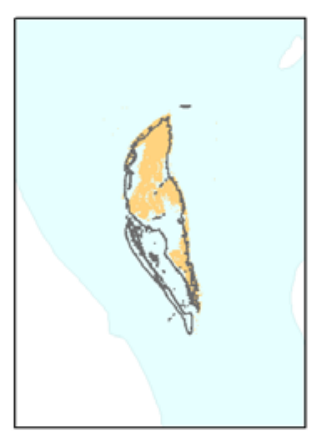

2012

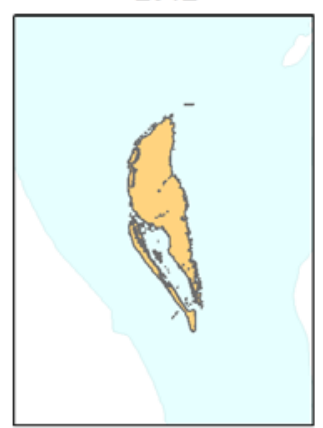

Figure 6. BUMP images of Horseshoe Bend Island (a) 2008, (b) 2009, (c) 2010, (d) 2011, (e) 2012, (f) 2013, and (g) 2014.

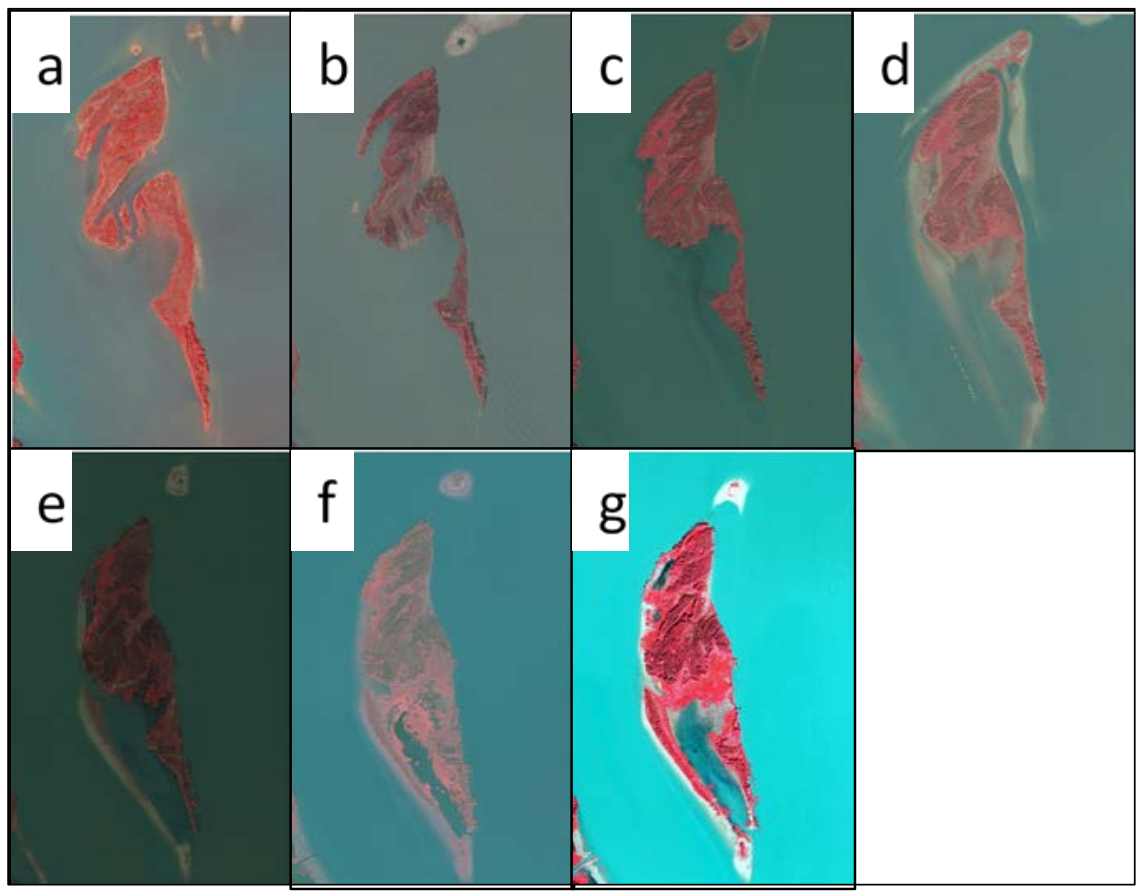


It is possible for algorithms to identify a wooded area from an aerial photo but not the level of maturity of the trees within the wooded area, which has an impact on ecosystem classification and mapping. Similarly, it remains difficult for algorithms to determine the difference between open water and non-wooded land when the water is covered by floating or other aquatic vegetation species. Despite these limitations, polygonal output formats facilitate future additions and revisions because a human operator can override specific outputs of the algorithm. Additionally, geomorphic analysis can be applied to the time period before 2008; although the BUMP imagery remains in hard copy format, it can be used in the future to establish more of the early history of the island's landscape geomorphology. 


\section{Ecosystem Classification and Distribution}

\subsection{Wetland classification}

Classifying wetlands into ecosystem types has been widely applied to ecosystem assessments and leads to decreased variability when making comparisons across both large and small spatial scales (Brinson 1993; Brinson et al. 1994; Smith et al. 2013). To classify the wetlands within the study area, visits were conducted during August 2013 (Berkowitz et al. 2014), July 2014, and August 2014. Based on field observations; GIS (geographic information system) coordinate data collected onsite; and interpretation of aerial photographs, GIS files, and other off-site sources, each wetland community type was delineated. The Classification of Wetlands and Deepwater Habitats of the United States (Cowardin et al. 1979) formed the basis of the wetland classification scheme used. The results of the ecosystem classification effort reveal four distinct ecological communities occurring within the study area (Table 1; Figures 7-9). A brief generic description of each community is presented below, consistent with the classification system developed by Cowardin et al. (1979). Specific elements (e.g., vegetation, fauna, soils, etc.) of the multifactor wetland assessment are provided in subsequent sections.

Table 1. Areal extent of wetland classification types within each island studied. Note that all wetland area created at Horseshoe Bend Island and Island E resulted from dredged material placement; Middle Island formed naturally.

\begin{tabular}{|l|c|c|c|}
\hline \multicolumn{1}{|c|}{ Wetland Class } & Horseshoe Bend Island & Island E & Middle Island \\
\hline Forested & $10.2(29)$ & $6.9(29)$ & $127.3(89)$ \\
\hline Scrub Shrub & $1.3(4)$ & $0.8(3)$ & $0.0(0)$ \\
\hline Emergent & $4.0(11)$ & $2.0(9)$ & $14.4(10)$ \\
\hline Aquatic Bed & $19.1(55)$ & $13.5(58)$ & $0.0(0)$ \\
\hline Total & 35.0 & 23.1 & 141.7 \\
\hline
\end{tabular}

Units are in hectares with percentages in parenthesis. 
Figure 7. Ecosystem classification results at (a) Horseshoe Bend Island, $(b)$ Island E, and (c) Middle Island. Note that palustrine forested areas are shown in green, aquatic bed features appear in blue, scrub-shrub wetlands are in yellow, and emergent wetlands are denoted in purple.

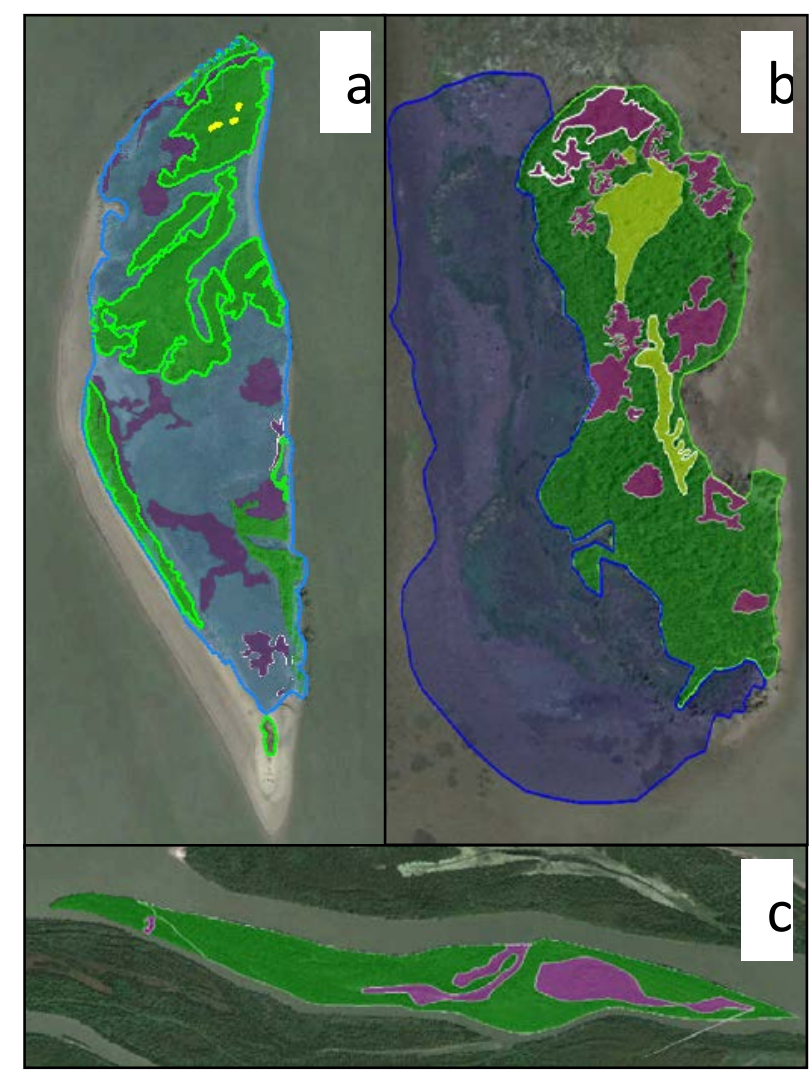

Figure 8. Average elevation of wetland classes identified at Horseshoe Bend Island and Island E. Error bars represent standard error of the mean. Wetland classes with a different letter had statistically different elevations.

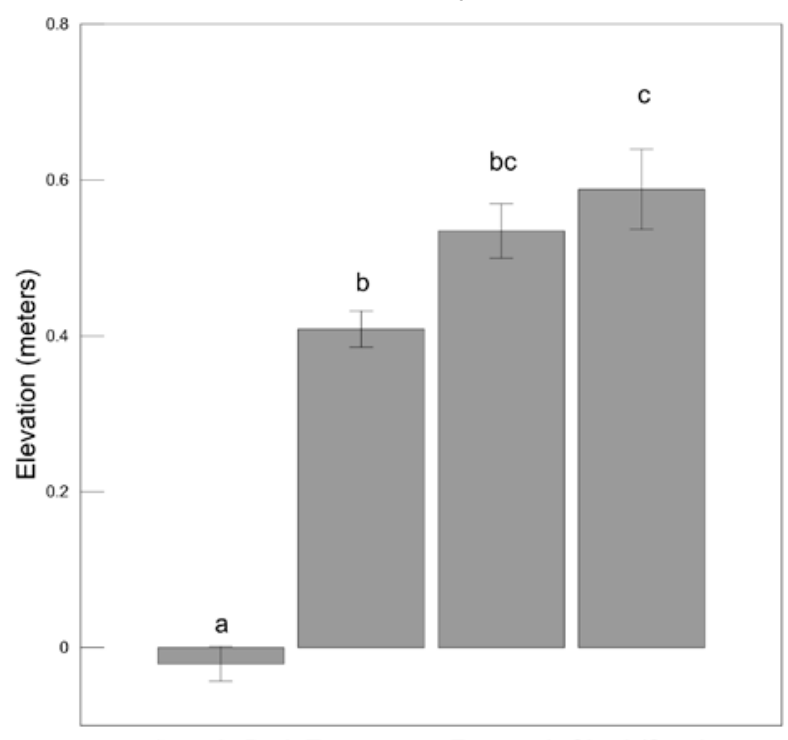

Aquatic Bed Emergent Forested Shrub/Scrub 
Figure 9. Habitat map of the Horseshoe Bend portion of the Atchafalaya River in 2001 (University of New Orleans 2002). The circle indicates the location of Island E; the square outlines Horseshoe Bend Island and a small dredged material feeder mound to the north. Note that the authors identified forested, shrub/scrub, and marsh (i.e., emergent) wetland classes.

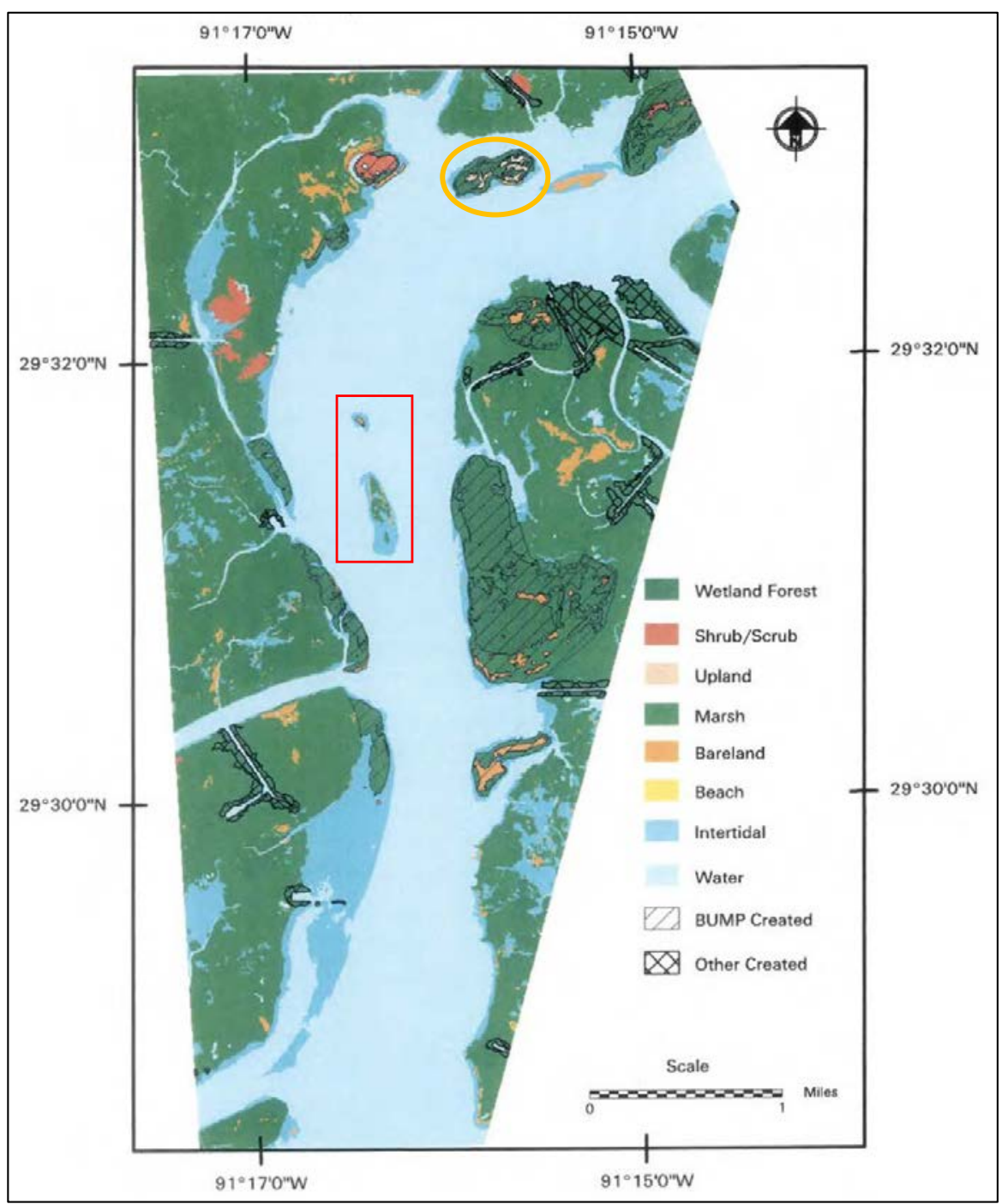

Palustrine broadleaf forested wetlands consist of temporarily flooded zones exhibiting established woody vegetation with an overstory approximately more than $6.1 \mathrm{~m}$ in height. These wetlands receive intermittent exposure to freshwater inputs ( $<0.05 \%$ salinity) from groundwater saturation, overbank, and backwater flooding regimes. The frequency and duration of flooding varies on both local and regional scales. Common dominants include species such as ashes (Fraxinus pennsylvanica and F. nigra), black gum (Nyssa sylvatica), tupelo gum (N. aquatica), swamp white oak (Quercus bicolor), overcup oak (Q. lyrata), and willow (Salix spp.). Wetlands in this subclass generally occur on mineral soils or highly 
decomposed organic soils. Palustrine broadleaf forested wetlands occur within the most stable, established, and highest-elevation portions of the island, representing the most mature and structurally complex community type observed.

Palustrine broadleaf scrub-shrub wetlands consist of temporarily flooded zones exhibiting established woody vegetation less than $6.1 \mathrm{~m}$ in height. These wetlands receive intermittent exposure to freshwater inputs $(<0.05 \%$ salinity) from groundwater saturation, overbank, and backwater flooding regimes. The frequency and duration of flooding varies on both local and regional scales. The species include true shrubs, young trees, and trees or shrubs that are small or stunted because of environmental conditions. Scrub-shrub wetlands may represent a successional stage leading to forested wetland, or they may be relatively stable communities. They represent one of the most widespread classes in the United States. Dominance types include sea-myrtle (Baccharis halimifolia), marsh elder (Iva spp.), alders (Alnus spp.), willows (Salix spp.), buttonbush (Cephalanthus occidentalis), red osier dogwood (Cornus stolonifera), honeycup (Zenobia pulverulenta), spirea (Spiraea douglasii), bog birch (Betula pumila), and young trees of species such as red maple (Acer rubrum) or black spruce (Picea mariana). Wetlands in this subclass generally occur on mineral soils or highly decomposed organic soils. Palustrine broadleaf scrub-shrub wetlands occur within less stable, geomorphically younger, and moderateelevation portions of the island, representing the second-most mature and structurally complex ecosystem type observed.

Palustrine persistent emergent wetlands consist of seasonally flooded herbaceous areas characterized by erect, rooted, herbaceous hydrophytes, excluding mosses and lichens. This vegetation is present for most of the growing season in most years. These wetlands usually remain dominated by perennial plants. Palustrine persistent emergent wetlands contain a vast array of grasslike plants such as cattails (Typha spp.), bulrushes (Scirpus spp.), saw grass (Cladium jamaicense), and sedges (Carex spp.) and true grasses such as reed (Phragmites australis), manna grasses (Glyceria spp.), slough grass (Beckmannia syzigachne), and whitetop (Scolochloa festucacea). There is also a variety of broadleaved persistent emergents such as purple loosestrife (Lythrum salicaria), dock (Rumex mexicanus), waterwillow (Decodon verticillatus), and many species of smartweeds (Polygonum spp.). Palustrine persistent emergent wetlands occur within the transition zones between forest and scrub-shrub wetlands and aquatic bed 
features. Emergent-dominated ecosystems represent dynamic ecosystems with homogenous vegetative structure.

Palustrine aquatic bed wetlands consist of wetlands and deepwater habitats dominated by plants that grow principally on or below the surface of the water for most of the growing season in most years. Water regimes include irregularly exposed, regularly flooded, permanently flooded, intermittently exposed, semipermanently flooded, and seasonally flooded. Aquatic beds represent a diverse group of plant communities that require surface water for optimum growth and reproduction. They are best developed in relatively permanent water or under conditions of repeated flooding. The plants are either attached to the substrate or float freely in the water above the bottom. Rooted vascular aquatic plants occur at all depths within the photic zone. They often occur in sheltered areas where there is little water movement. Typical inland plants include pondweeds, horned pondweed (Zannichellia palustris), ditch grasses (Ruppia spp.), wild celery (Apium graveolens), and waterweed (Elodea spp.). Some of the rooted vascular species are characterized by floating leaves. Typical dominants include water lilies (Nymphaea spp.; Nuphar spp.), floating-leaf pondweed (Potamogeton natans), and water shield (Brasenia schreberi). Plants such as yellow water lily (Nuphar luteum) and water smartweed (Polygonum amphibium), which may stand erect above the water surface or substrate, may be considered either emergent or rooted vascular aquatic plants, depending on the life form adopted at a particular site. Beds of floating vascular plants occur mainly in the Palustrine system. The plants float freely either in the water or on its surface. Dominant plants that float on the surface include duckweeds (Lemna spp.; Spirodela spp.), water lettuce (Pistia stratiotes), and water hyacinth (Eichhornia crassipes). Palustrine aquatic bed wetlands occur at the lowest island elevations.

\subsection{Ecosystem distribution}

As depicted in Figures 7- 9 and Table 1, Horseshoe Bend Island and Island E each contain all four of the wetland classes listed above (forested, scrubshrub, emergent, and aquatic bed). Conversely, Middle Island consists of only forested and emergent areas. As a result, Middle Island exhibits lower habitat diversity despite being substantially larger than the other two study areas. Notably, the strategic placement of dredged materials resulted in the creation of four distinct wetland classes. 
The wetland class distributions result from a number of factors, including elevation gradients with aquatic bed and emergent habitats developing in low-lying, more frequently flooded areas while forested and scrub-shrub communities become established in higher topographic locations. Examining elevation data from Horseshoe Bend Island and Island E, wetland class elevations showed statistically significant differences ( $\mathrm{df}=29 ; \mathrm{F}=24.62$; $\mathrm{P}<0.001$ ) with aquatic bed habitats occurring below the river surface, emergent wetlands occurring in slightly elevated positions, followed by forested and shrub scrub wetlands (Figure 8).

For context, this study examined the results of two other studies conducted at larger spatial scales. The University of New Orleans (2002) made wetland determinations across an approximate $70 \mathrm{~km}^{2}$ area (Figure 9). That study reported similar wetland classification results as presented herein (Figure 9; Table 2; Table 3), indicating the presence of forested and scrub-shrub wetland types and marsh and intertidal wetlands (i.e., emergent and aquatic bed wetlands). Stedman and Dahl (2008) and Engle (2011) presented data at a much larger spatial scale, encompassing the Gulf of Mexico from Texas to Florida. They also classified wetlands in terms of palustrine emergent, forested, and scrub (i.e., scrub-shrub) wetlands. The results of the current study compare well with the habitat distributions provided by the University of New Orleans (2002). In that study, freshwater marsh habitat (i.e., emergent aquatic bed) accounted for $67 \%$ of the natural wetland area surveyed. Our results indicate that $51 \%$ and $58 \%$ of the dredged material created habitat occurs as emergent aquatic bedforms at Horseshoe Bend Island and Island E, respectively. Similarly, the University of New Orleans (2002) study reported that forested wetlands occupied 28\% of the natural landscape; Horseshoe Bend Island and Island $\mathrm{E}$ each contained $29 \%$ forested wetlands. Finally, the University of New Orleans (2002) reported 1.3\% scrub-shrub wetlands in a natural setting; our findings indicate $0.9 \%$ scrub-shrub areas on the dredged material supported islands.

In summary, the dredged material supported islands exhibited a variety of ecological classes and distinct habitat types. The observed distribution of ecosystem classes corresponds with the findings reported in other studies. Examining landscape characteristics and geomorphology represents an important component contributing to the multifactor-assessment approach. 
Table 2. Habitat classification changes (hectares) of Horseshoe Bend Island between 1985 and 2001. (Adapted from University of New Orleans [2002].)

\begin{tabular}{|l|c|c|c|}
\hline \multicolumn{1}{|c|}{ Habitat Type } & 1985 & 2001 & Change 1985-2001 \\
\hline Natural Fresh Marsh & 1023 & 916 & -106 \\
\hline Natural Upland & 0 & 0.4 & -2.9 \\
\hline Natural Scrub-Shrub & 19.6 & 16.7 & 253 \\
\hline Natural Forested Wetland & 130 & 383 & 41.4 \\
\hline Natural Bare Land & 0 & 41.4 & 184 \\
\hline Total Natural Habitats & 1173 & 1358 & 2.7 \\
\hline Other-Made Fresh Marsh & 0 & 2.7 & -5.1 \\
\hline Other-Made Forested Wetland & 80.9 & 75.8 & 0.2 \\
\hline Other-Made Bare Land & 0 & 0.2 & -2.1 \\
\hline Total Other-Made Habitats & 80.9 & 78.8 & 131 \\
\hline BUMP-Made Marsh & 0 & 131.4 & 3.3 \\
\hline BUMP-Made Upland & 0 & 3.3 & 6.0 \\
\hline BUMP-Made Shrub/scrub & 0 & 6.0 & 112 \\
\hline BUMP-Made Forested Wetland & 0 & 112 & 16.5 \\
\hline BUMP-Made Bare Land & 0 & 16.5 & 0.6 \\
\hline BUMP-Made Beach & 0 & 0.6 & 270 \\
\hline Total BUMP-Made Habitats & 0 & 270 & 453 \\
\hline Habitat Total & 1254 & 1707 & \\
\hline
\end{tabular}

Table 3. Estimated area (hectares) of estuarine and palustrine wetlands along the Gulf of Mexico. (Adapted from Stedman and Dahl [2008] and Engle [2011]).

\begin{tabular}{|l|c|c|c|}
\hline \multicolumn{1}{|c|}{ Wetland Class } & $\mathbf{1 9 9 8}$ & $\mathbf{2 0 0 4}$ & Change 1998-2004 \\
\hline Estuarine Emergent & 982,969 & 965,127 & $-17,842$ \\
\hline Estuarine Shrub & 274,838 & 274,296 & -542 \\
\hline Palustrine Emergent & $1,124,913$ & $1,104,812$ & $-20,101$ \\
\hline Palustrine Forested and Shrub & $3,744,884$ & $3,604,418$ & $-140,466$ \\
\hline Total & $6,127,604$ & $5,948,652$ & $-178,952$ \\
\hline
\end{tabular}




\section{Floral communities}

\subsection{Introduction}

Vegetation plays a major role in the ecosystem functions associated with wetlands in the lower Atchafalaya River. The diversity of floral communities in the region provides habitat for a variety of terrestrial, aquatic, and avian species (J ohnson et al. 1985; Castellanos and Rozas 2001). Additionally, vegetated wetlands stabilize river sediments, allowing for accretion and land-building to occur. Van Heerden and Roberts (1980), Shaffer et al. (1992), and others have focused on the floral establishment, succession, and sustainment; and Faulkner and Poach (1996) compared vegetation between natural and dredged material supported islands in the region. However, few studies examine vegetative characteristics between wetland islands established using different techniques (i.e., natural establishment, traditional dredged material placement, and non-traditional dredged material placement). As a result, the following sections provide a basis for comparison across wetland island types, a contributing element of the multifactor ecosystem assessment.

\subsection{Methods}

All vegetation sampling occurred in August 2013 and August 2014. Vegetation sampling included quantification of dominant species within each distinct wetland class (forested, scrub-shrub, emergent, and aquatic bed). Sample-plot selection examined representative areas within each of the ecosystem classes; a randomized sampling design remains beyond the scope of the current assessment. Several variables were measured within each wooded area sampled, including (1) the identification of dominant overstory species; (2) stem counts of overstory trees within 0.04 ha plots; (3) measurements of shrub-sapling stem density (i.e., woody stems less than $10 \mathrm{~cm}$ in diameter at breast height (dbh) and greater than $1.2 \mathrm{~m}$ tall) within two nested 0.004 ha subplots; and (4) estimates of herbaceous and woody vegetation ground cover less than or equal to $1.4 \mathrm{~m}$ within four representative $1 \mathrm{~m}^{2}$ subplots (Figure 10). A comprehensive list of all plants observed was developed (Appendix A). Plants were identified to species or lowest taxonomic level possible with nomenclature following the U.S. Department of Agriculture (USDA) PLANTS Database (NRCS 2013). On Horseshoe Bend Island, vegetation sampling occurred using seven plots in forested, scrub-shrub, and emergent wetland areas (Figure 9). There were 
13 sample plots similarly located on Island E, and 14 sample plots were established on Middle Island.

Figure 10. Vegetation sampling scheme used for characterize forested, scrub-shrub, and emergent wetland habitats.

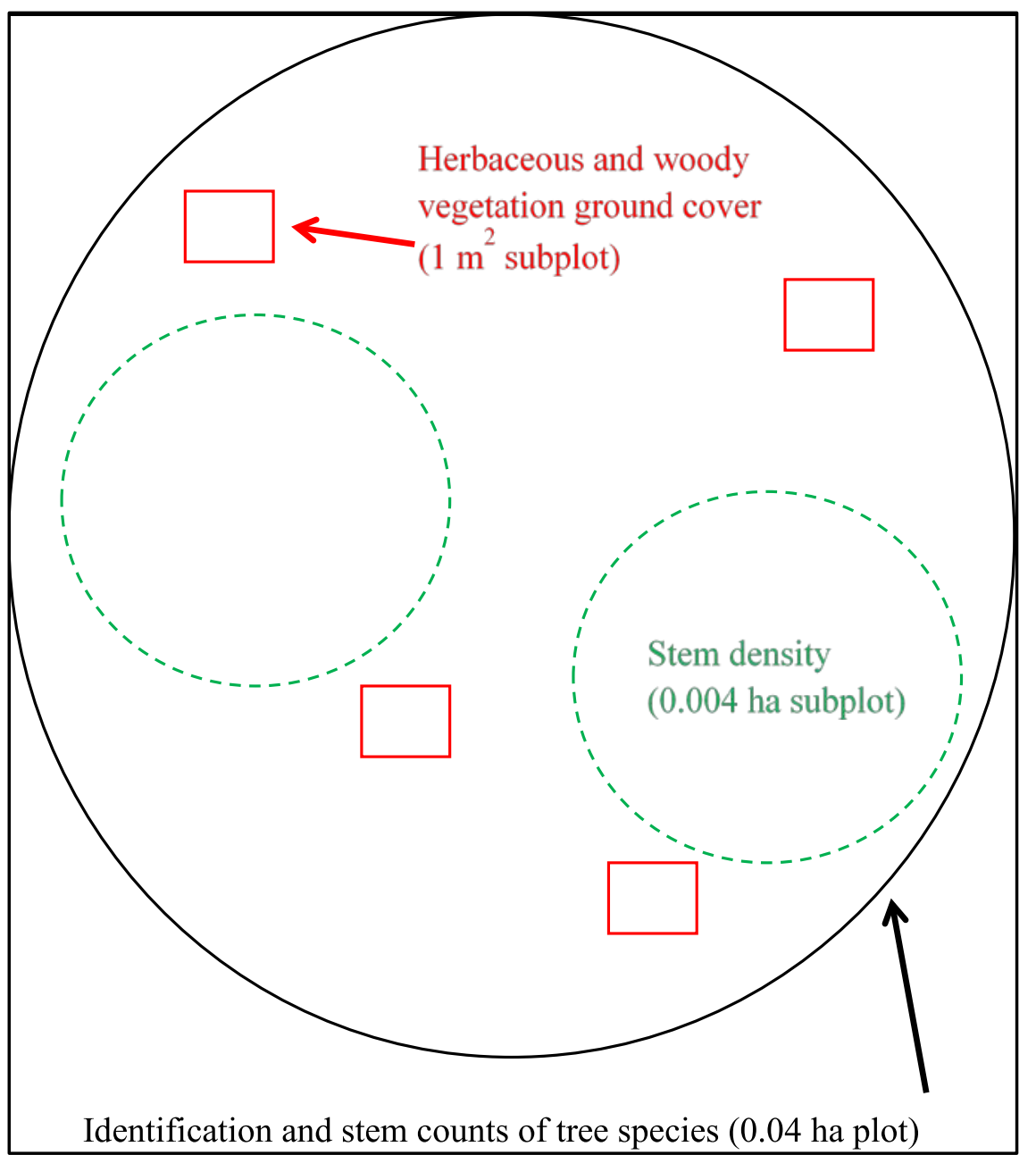

Vegetation sampling also occurred within aquatic bed areas. Variables measured at each sample point included an ocular estimation of percent cover of herbaceous and woody vegetation and estimates of percent cover of any free-floating or visibly submerged aquatic species (USACE 2010). Additionally, all plants observed within floating bed environments adjacent to the island were identified or collected for further identification in the lab. All specimens were identified to species, when possible, to provide a comprehensive baseline survey of all observed herbaceous and woody flora. Seven aquatic bed sample points were located on Horseshoe Bend Island, and five aquatic bed sample points were located on Island $\mathrm{E}$. 
Aquatic bed wetlands were not present at Middle Island at the time of sampling.

\subsection{Results}

\subsubsection{Horseshoe Bend Island}

Forested zones occupied approximately 12 ha of the Horseshoe Bend Island (Figures 7 and 11; Table 4). The majority of the forested areas displayed younger stand ages representing 10.5 ha while the older portions of the forest represented approximately $1.3 \mathrm{ha}$. Both of these forest wetland habits remained disproportionately dominated by black willow (Salix nigra) with eastern baccharis (Baccharis halimifolia) and common elderberry (Sambucus nigra canadensis) frequently observed as codominants. Other infrequently observed codominants included annual marsh elder (Iva annua) and red mulberry (Morus rubra). The average diameter of woody stems within well-established portions of the island was $12.5 \mathrm{~cm}$ $\mathrm{dbh}$, ranging from 5 to $20 \mathrm{~cm}$ dbh. Total tree density per hectare ranged from 1500 to 17,325 woody stems, resulting in varying amounts of ground cover across all forested sites (Table 4). The average tree height was $6 \mathrm{~m}$ across all plots measured with a maximum height of approximately $10 \mathrm{~m}$.

Figure 11. A forested wetland sample location on Horseshoe Bend Island.

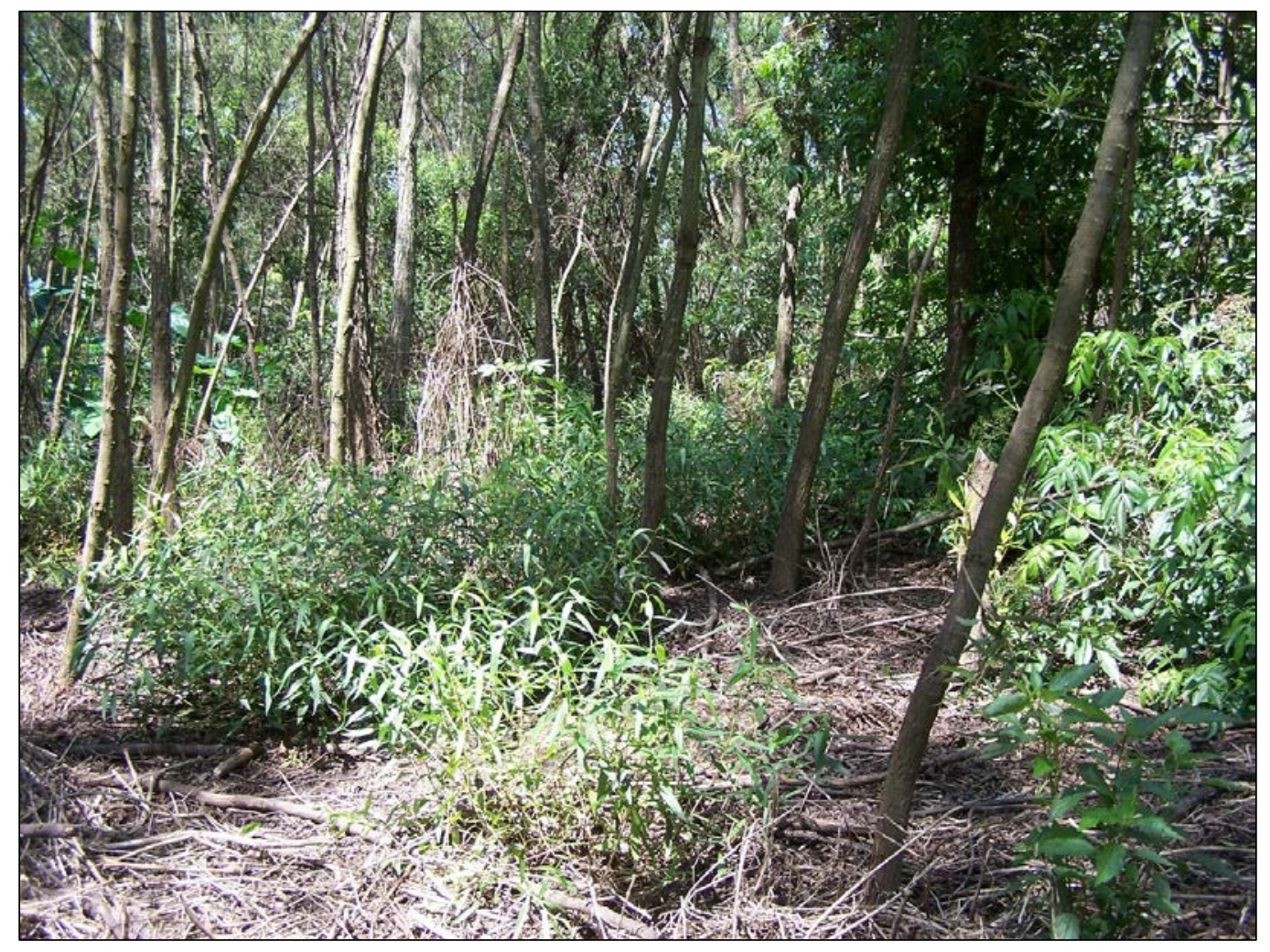


Table 4. Vegetation summary for wooded areas of Horseshoe Bend Island. Data include the number of trees within each sample plot, dominant tree species, tree density, shrub-sapling density, ground vegetation within each sample plot, and average percent ground cover.

\begin{tabular}{|c|c|c|c|c|c|c|c|c|c|}
\hline \multirow[b]{3}{*}{ Site } & \multirow{3}{*}{$\begin{array}{l}\text { Tree } \\
\text { Stem } \\
\text { Count }\end{array}$} & \multirow{3}{*}{$\begin{array}{l}\text { Dominant } \\
\text { Species }\end{array}$} & \multirow{3}{*}{$\begin{array}{l}\text { Tree Density } \\
\text { (stems/ha) }\end{array}$} & \multirow{3}{*}{\begin{tabular}{|} 
Sapling Stem \\
Density \\
(stems/ha)
\end{tabular}} & \multirow{2}{*}{\multicolumn{4}{|c|}{$\begin{array}{c}\text { Ground Vegetation } \\
\text { Cover (\%) }\end{array}$}} & \multirow{3}{*}{$\begin{array}{l}\text { Ground } \\
\text { Cover } \\
(\%)\end{array}$} \\
\hline & & & & & & & & & \\
\hline & & & & & 1 & 2 & 3 & 4 & \\
\hline 1 & 287 & SANI $^{*}$ & 7175 & 125 & 35 & 20 & 30 & 40 & 31.3 \\
\hline 2 & 225 & SANI & 5625 & 0 & 25 & 30 & 10 & 15 & 20 \\
\hline 3 & 693 & SANI & 17325 & 0 & 30 & 65 & 60 & 40 & 48.8 \\
\hline 4 & 472 & SANI & 11800 & 0 & 0 & 0 & 10 & 10 & 5 \\
\hline 5 & 370 & SANI & 9250 & 0 & 0 & 0 & 25 & 40 & 16.3 \\
\hline 6 & 60 & SANI & 1500 & 750 & 0 & 5 & 0 & 10 & 3.8 \\
\hline 7 & 298 & SANI & 7450 & 0 & 35 & 5 & 10 & 5 & 13.8 \\
\hline
\end{tabular}

* Salix nigra

The herbaceous layer was diverse both within and among the younger- and older-aged stands, with clear distinctions of understory conditions by age class not readily observed. However, across both stand types, consistent patterns of understory cover varied from densely aggregated clumps of vegetation less than $1 \mathrm{~m}$ in height (e.g., cocoyam [Colocasia esculenta]) to extensive ground cover of invasive torpedo grass (Panicum repens), smartweed (Polygonum spp.), or invasive alligatorweed (Alternantherea pholoxeroides). On the highest elevational areas, a pronounced abundance of dogfennel (Eupatorium capillifolium) was observed, with a distinct absence of coco-yam. Stiff dogwood (Cornus foemina) was found only in the higher elevation areas located on the southeast portion of the island. Additionally, black willow, common elderberry sprouts, and peppervine (Ampelopsis arborea) were frequently encountered. Less commonly observed, but scattered throughout both stand types, were buttonbush (Cephalanthus occidentalis), climbing hempvine (Mikania scandens), whorled marsh pennywort (Hydrocotyle verticillata), smallspike false nettle (Boehmeria cylindrica), flatsedge (Cyperus spp.), goldenrod (Solidago spp.), hairypod cowpea (Vigna luteola), broadleaf cattail (Typha latifolia), invasive Chinese tallowtree (Triadica sebifera), rosemallow (Hibiscus lasiocarpos), and broadleaf arrowhead (Sagittaria latifolia). The unvegetated areas of the ground throughout the island exhibited small-sized downed dead wood deposited during flooding events. Appendix A provides a comprehensive plant species list. 
On Horseshoe Bend Island, dominant aquatic bed wetland species included common water hyacinth (Eichhornia crassipes [Mart.] Solms), alligatorweed (Alternantherea philoxeroides [Mart.] Griseb.), water spangles (Salvinia minima Baker), common duckweed (Lemna minor L.), and primrose-willow (Ludwigia spp.) (Figure 12; Table 5). Several invasive species were observed during the aquatic bed wetland survey (Appendix A).

Figure 12. An aquatic bed wetland sample location on Horseshoe Bend Island.

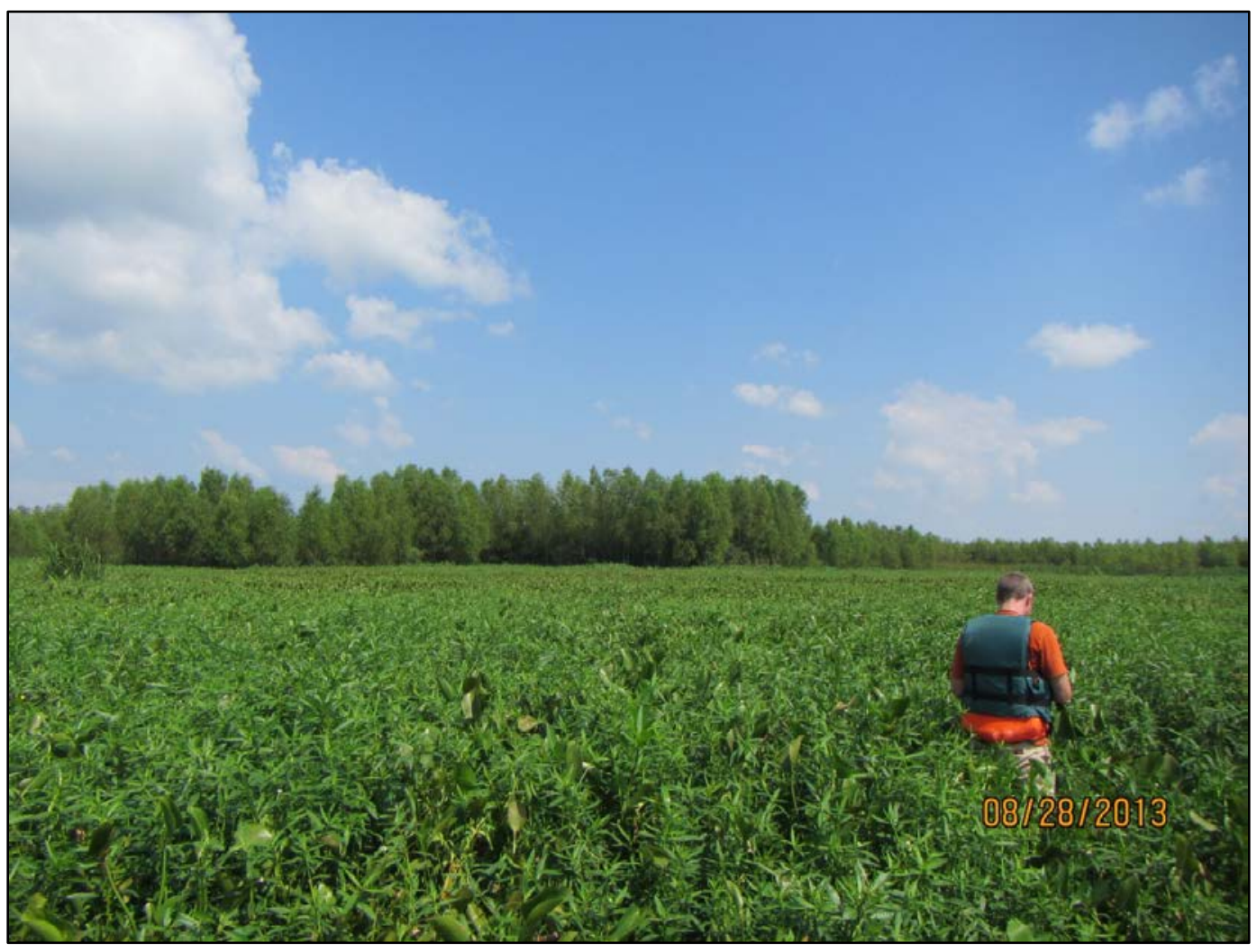

Table 5. Percent cover estimates for floating and submerged vegetation on Horseshoe Bend Island.

\begin{tabular}{|l|l|c|}
\hline \multicolumn{1}{|c|}{ Species } & \multicolumn{1}{c|}{ Common name } & Average cover (\%) \\
\hline Eichhornia crassipes & common water hyacinth & 37.5 \\
\hline Alternantherea philoxeroides & alligatorweed & 34.8 \\
\hline Salvinia minima & water spangles & 31.7 \\
\hline Lemna minor & common duckweed & 12.5 \\
\hline Ludwigia spp. & primrose-willow & 10.0 \\
\hline Hydrilla verticillata & waterthyme & 6.5 \\
\hline Nelumbo lutea & American lotus & 4.6 \\
\hline Leersia oryzoides & rice cutgrass & 1.0 \\
\hline Colocasia esculenta & coco-yam & 0.2 \\
\hline
\end{tabular}




\subsubsection{Island E}

Ten forested wetland and three scrub-shrub wetland sampling locations were sampled on Island E (Figure 13; Table 6). Tree stem density ranged from 100 to 1050 stems per hectare, with the average diameter at breast height ranging from of $12-30 \mathrm{~cm}$. Sapling density ranged from 200 to 18375 stems per hectare with a mean of 7000 stems per hectare. Average ground cover of herbaceous vegetation ranged from $50 \%$ to $99 \%$ with a mean coverage of $88 \%$.

The scrub-shrub areas were dominated by willows and wax-myrtle (Morella cerifera [L.] Small) with an increased abundance of buttonbush and alligatorweed. Otherwise, the forested and scrub-shrub areas displayed similar vegetation communities. Black willow disproportionately dominated sample plots, with wax-myrtle as a codominant in approximately half of the sample locations. Other woody species commonly observed included baldcypress (Taxodium distichum [L.] Rich.), annual marsh elder, and non-native Chinese tallowtree. In one sample location, red maple (Acer rubrum L.) saplings dominated with black willow interspersed; however, red maple was not frequently observed across the entire island. Honeylocust (Gleditsia aquatica L.) and water locust (Gleditsia aquatica Marsh.) were infrequently encountered. In the understory, buttonbush and coco-yam were frequently observed. Coco-yam represented the dominant herb in many areas of the island, particularly in open areas and along the islands perimeter. Vines were also common within sample locations, with morning-glory (Ipomea spp.), cowpea (Vigna unguiculata [L.] Walp.), and peppervine being most prevalent. Knotweed (Polygonum spp. L.), alligatorweed, lizardtail (Saururus cernuus L.), and whorled marsh pennywort (Hydrocotyle verticillata Thunb.) were the most commonly observed low-growing herbs. Appendix A provides a full list of species observed.

Within the aquatic bed environment surrounding Island $\mathrm{E}$, the dominant aquatic plants, with average percent cover greater than $25 \%$, were common water hyacinth, American lotus (Nelumbo lutea Willd.), and water spangles (Table 7). 
Figure 13. A sample location on Island E. A forested wetland area can be seen in the foreground with an emergent wetland area in the background of the image.

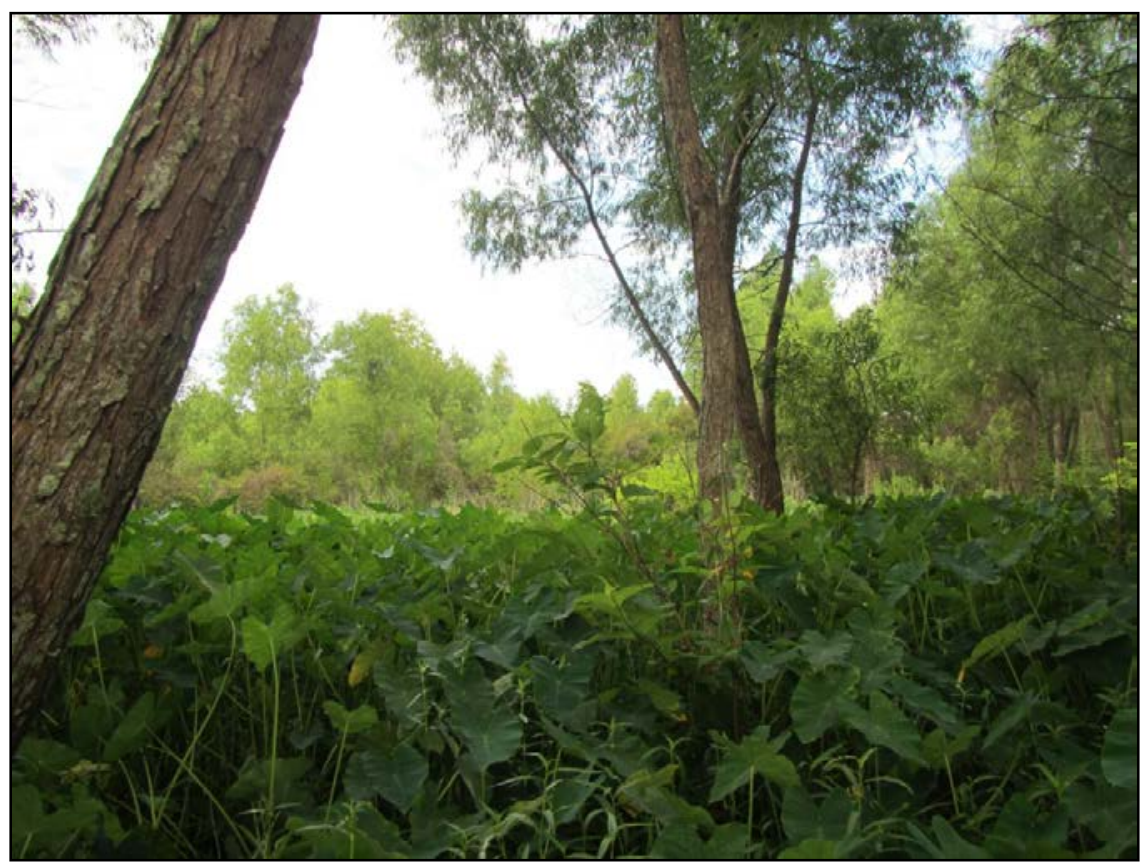

Table 6. Vegetation summary for forested and scrub-shrub wetlands on Island E. Data include the number of trees within each sample plot, dominant tree species, tree density, shrub-sapling density, ground vegetation within each sample plot, and average percent ground cover.

\begin{tabular}{|c|c|c|c|c|c|c|c|c|c|}
\hline \multirow[b]{3}{*}{ Site } & \multirow{3}{*}{$\begin{array}{l}\text { Tree } \\
\text { Stem } \\
\text { Count }\end{array}$} & \multirow{3}{*}{$\begin{array}{l}\text { Dominant } \\
\text { Species }\end{array}$} & \multirow{3}{*}{$\begin{array}{c}\text { Tree } \\
\text { Density } \\
\text { (stems/ha) }\end{array}$} & \multirow{3}{*}{$\begin{array}{l}\text { Sapling } \\
\text { Stem } \\
\text { Density } \\
\text { (stems/ha) }\end{array}$} & \multirow{2}{*}{\multicolumn{4}{|c|}{\begin{tabular}{|c|}
$\begin{array}{c}\text { Ground Vegetation Cover } \\
(\%)\end{array}$ \\
Plot \\
\end{tabular}}} & \multirow{3}{*}{$\begin{array}{c}\text { Ground } \\
\text { Cover } \\
\text { (\%) }\end{array}$} \\
\hline & & & & & & & & & \\
\hline & & & & & 1 & 2 & 3 & 4 & \\
\hline 1 & 287 & SANI* & 7175 & 125 & 35 & 20 & 30 & 40 & 31.3 \\
\hline 2 & 24 & SANI & 600 & 7750 & 15 & 85 & 80 & 30 & 53 \\
\hline 3 & 42 & SANI & 1050 & 3250 & 100 & 100 & 100 & 95 & 99 \\
\hline 4 & 16 & SANI & 400 & 3000 & 85 & 100 & 80 & 90 & 89 \\
\hline 5 & 17 & ACRU $^{\dagger} /$ SANI & 425 & 12375 & 90 & 95 & 80 & 90 & 89 \\
\hline $6 \ddagger$ & 4 & MOCE‡ & 100 & 18375 & 85 & 80 & 60 & 65 & 73 \\
\hline $7 \ddagger$ & 9 & SANI & 225 & 5250 & 95 & 90 & 95 & 95 & 94 \\
\hline 8 & 19 & SANI & 475 & 4500 & 100 & 90 & 95 & 80 & 91 \\
\hline 9 & 34 & SANI & 850 & 3375 & 90 & 100 & 90 & 85 & 91 \\
\hline 10 & 24 & SANI & 600 & 2125 & 100 & 95 & 90 & 80 & 91 \\
\hline 11 & 14 & MOCE & 350 & 14875 & 85 & 90 & 90 & 80 & 86 \\
\hline 12 & 21 & SANI & 525 & 2000 & 100 & 95 & 95 & 85 & 94 \\
\hline $13^{\ddagger}$ & 12 & SANI/MOCE & 300 & 8625 & 100 & 100 & 95 & 90 & 96 \\
\hline
\end{tabular}

* Salix nigra

${ }^{\dagger}$ Acer rubrum

₹ Morella cerifera 
Table 7. Percent cover estimates for floating and submerged vegetation on Island E.

\begin{tabular}{|l|l|c|}
\hline \multicolumn{1}{|c|}{ Species } & \multicolumn{1}{c|}{ Common name } & Average cover (\%) \\
\hline Eichhornia crassipes & common water hyacinth & 63.3 \\
\hline Nelumbo lutea & American lotus & 36.0 \\
\hline Salvinia minima & water spangles & 29.0 \\
\hline Lemna minor & common duckweed & 16.7 \\
\hline Ludwigia spp. & primrose-willow & 10.0 \\
\hline Leersia oryzoides & rice cutgrass & 10.0 \\
\hline Alternanthera philoxeroides & alligatorweed & 5.0 \\
\hline Amaranthus spp. & amaranth & 5.0 \\
\hline
\end{tabular}

\subsubsection{Middle Island}

Sampling occurred at 14 forested wetland locations on Middle Island (Figure 14; Table 8). Overstory dominant tree species were black willow, American sycamore (Platanus occidentalis L.), boxelder (Acer negundo L.), baldcypress, Chinese tallowtree, water oak (Quercus nigra L.), sugarberry (Celtis laevigata Willd.), and eastern cottonwood (Populus deltoides W. Bart. ex Marshall), respectively. Tree density ranged from 150 to 800 stems per hectare; average tree diameter ranged from 18 to $38 \mathrm{~cm}$. Sapling density ranged from 1000 to 6125 stems per hectare with a mean of 2500 stems per hectare. Stem density for dominant trees averaged 400 stems per hectare and sapling density averaging 2500 stems per hectare.

Shrub species, including wax myrtle, swamp privet (Forestiera acuminata [Michx.] Poir.), and possumhaw (Ilex decidua Walter), were observed although not dominant on the island. Dominant vines on Middle Island included American buckwheat vine (Brunnichia ovata [Walter] Shinners) and eastern poison ivy (Toxicodendron radicans [L.] Kuntze), with J apanese climbing fern (Lygodium japonicum [Thunb.] Sw.), trumpet creeper (Campsis radicans [L.] Seem. Ex Bureau), pepper vine, and climbing hempvine. Average ground cover was $60 \%$ with a range of $10 \%-100 \%$. No emergent aquatic vegetation was observed surrounding Middle Island. Appendix A provides a full list of species observed on Middle Island. 
Figure 14. Emergent wetland surrounded by a forested wetland area at a Middle Island sampling location.

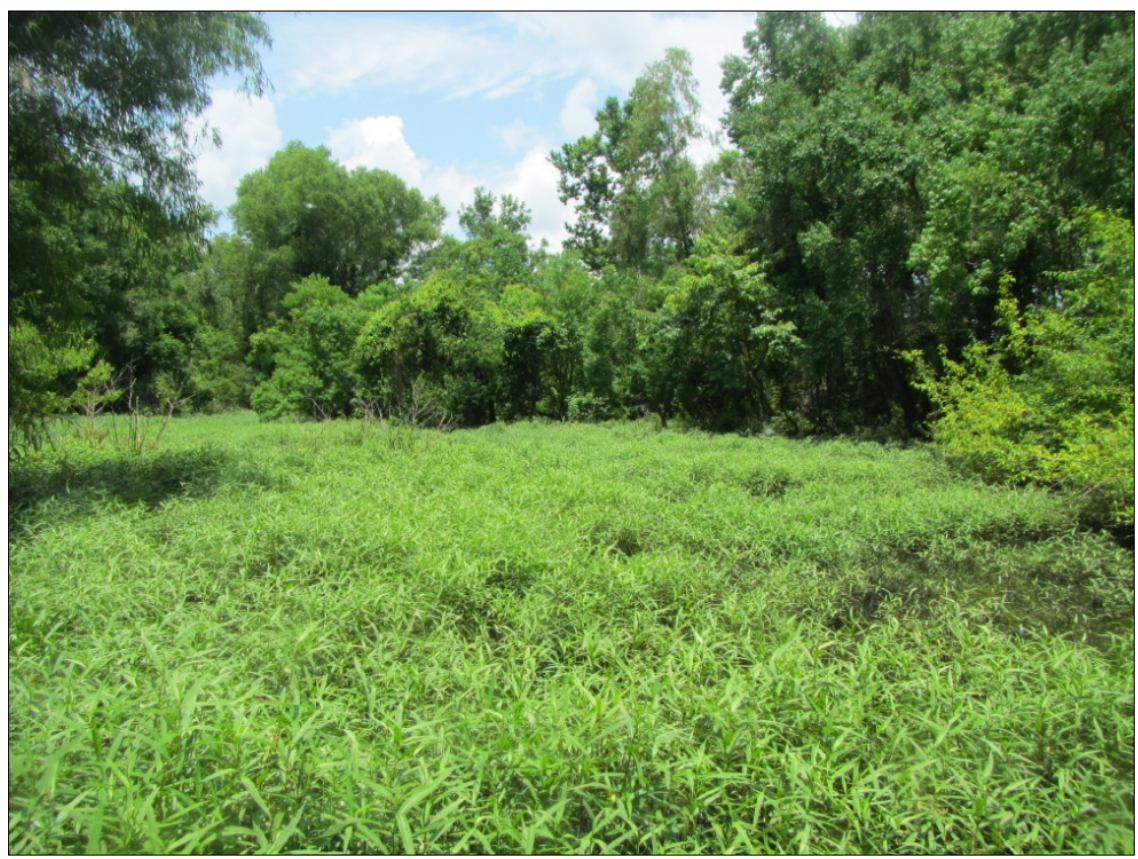

Table 8. Vegetation summary for wooded areas of Middle Island. Data include the number of trees within each sample plot, dominant tree species, shrub-sapling density, ground vegetation within each sample plot, and average percent ground cover.

\begin{tabular}{|c|c|c|c|c|c|c|c|c|c|}
\hline \multirow[b]{3}{*}{ Site } & \multirow{3}{*}{$\begin{array}{c}\text { Tree } \\
\text { Stems } \\
\text { (count) }\end{array}$} & \multirow{3}{*}{$\begin{array}{l}\text { Dominant } \\
\text { Species }\end{array}$} & \multirow{3}{*}{$\begin{array}{c}\text { Tree } \\
\text { Density } \\
\text { (stems/ha) }\end{array}$} & \multirow{3}{*}{$\begin{array}{l}\text { Sapling } \\
\text { Density } \\
\text { (stems/ha) }\end{array}$} & \multirow{2}{*}{\multicolumn{4}{|c|}{\begin{tabular}{|c|} 
Ground Vegetation Cover (\%) \\
Plot
\end{tabular}}} & \multirow{3}{*}{$\begin{array}{l}\text { Grounc } \\
\text { Cover } \\
(\%)\end{array}$} \\
\hline & & & & & & & & & \\
\hline & & & & & 1 & 2 & 3 & 4 & \\
\hline 1 & 12 & SANI/TADI & 300 & 1750 & 85 & 20 & 25 & 45 & 44 \\
\hline 2 & 11 & SANI/FRPE & 275 & 1875 & 40 & 25 & 60 & 70 & 49 \\
\hline 3 & 16 & SANI/PLOC & 400 & 2500 & 30 & 10 & 80 & 40 & 40 \\
\hline 4 & 10 & PLOC/SANI & 250 & 1500 & 100 & 100 & 100 & 100 & 100 \\
\hline 5 & 30 & SANI/TRCE & 750 & 1750 & 70 & 70 & 70 & 60 & 68 \\
\hline 6 & 19 & TADI/QUNI & 475 & 3625 & 30 & 40 & 40 & 10 & 30 \\
\hline 7 & 6 & PLOC/ACNI & 150 & 3125 & 40 & 100 & 90 & 100 & 83 \\
\hline 8 & 7 & ACNI/PLOC & 175 & 625 & 30 & 80 & 40 & 90 & 60 \\
\hline 9 & 10 & SANI/FRPE & 250 & 1000 & 100 & 100 & 100 & 100 & 100 \\
\hline 10 & 10 & PLOC/TRCE & 250 & 1125 & 100 & 70 & 100 & 50 & 80 \\
\hline 11 & 10 & SANI/PLOC & 250 & 2000 & 70 & 100 & 100 & 100 & 93 \\
\hline 12 & 17 & SANI/PLOC & 425 & 5500 & 30 & 90 & 100 & 100 & 80 \\
\hline 13 & 32 & PLOC/CELA & 800 & 2625 & 20 & 30 & 20 & 20 & 23 \\
\hline 14 & 27 & PLOC/PODE & 675 & 6125 & 5 & 10 & 5 & 20 & 10 \\
\hline$N I=$ & & & ULL & & & Era & enn & anica & \\
\hline $\begin{array}{l}\text { PLOC }= \\
\text { SANI }=\end{array}$ & $\begin{array}{l}\text { Platanus oc } \\
\text { alix niora }\end{array}$ & dentalis & $\begin{array}{l}\text { PODE }=\text { Populus } \\
\text { TADI }=\text { Taxodium }\end{array}$ & $\begin{array}{l}\text { deltoides } \\
\text { distichum }\end{array}$ & & Tria & $\begin{array}{l}\text { nigra } \\
\text { cebife }\end{array}$ & & \\
\hline
\end{tabular}




\subsection{Discussion}

The Horseshoe Bend Island displayed a diverse array of plant species supporting the larger Atchafalaya River wetland ecosystem, with 81 plant and 23 animal species observed (see Berkowitz et al. 2014). Lower speciesrichness values were observed at Island $\mathrm{E}$ and Middle Island. For contextual purposes, Faulkner and Poach (1996) assessed the functional capacity of created and natural wetlands within the Atchafalaya Delta and determined the functional capacity within each wetland type. Faulkner and Poach conducted a vegetation survey within created and natural wetlands, identifying a total of 53 plant species compared to more than 80 observed on Horseshoe Bend Island. Approximately $60 \%$ of the plant species reported by Faulkner and Poach listed occurred on Horseshoe Bend Island.

These findings suggest that the plant species richness and diversity observed at Horseshoe Bend Island remains comparable, if not surpasses, the values reported for other ecosystem studies conducted in the region. Additionally, Faulkner and Poach (1996) reported that created wetlands require 5 to 10 years prior to approaching the characteristics observed within natural wetland ecosystems. Thus, the successional development of Horseshoed Bend Island compares favorably with natural wetland ecosystems in coastal Louisiana based on the deposition periods of dredged materials and the resulting island geomorphic features and accretion rates. 


\section{Avian communities}

\subsection{Introduction}

The creation of dredged material islands has the potential to result in ecosystems that fulfill some of the ecosystem functions observed on natural islands (Faulkner and Poach 1996; University of New Orleans 2002). If engineered to mimic natural processes, over time, created dredge islands may begin to display ecosystem characteristics similar to natural islands although some studies suggest that long-term restoration outcomes remain unclear (Streever 2000; Shafer and Streever 2000). However, this dredged material island demonstration project is advancing the knowledge needed to support the efficacy of this novel dredging and dredged material placement technique.

Biological assessments using community composition metrics of a particular taxonomic group can be used to evaluate ecosystem condition in created habitats (USEPA 2002). Biological community characteristics can yield a great deal of information about a particular habitat because community composition can reflect the cumulative effect of multiple stressors. Additionally, repeated monitoring of community metrics can be used to track the success of created habitats over time. For created dredged material supported islands and other habitats, bird communities serve as useful indicators of habitat condition because they have complex communities that span a variety of ecological niches (Rabalais 1990). Additionally, many bird species have exhibited population declines and thus have been designated as species of concern (Partners in Flight 2006). Within the study area, Mallach and Leberg (1999) compared nesting densities and substrate characteristics within natural and dredged material supported islands. Many studies focus on wading-bird populations when assessing habitat quality because wading species selectively choose nesting colony locations based on specific habitat criteria (Piazza and Wright 2004; Frederick and Ogden 1997; Strong et al. 1997).

This section examines avian habitat on a non-traditionally engineered dredged material island and compares community metrics with those observed on a traditional dredge island (Island E) and a natural island (Middle Island). Through this comparison, the effectiveness of dredge island creation techniques for creating functional avian habitats can be evaluated as part of a multifactor assessment. 


\subsection{Methods}

Bird surveys occurred on 1- 2 J uly 2014. Transect surveys involved an observer traversing a straight line perpendicular to the long-axis orientation of the island and recording the number, species, and age class of all birds observed within $5 \mathrm{~m}$ of the transect center. Transects were located on the portion of the islands that contained forested and scrubshrub habitats that potentially provided nesting habitat for wading birds or foraging habitat for passerine species. The extent and location of forest habitat (Table 1) on each island also dictated the number, location, and total length of transects evaluated. Transects were located approximately $20 \mathrm{~m}$ apart to maintain independence among transects.

A total of eight transect surveys on Horseshoe Bend Island resulted in a total transect length surveyed of $760 \mathrm{~m}$. Bird surveys of Island $\mathrm{E}$ included two transects totalling $244 \mathrm{~m}$ surveyed. A single $324 \mathrm{~m}$ transect was surveyed on Middle Island. Bird community metrics included species richness and individual bird density, allowing for comparisons of avian habitat use between islands. Species-richness estimates represent the total number of bird species observed on transects at each sample location. Bird density was calculated as the total number of birds observed per meter of transect surveyed. Statistical analysis used Analysis of Variance (ANOVA) to compare bird richness and density between Horseshoe Bend Island and Island E; significance was evaluated at $\alpha=0.05$ (SPSS IBM, Inc. Version 20).

\subsection{Results}

\subsubsection{Horseshoe Bend Island}

Bird surveys of Horseshoe Bend Island yielded high numbers of breeding wading birds in dense, mixed-species nesting colonies (Figures 15-19). Total species richness was ten species (Table 9), including nine species of wading birds and one passerine species (Table 10). The most abundant species observed within the nesting colony was great egret (Ardea alba), followed by glossy ibis (Plegadis falcinellus). Of the 193 individuals recorded on surveys at Horseshoe Bend Island, 79\% were juveniles, suggesting that the island supports a highly productive nesting colony. 
Table 9. Comparison of bird community metrics across the three islands studied.

\begin{tabular}{|l|c|c|c|}
\hline \multicolumn{1}{|c|}{ Location } & Species Richness & (birds/m transect length) & \% Juveniles \\
\hline Horseshoe Bend Island & 10 & 0.27 & 78.76 \\
\hline Island E & 7 & 0.05 & 0 \\
\hline Middle Island & 13 & 0.09 & 0 \\
\hline
\end{tabular}

Table 10. Bird Species observed at Horseshoe Bend Island, Island E, and Middle Island.

\begin{tabular}{|c|c|c|c|c|}
\hline Species & Scientific Name & $\begin{array}{l}\text { Horseshoe } \\
\text { Bend Island }\end{array}$ & Island E & Middle Island \\
\hline Agelaius pheoniceus & \begin{tabular}{|l} 
red-winged \\
blackbird
\end{tabular} & $x$ & & \\
\hline Ajaia ajaja & roseate spoonbill & $x$ & & \\
\hline Archilochus colubris & $\begin{array}{l}\text { ruby-throated } \\
\text { hummingbird }\end{array}$ & $x$ & & $x$ \\
\hline Ardea alba & great egret & $x$ & & \\
\hline Baeolophus bicolor & tufted titmouse & $x$ & & \\
\hline Bubulcus ibis & cattle egret & $x$ & & \\
\hline Buteo lineatus & $\begin{array}{l}\text { red-shouldered } \\
\text { hawk }\end{array}$ & $\mathrm{x}$ & & \\
\hline Cardinalis & northern cardinal & $x$ & & \\
\hline Egretta caerulea & little blue heron & $x$ & $x$ & \\
\hline Egretta rufescens & reddish egret & $x$ & $x$ & \\
\hline Egretta thula & snowy egret & & $x$ & \\
\hline Egretta tricolor & tricolored heron & & $x$ & $x$ \\
\hline Eudocimus albus & white ibis & & $x$ & $x$ \\
\hline Melanerpes carolinus & $\begin{array}{l}\text { red-bellied } \\
\text { woodpecker }\end{array}$ & & $x$ & $x$ \\
\hline Porphyrula martinica & purple gallinule & & $x$ & \\
\hline Strix varia & barred owl & & & $x$ \\
\hline Polioptila caerulea & $\begin{array}{l}\text { blue-gray } \\
\text { gnatcatcher }\end{array}$ & & & $x$ \\
\hline Thryothorus ludovicianus & Carolina wren & & & $x$ \\
\hline Melanerpes carolinus & $\begin{array}{l}\text { red-bellied } \\
\text { woodpecker }\end{array}$ & & & $x$ \\
\hline Buteo lineatus & $\begin{array}{l}\text { red-shouldered } \\
\text { hawk }\end{array}$ & & & $x$ \\
\hline Archilochus colubris & $\begin{array}{l}\text { ruby-throated } \\
\text { hummingbird }\end{array}$ & & & $x$ \\
\hline Baeolophus bicolor & tufted titmouse & & & $x$ \\
\hline Vireo griseus & white-eyed vireo & & & $x$ \\
\hline Meleagris gallapavo & wild turkey & & & $x$ \\
\hline
\end{tabular}


Figure 15. Wading-bird nesting colony on Horseshoe Bend Island.

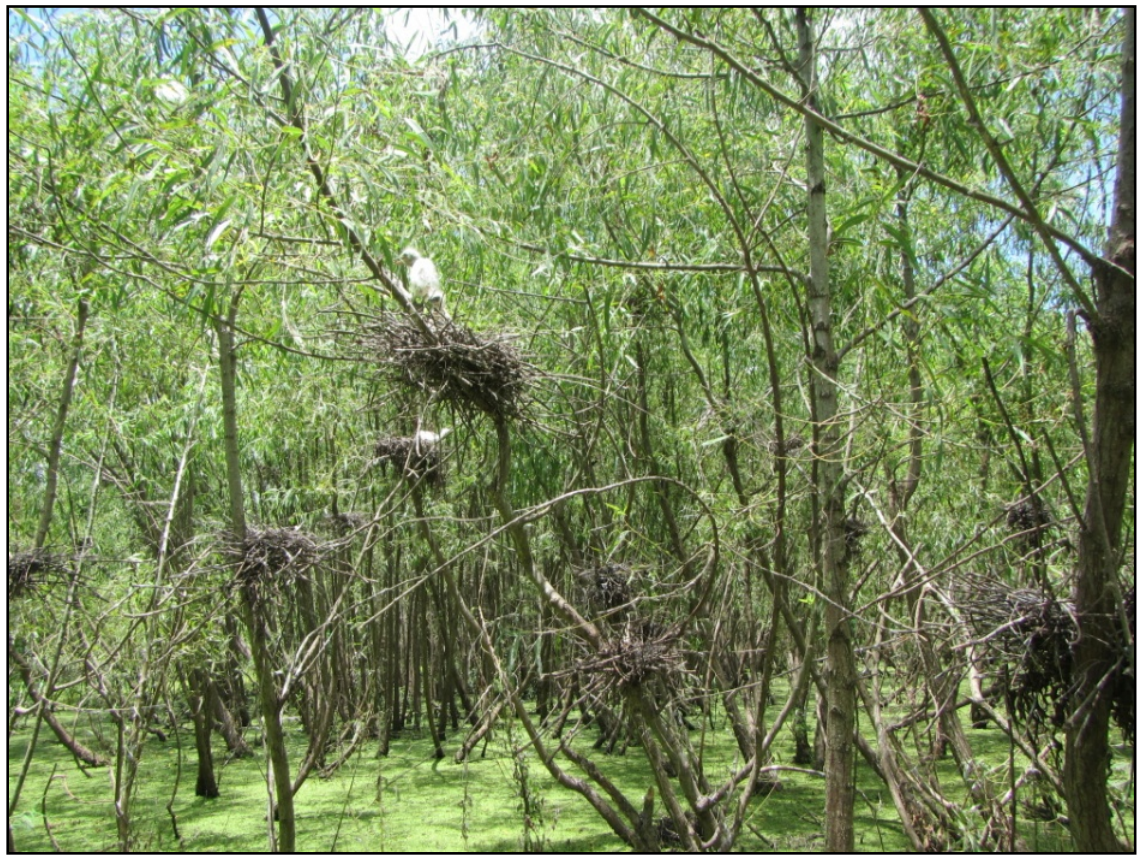

Figure 16. Juvenile tricolored heron observed during a transect survey on Horseshoe Bend Island.

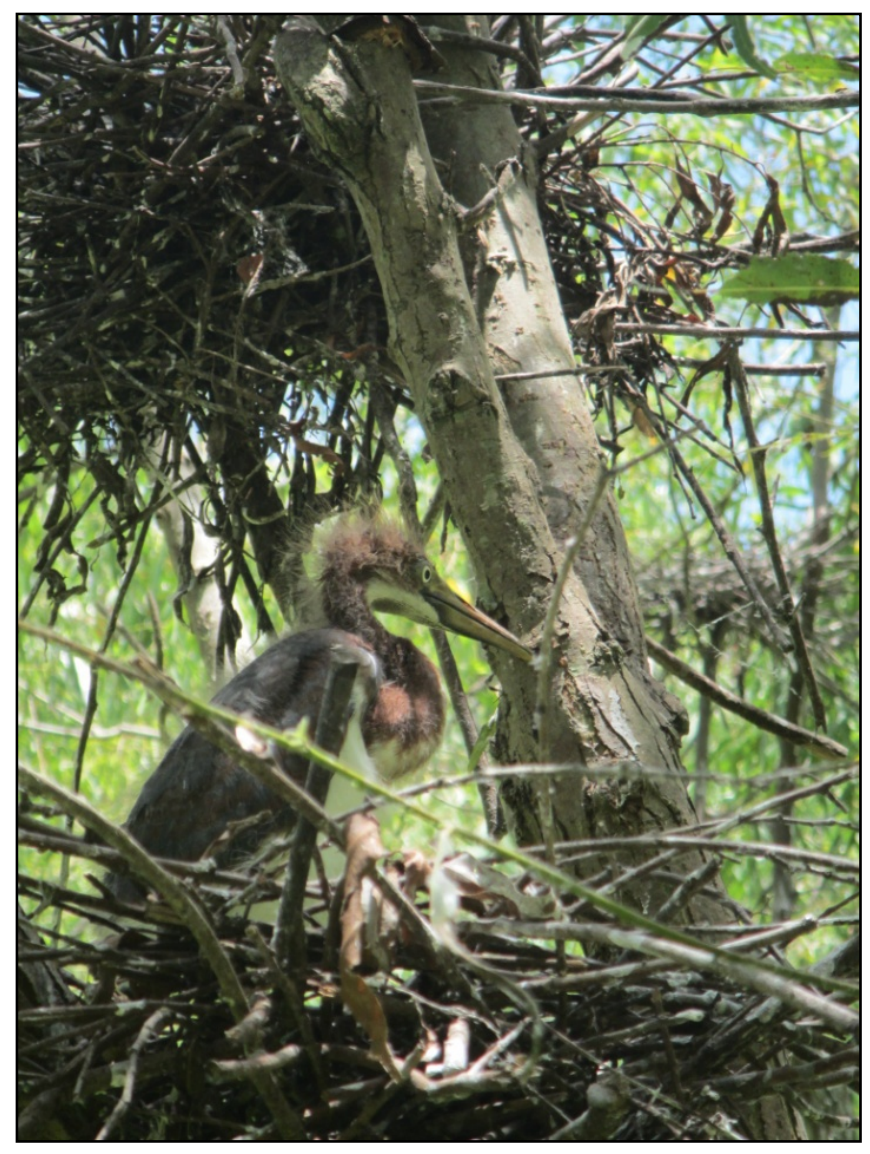


Figure 17. Juvenile snowy egret observed during a transect survey on Horseshoe Bend Island.

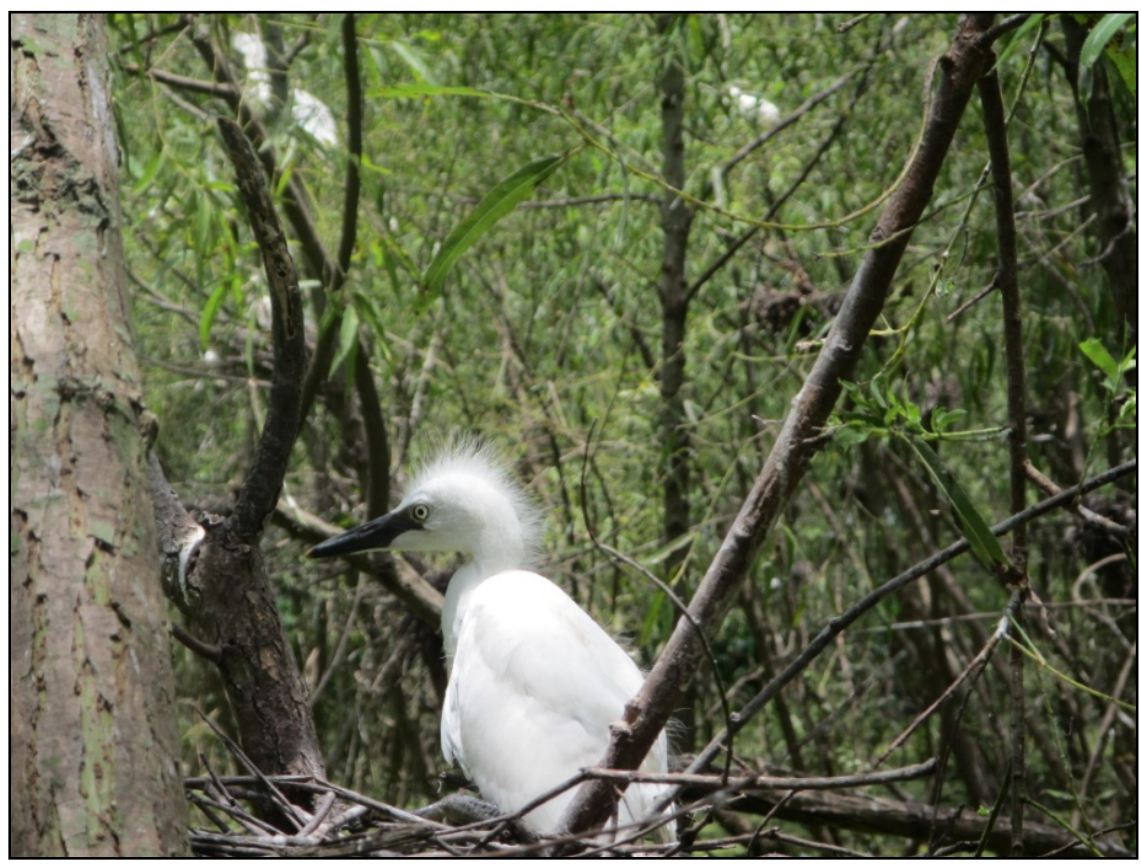

Figure 18. Juvenile glossy ibis observed during a transect survey on Horseshoe Bend Island.

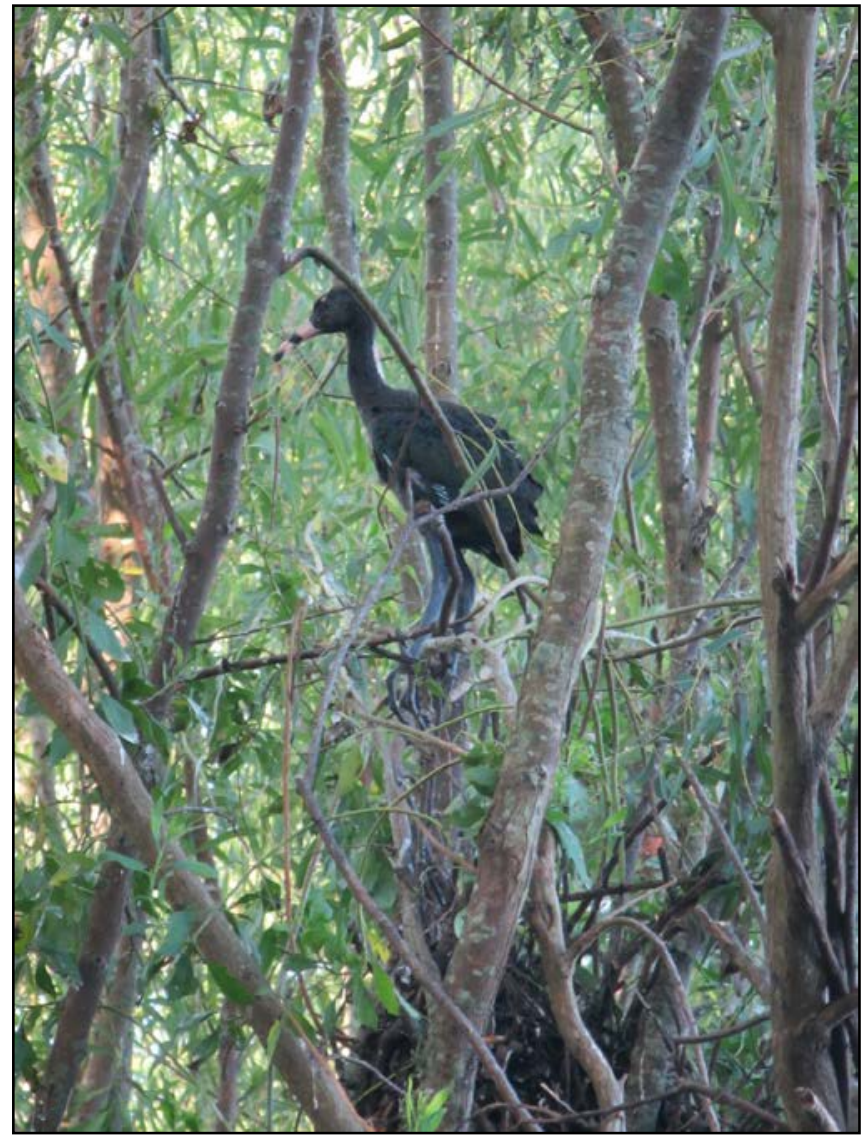


Figure 19. Forested wetland area within the wading-bird rookery on Horseshoe Bend Island. Note the presence of standing water below the nesting colony.

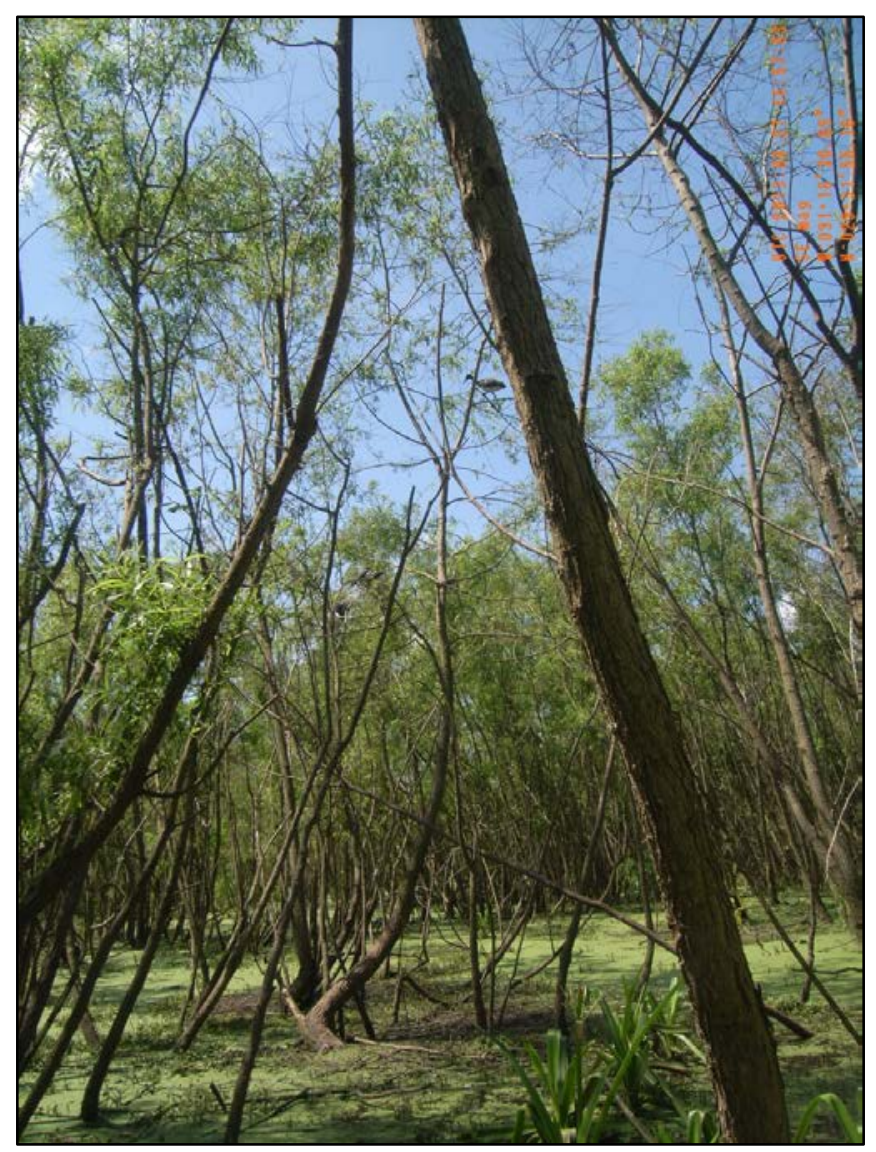

\subsubsection{Island E}

Total species richness on Island E was seven species (Table 9). Total bird density was low (0.05 birds/ $\mathrm{m}$ transect length). Only one individual wading bird was documented on Island E (Table 10), an adult white ibis (Eudocimus albus). Island E exhibited no sign of a wading-bird nesting colony.

\subsubsection{Middle Island}

A total richness of 13 species, the highest of the three islands surveyed, was documented at Middle Island (Table 9). The majority of birds documented were passerines (i.e., songbirds) (Table 10). A single great egret (Ardea alba) was the only wading bird documented, suggesting that Middle Island does not support a wading-bird nesting colony. Total bird density (0.09 birds/ $m$ transect length) was substantially lower than at Horseshoe Bend Island but somewhat higher than at Island E. 


\subsection{Discussion}

Results of statistical comparisons between Horseshoe Bend Island and Island $\mathrm{E}$ indicate that species richness of wading birds was significantly greater at Horseshoe Bend Island than at Island E $(F(1,6)=16.84, \mathrm{P}=$ $0.01)$. No juvenile birds were observed at Island $E$, resulting in a significantly higher estimate of percent juveniles at Horseshoe Bend Island ( $\mathrm{F}$ $(1,6)=85.42$, $\mathrm{P}<0.001)$. However, the two islands displayed similar species richness $(\mathrm{F}(1,6)=0.75, \mathrm{P}=0.42)$; and overall bird density was not significantly different between the two islands $(F(1,6)=1.06, P=0.34)$.

Based on the J uly 2014 bird survey data, Horseshoe Bend Island provides an important breeding habitat for wading birds, an ecosystem function not observed at the other two islands surveyed. Previous studies have also documented the use of dredged material islands by at least 26 species of colonial sea and wading birds (Schreiber and Schreiber 1978). The observed difference between bird community characteristics at the two dredged material supported islands suggests that Horseshoe Bend Island displays more favorable conditions for breeding wading birds, possibly as a result of the novel technique used for forming the island. Traditional dredge island construction at Island $E$ resulted in an area of emergent and scrubshrub wetlands near the center of the island, creating a lack of core forested habitat (Figure 5). In contrast, Horseshoe Bend Island contains proportionally more core forested habitat, which is related to nest site selection for herons (Gibbs and Kinkel 1997). McCrimmon (1978) found that within mixed-species nesting colonies, distance to forest edge influenced nest-site selection with some species more likely to be found closer to the edge than others.

Previous studies indicate that site selection for wading-bird nesting colonies is related to vegetation structure (Burger 1978; McCrimmon 1978). Of particular importance is the presence of rigid woody plants capable of offering nest stability (Beaver et al. 1980). Horseshoe Bend Island contains a high density of woody vegetation, providing structural support for heavy nests and nestlings. The vegetation density at Horseshoe Bend Island also results in high percent canopy closure (Table 4), which offers cover and mitigates temperature fluctuations in a region where average summer temperatures often exceed $90^{\circ} \mathrm{F}\left(32^{\circ} \mathrm{C}\right)$.

Hydrologic condition is another factor that may influence the availability of nesting and foraging habitat for wading birds (Strong et al. 1997). The 
two dredge islands examined show different hydrologic regimes, which may help to explain the difference in bird community characteristics between locations. Notably, the nesting colony area on Horseshoe Bend Island remains inundated with standing water during much of the nesting season (Figure 19). One can speculate that the presence of standing water beneath nesting trees during breeding season may facilitate nestling survival by discouraging predators, such as raccoons, rats, and snakes, a trend that has been documented for passerine species that nest in wetlands (Picman et al. 1993; Cain et al. 2003; Hoover 2006).

In addition to habitat characteristics that may influence the presence or absence of nesting wading birds, it should be noted that social stimulation is an important determinant in nest site selection, with the presence of other wading birds often being a key determinant in site selection (Beaver et al., 1980; Custer and Osborn 1978; Krebs 1974). For this reason, habitat use by colonial nesters can sometimes be unpredictable, and habitats with seemingly ideal conditions may not be selected.

Statistical comparisons regarding Middle Island, the naturally formed island, were not performed because only a single transect was conducted. A descriptive comparison between islands shows that Middle Island supported greater species richness than Horseshoe Bend Island. However, nesting wading birds were not observed on Middle Island, and overall bird density was comparatively higher at Horseshoe Bend Island as a result of its dense nesting colony. Despite the high numbers of wading birds documented on Horseshoe Bend Island, very few passerine species were observed. Tree size on Horseshoe Bend Island remained low in comparison with Middle Island, and many species of neotropical migrants using forested habitats prefer later successional forests. Should ongoing monitoring occur at Horseshoe Bend Island, it is possible that observations of passerine species would increase as forest structure continues to develop.

In summary, the strategic placement of dredged material at Horseshoe Bend Island resulted in the development of an exceptionally rich and productive colony of wading birds and thus represents a potential model for the future creation of dredge islands. Horseshoe Bend Island displayed higher wading-bird richness than a traditional dredged material island and a natural island in the region. The examination of avian communities contributes to a multifactor-assessment approach by examining vertebrate species near the top of the food chain. 


\section{Aquatic Invertebrates}

\subsection{Introduction}

Infaunal communities provide the basis of many aquatic food webs, supporting both demersal-feeding fish and a wide variety of wading bird species (Wells et al. 1973; Mathews et al. 1992). Examining infauna allows for comparisons between habitat types in early to mid-successional stages, as infauna have proven an effective measure of wetland restoration trajectory (Evans and Short 2005). Ewel et al. (2001) further points out that benthic infaunal communities quickly follow the establishment of restored wetlands, providing a responsive measure of a restoration success trajectory. For example, Ray (2000) examined infauna in natural and dredged material supported wetlands in the northeastern U.S., reporting similar species richness, abundance, composition, and diversity within 10 years of wetland creation. As a result, infaunal communities provide a valuable addition to a multifactor-assessment approach.

Many studies demonstrate that restored wetlands infaunal densities increased rapidly following restoration, including dredged material placement (Craft 2000). However, community metrics often fail to reach the levels observed in natural wetlands (Streever 2000; Craft et al. 2003). The following section examines sediment characteristics and infaunal community metrics at the three islands investigated. These results were used as an element of the multifactor approach assessing the strategic placement of dredged material for supporting wetlands.

\subsection{Methods}

Infaunal community sampling was conducted in two aquatic habitat types on Horseshoe Bend Island and Island E, including (1) along the wetland edge and (2) within emergent aquatic bed locations (Figure 20, left). Middle Island lacked emergent aquatic bed features, thus no aquatic bed samples were collected at that site. Invertebrate sampling occurred at three to five stations per sampling location, and each station included three replicate samples. All core samples were collected at water depths between 1 and $1.5 \mathrm{~m}$ (Figure 20, right). 
Figure 20. Left, the infaunal community sampling locations at Horseshoe Bend Island. Note that triplicate core samples were collected at the wetland edge and at five emergent aquatic bed (EAB) locations. Right, infaunal sampling used a $7.5 \mathrm{~cm}$ coring device.
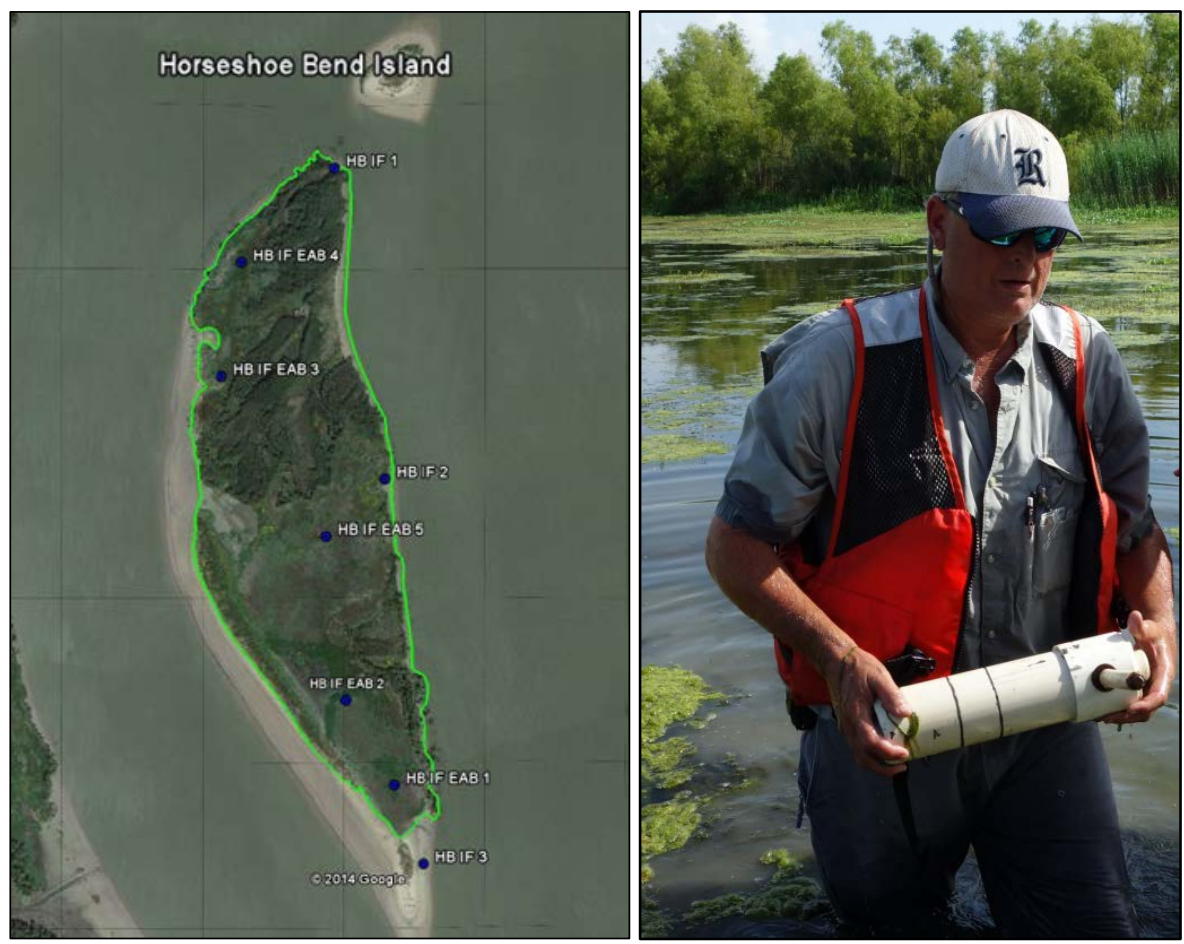

Infaunal sampling followed procedures outlined in Ray (2000) in which a $7.5 \mathrm{~cm}$ diameter coring tube was inserted to a sediment depth of $10 \mathrm{~cm}$. Samples were rinsed over a $0.5 \mathrm{~mm}$ mesh screen, fixed in $4 \%$ formalin, and transported to the laboratory where they were transferred to $70 \%$ ethanol and stained with rose bengal solution to facilitate sorting of specimens. After staining, the samples were examined under $3 \times$ magnification and the specimens separated from the remaining sediment and detritus and stored in $70 \%$ ethanol. When all infaunal samples had been processed, $10 \%$ of the samples were randomly selected and reexamined to ensure that all the invertebrate organisms were collected during initial processing efforts. Specimens were then identified to the lowest practicable taxonomic level and counted.

Particle size was determined using laser diffraction as described in Loizeau et al. (1994) and Konert and Vandenberghe (1997). Grain size analysis was conducted using the GRADISTAT software package following Blott and Pye (2001). Organic matter content determination followed the loss on ignition (LOI) method; dried ground samples underwent combustion at 
$550^{\circ} \mathrm{C}$ in a muffle furnace for $4 \mathrm{hr}$ (Sparks 1996). Community metrics calculated for comparison between sampling locations were taxonomic richness (i.e., total number of invertebrate taxa in each sample), abundance (total number of organisms), percent dominance (i.e., the percentage of each sample that is made up of the most abundant taxonomic group), and percent Chironomids (percentage of all organisms in each sample that were in the order Chironomidae). Comparisons of community metrics between islands combined data from both emergent aquatic bed and wetland edge sampling locations. Comparisons of sediment characteristics and community metrics included ANOVA when data were normally distributed; the non-parametric Mann-Whitney U and Kruskal-Wallace $\mathrm{H}$ tests were applied for comparisons involving non-normally distributed data. Normality testing used the Shapiro-Wilk test ( $\alpha=0.05$; SPSS statistics v.17.0).

\subsection{Results}

\subsubsection{Sediment characteristics}

Analysis of sediment particle size distribution demonstrates that all of the wetland sites examined were composed of a mixture of fine sands, silts, and clays with no very coarse sand or gravels present (Table 11). Silts re mained the most abundant size fraction at Island $\mathrm{E}$ emergent aquatic bed locations and at Middle Island while the sand fraction dominated all other sampling locations. Horseshoe Bend Island wetland edge samples contained significantly higher sand content $(89.8 \pm 2.7 \%$; $\mathrm{p}<0.001)$ than Island $\mathrm{E}(70.2 \pm 3.0 \%)$. Submerged aquatic bed habitats showed similar results with Horseshoe Bend Island $\mathrm{EAB}$ containing significantly higher sand content $(60.1 \pm 7.4 \% ; \mathrm{p}<0.001)$ than Island $\mathrm{E} \mathrm{EAB}(10.2 \pm 7.9 \%)$.

Table 11. Average sediment particle size distribution for Horseshoe Bend river wetland edge (HB) and emergent aquatic bed (HB EAB), Island E wetland edge (IE) and emergent aquatic bed (IE EAB), and Middle Island (MI) sample locations.

\begin{tabular}{|l|c|c|c|c|c|}
\hline Particles & HB & HB EAB & IE & IE EAB & MI \\
\hline$\%$ Sand & $89.8 \pm 2.7$ & $60.1 \pm 7.4$ & $70.2 \pm 3.0$ & $10.2 \pm 7.9$ & $39.8 \pm 6.2$ \\
\hline$\%$ Silt & $7.1 \pm 6.3$ & $34.4 \pm 6.7$ & $28.8 \pm 2.4$ & $73.0 \pm 4.7$ & $51.5 \pm 7.1$ \\
\hline$\%$ Clay & $3.1 \pm 1.9$ & $5.5 \pm 0.7$ & $1.0 \pm 0.6$ & $16.8 \pm 3.2$ & $8.69 \pm 4.2$ \\
\hline
\end{tabular}

Figure 21 presents the sediment organic matter content from each wetland. Craft (2000) and others report significant relationships between organic matter content and infaunal community metrics. Statistical analysis 
of organic matter content did not detect significant differences when comparing across wetlands (e.g., Horseshoe Bend Island vs. Island E). However, significant differences were detected between the wetland edge and emergent aquatic bed sampling locations (Mann-Whitney $U=26.5 ; p=$ 0.025) with emergent aquatic bed locations containing significantly higher organic matter concentrations than wetland edge locations.

Figure 21. Sediment organic matter content at Horseshoe Bend wetland edge (HB) and emergent aquatic bed (HB EAB), Island $E$ river shoreline (IE) and emergent aquatic bed (IE EAB), and Middle Island sample locations. Note that the emergent aquatic bed sediments $(*)$ contained significantly more organic matter than river shoreline locations.

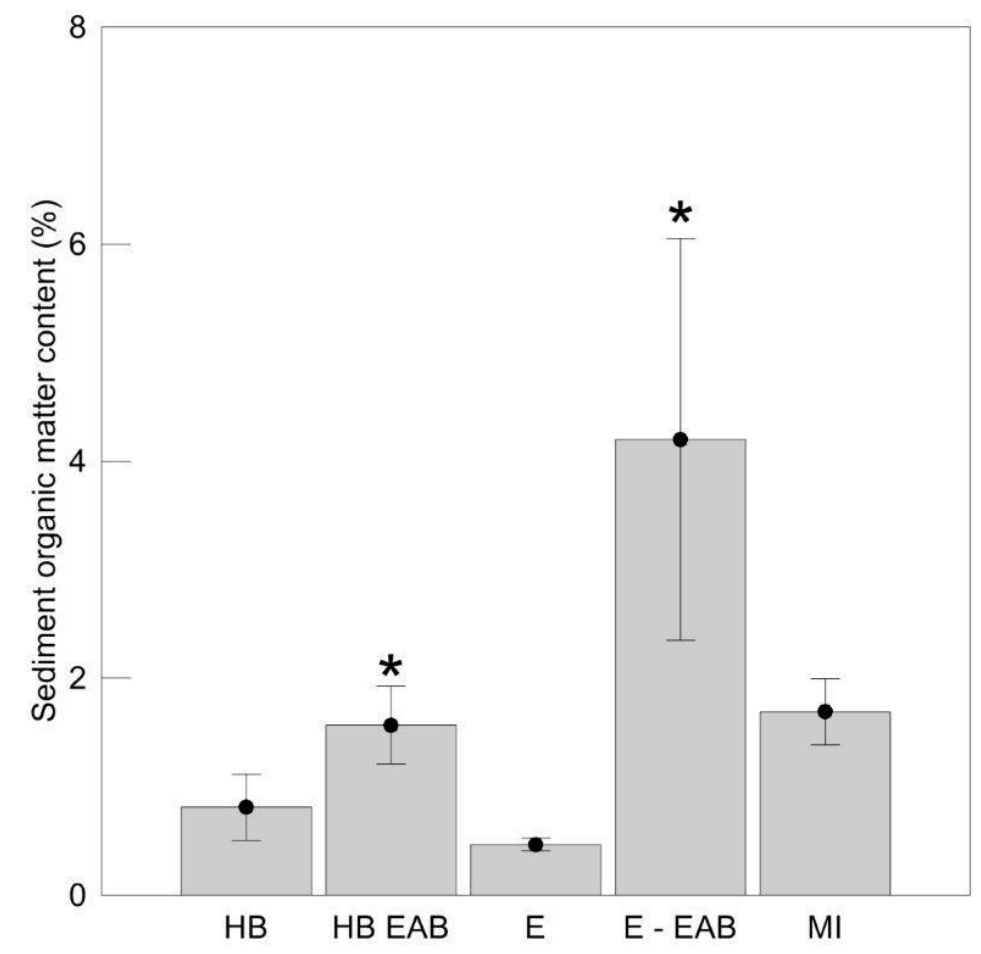

\subsubsection{Infaunal community metrics}

Taxonomic richness at both dredged material supported islands remained higher than at Middle Island. The highest richness values occurred in the Horseshoe Bend Island emergent aquatic bed sampling locations (average 13.8 species per sample), and the lowest richness values were observed in the Middle Island samples (1.3 species; Table 12). When samples from emergent aquatic bed and wetland edge locations were combined for each island, richness was significantly higher at Horseshoe Bend than at Middle Island ( $\mathrm{P}=0.01$; Table 13). Island $\mathrm{E}$ also displayed significantly higher richness than Middle Island $(\mathrm{P}=0.03)$. Species richness at Horseshoe Bend and Island $\mathrm{E}$ were not significantly different. 
Table 12. Average infauna community metrics at Horseshoe Bend Island (HB), Island $E(I E)$, and Middle Island (MI). Sampling locations included wetland edge (Edge) and emergent aquatic bed (EAB).

\begin{tabular}{|l|c|c|c|c|c|}
\hline Wetland & Sample location & Richness & \% Dominance & \% Chironomids & Abundance \\
\hline IE & Edge & 6 & 79.2 & 3.2 & 77 \\
\hline IE & EAB & 11.3 & 66.3 & 10.1 & 190 \\
\hline HB & Edge & 4.7 & 72.4 & 12 & 43 \\
\hline HB & EAB & 13.8 & 70.5 & 7.1 & 263 \\
\hline MI & Edge & 1.3 & 99.8 & 0.2 & 104 \\
\hline
\end{tabular}

Table 13. Statistical comparisons of infauna community metrics between sampling locations. Wetland site interaction included all three islands: Horseshoe Bend Island (HB), Island E (IE), and Middle Island (MI). Pair-wise comparisons were conducted between each wetland combination (e.g., HB vs. IE) and between the two sampling locations (Edge and EAB). Statistically significant results appear in bold $(\alpha=0.05)$.

\begin{tabular}{|l|l|l|c|c|c|c|c|}
\hline \multicolumn{1}{|c|}{ Data source } & Community Metric & Statistical Test & df & n & H/F & p \\
\hline Interaction between all wetland sites \\
\hline \multirow{4}{*}{ All } & Richness & Kruskal-Wallis & 2 & 17 & 7.44 & 0.02 \\
\cline { 2 - 7 } & $\%$ Dominance & Kruskal-Wallis & 2 & 17 & 7.02 & 0.03 \\
\cline { 2 - 7 } & $\%$ Chironomid & Kruskal-Wallis & 2 & 17 & 6.94 & 0.03 \\
\cline { 2 - 8 } & Abundance & Kruskal-Wallis & 2 & 17 & 0.11 & 0.95 \\
\hline
\end{tabular}

Pair-wise comparisons between wetland sites

\begin{tabular}{|c|c|c|c|c|c|c|}
\hline \multirow[t]{4}{*}{ HB vs. MI } & Richness & Kruskal-Wallis & 1 & 11 & 6.06 & 0.01 \\
\hline & \% Dominance & Kruskal-Wallis & 1 & 11 & 6.03 & 0.01 \\
\hline & $\%$ Chironomid & Kruskal-Wallis & 1 & 11 & 6.03 & 0.01 \\
\hline & Abundance & ANOVA & 1 & 11 & 0.64 & 0.44 \\
\hline \multirow[t]{4}{*}{ IE vs. MI } & Richness & Kruskal-Wallis & 1 & 9 & 4.94 & 0.03 \\
\hline & $\%$ Dominance & Kruskal-Wallis & 1 & 9 & 5.45 & 0.02 \\
\hline & \% Chironomid & Kruskal-Wallis & 1 & 9 & 3.38 & 0.07 \\
\hline & Abundance & Kruskal-Wallis & 1 & 9 & 0.07 & 0.8 \\
\hline \multirow[t]{4}{*}{ HB vs. IE } & Richness & ANOVA & 1 & 14 & 0.3 & 0.59 \\
\hline & $\%$ Dominance & Kruskal-Wallis & 1 & 14 & 0.02 & 0.9 \\
\hline & $\%$ Chironomid & ANOVA & 1 & 14 & 0.45 & 0.51 \\
\hline & Abundance & Kruskal-Wallis & 1 & 14 & 0.02 & 0.9 \\
\hline \multicolumn{7}{|c|}{ Pair-wise comparisons between sampling locations } \\
\hline \multirow[t]{4}{*}{ Edge vs. EAB } & Richness & ANOVA & 1 & 17 & 20.27 & $<0.001$ \\
\hline & \% Dominance & ANOVA & 1 & 17 & 3.15 & 0.1 \\
\hline & \% Chironomid & ANOVA & 1 & 17 & 0.99 & 0.33 \\
\hline & Abundance & Kruskal-Wallis & 1 & 17 & 5.8 & 0.02 \\
\hline
\end{tabular}


Compared to Middle Island, both created dredge islands showed lower percent dominance, a community metric that is associated with disturbance due to the disproportionately high occurrence of a single taxa. Percent dominance was comparable between the two dredge islands, Horseshoe Bend and Island E. Middle Island displayed significantly higher percent dominance than either Horseshoe Bend Island or Island $\mathrm{E}(\mathrm{P} \leq 0.02)$. Of the three samples collected at Middle Island, two contained only Oligochaete species and no other taxa, and the third sample contained $99.5 \%$ Oligochaetes. Horseshoe Bend and Island E showed a high percent dominance of Oligochaetes and Polychaetes (Annelid worms) but contained various other organisms. At Horseshoe Bend Island, six of the eight samples collected were dominated by Oligochaetes with the remaining two samples dominated by Polychaetes. Five of the six samples from Island $\mathrm{E}$ were dominated by Oligochaetes, and the remaining sample was dominated by Polychaetes.

Samples from Horseshoe Bend Island had the highest percent Chironomids, a taxa associated with tolerance to disturbance, while Middle Island contained very few Chironomids. Combined emergent aquatic bed and wetland edge samples at Horseshoe Bend Island showed significantly higher percent Chironomids than at Middle Island $(\mathrm{P}=0.02)$. At Island $\mathrm{E}$, percent Chironomids was not significantly different from either Horseshoe Bend Island or Middle Island.

Abundance was highest in the Horseshoe Bend Island emergent aquatic bed location and lowest in the Horseshoe Bend wetland edge location. There were no significant differences in abundance between dredged material supported islands. Samples from emergent aquatic bed locations showed significantly higher abundance than wetland edge samples, with two to six times the number of organisms observed in aquatic bed samples $(\mathrm{H}=0.02)$. Taxa richness also was significantly higher in aquatic bed locations than in wetland edge locations $(\mathrm{P}<0.001)$. Percent dominance and percent Chironomids were not significantly different between sampling locations.

\subsection{Discussion}

Sediment grain size distributions followed expected patterns observed in created riverine wetland locations. Faulkner and Poach (1996) examined created and naturally formed wetlands in the lower Atchafalaya River, re- 
porting that created wetlands exhibited coarser sediment grain size distributions in comparison to naturally formed wetlands. Our results conform to this trend. During the creation of Horseshoe Bend Island and Island E, river bedload sediments were dredged from within the river channel and deposited to an aerial height. As indicated above, Horseshoe Bend Island contained significantly higher sand contents than Island E ( $p<0.001)$.

The higher sand content at Horseshoe Bend Island can be attributed to construction technique, due to its mid-river location and the natural reworking of sediments following dredged material placement, allowing for the settlement of coarser particles while the fine soil materials were carried further downstream. Conversely, Island $\mathrm{E}$ was created using a technique in which sediment was deposited into a low velocity area along the river edge, promoting settling of fine sediment fractions during a single dredging event. The movement of fine materials downstream has potential implications for dredging economics and engineering. For example, if less material is deposited within a dredged material placement area, additional capacity is maintained for future maintenance dredging activities (USACE 1983). Emergent aquatic bed environments occur within the interior, protected portions of the dredged material supported islands, allowing for incoming suspended sediments to settle and accumulate. These emergent aquatic bed habitats contained significantly higher infaunal richness and abundance than other sampling locations.

Craft (2000) examined the density of Oligochaetes in created wetlands, reporting densities up to 3800 organisms $/ \mathrm{m}^{2}$. The current study sites yielded between 2777 and 19104 Oligochaetes $/ \mathrm{m}^{2}$. These values fall within the reported range of 380-99000 organisms $/ \mathrm{m}^{2}$ occurring in a natural wetland setting (Craft 2000). Both dredged material supported islands contained rich communities of infaunal organisms. However, the created islands, along with Middle Island, support a high percentage of disturbance-tolerant organisms, as observed in the percent dominance and percent Chironomid results. Data suggest that the two dredged material supported islands function similarly for providing infaunal habitat. The lack of a significant difference in abundance between dredged material supported islands suggests that differences in taxa richness are not due to a larger number of organisms being sampled on one island compared with another. Both islands displayed relatively high taxa richness and low percent dominance in comparison to the natural island sampled, indicating that the created islands are capable of supporting infaunal habitats comparable 
to the natural island examined. The inclusion of infaunal community metrics aids in the application of a multifactor-assessment approach. 


\section{Soils and Biogeochemical Activity}

\subsection{Introduction}

Soils play an important role in providing wetland functions, including nutrient cycling, carbon sequestration, and the removal of harmful elements and compounds (Smith and Klimas 2002). For example, Lindau and Hossner (1981) and Craft et al. (1999) demonstrated the ability of wetland soils to accumulate carbon following restoration and vegetation establishment. Mitsch et al. (2005) and Mitsch and Day (2006) discuss the ability of wetlands to remove excess nitrogen from surface waters, decreasing eutrophication and Gulf of Mexico hypoxic events. Those studies report nitrate-nitrogen removal capacities on the order of $46 \mathrm{~g}-\mathrm{N} \mathrm{m}^{-2} \mathrm{year}^{-1}$ in Louisiana wetlands. Faulkner and Poach (1996) investigated the phosphorus dynamics of natural and dredged material supported wetlands in the Atchafalaya River, indicating that natural phosphorous conditions will develop in created wetlands within 10-20 years of establishment.

Additionally, wetland soils provide the physical substrate required to support wetland habitat and hydrology functions (Vepraskas et al. 2001; Reddy and DeLaune 2008). For example, Berkowitz and White (2013) reported that more-developed soil profiles showed increased hydrologic function in restored Mississippi Valley wetlands. Craft (2000) demonstrated increases in invertebrate infaunal habitat associated with a restored soil chronosequence in North Carolina wetlands. Many studies link restored wetlands with avian and higher-organism functionality (Rabalais 1990; Mallach and Leberg 1999).

Although many studies examine the ability of wetlands to perform various ecosystem functions, few studies compare soil and biogeochemical parameters across dredged material placement techniques. The following section examines the soils within each of the three islands studied and compares soil parameters and activities between Horseshoe Bend Island and Island E, both formed by dredged material. This approach provides a platform for examining the impact of the dredged material placement technique on soil parameters and biogeochemical functions. 


\subsection{Methods}

\subsubsection{Soils}

Basic wetland soil descriptions were made at sample locations within forested and scrub-shrub wetland communities on each of three islands examined (USACE 2010; NRCS 2010). Soil descriptions included the determination of soil horizon, Munsell color, redoximorphic features, and field textural analysis. Soil descriptions focused on near-surface $50 \mathrm{~cm}$ horizons. Additionally, soil sample collections used $98 \mathrm{~cm}^{3}$ soil cores to determine volumetric water content and bulk density. Surface-soil horizon samples were analyzed for total moisture content $\left(105^{\circ} \mathrm{C}\right)$, total nitrogen, and total carbon concentration via combustion on an Elementar Vario Macro Carbon Nitrogen analyzer $\left(900^{\circ} \mathrm{C}\right)$ (Kahn 1998; Klute 1986).

\subsubsection{Soil Biogeochemistry}

Four soil cores were taken from representative areas within each habitat type during August 2014. Push cores were collected using $7 \mathrm{~cm}$ diameter acrylic tubes to collect approximately the top $30 \mathrm{~cm}$ of soil. The cores were placed in a core rack, covered, and stored at $4^{\circ} \mathrm{C}$. Homogenized soil subsamples from the top $0-5 \mathrm{~cm}$ of each core were used to investigate soil conditions within the zone of highest microbial activity (Gardner and White 2010). Analyses included particle size, soil organic matter content, bulk density, total carbon (TC), total nitrogen (TN), total phosphorus (TP), extractable ammonium ( $\left.\mathrm{NH}_{4}-\mathrm{N}\right)$, and soluble reactive phosphorus (SRP), and microbial biomass nitrogen (MBN).

Determining soil organic matter content followed the LOI method; dried ground samples underwent combustion at $550^{\circ} \mathrm{C}$ in a muffle furnace for 4 hours (Sparks 1996). Dry-weight bulk density was calculated from the total wet weight of the soil sample, corrected for moisture content, and divided by volume of the soil section. The TC and TN were measured on dried, ground soil samples by using an Elemental Combustion System (Costech Analytical Technologies, Inc., Valencia, CA). The TP was quantified using the ashing-digestion method as described by Andersen (1976). Extractable $\mathrm{NH}_{4}-\mathrm{N}$ and SRP were determined by a $2 \mathrm{M} \mathrm{KCl}$ (potassium chloride) extraction followed by filtering through a $0.45 \mu \mathrm{m}$ Supor- 450 membrane filter, acidified to a $\mathrm{pH}<2$, and stored at $4^{\circ} \mathrm{C}$ until analysis using a SEAL AQ2 Automated Discrete Analyzer (SEAL Analytical, West Sussex, England) (USEPA 1993). Detection limits for $\mathrm{NH}_{4}-\mathrm{N}$ and SRP were 
0.012 and $0.005 \mathrm{mg} \mathrm{L}^{-1}$, respectively. The MBN used the chloroform fumigation-extraction method (Vance et al. 1987) in which the total dissolved nitrogen (TDN), determined on a Shimadzu Scientific Instrument TOCVCSN (Columbia, MD), in non-fumigate samples is subtracted from TDN in fumigate samples.

Nutrient flux and potential nitrate reduction rates were determined using intact soil cores. The existing water column was siphoned out of each core and replaced with a $2 \mathrm{mg} \mathrm{L}^{-1}$ nitrate nitrogen $\left(\mathrm{NO}_{3}-\mathrm{N}\right)$ solution by using filtered Atchafalaya River water to create a water column of $15 \mathrm{~cm}(0.57 \mathrm{~L})$ (Theriot et al. 2013). Cores were incubated in a water bath maintained at $23.5^{\circ} \mathrm{C}$ under aphotic conditions. Each core was aerated using PharMed BPT tubing and Tetra ${ }^{\circledR}$ Whisper 40 UL Air Pumps to maintain uniform, aerobic conditions representative of the surface water in the river channel. Dissolved oxygen and $\mathrm{pH}$ were measured using a YSI 556 MPS (YSI Incorporated) on days 4 and 10 of incubation. Water samples were taken on initial reflooding and then every other day for a period of 10 days. During sampling, $6 \mathrm{ml}$ of water was removed from each water column and replaced with $6 \mathrm{ml}$ of deionized water. Each core was filled with deionized water to $15 \mathrm{~cm}$ prior to sampling to compensate for evaporative losses in the water column. Water samples were filtered through a $0.45 \mu \mathrm{m}$ syringe filter, acidified to $\mathrm{pH}<2$ for preservation, and stored at $4^{\circ} \mathrm{C}$ for $\mathrm{NO}_{3}-\mathrm{N}$, $\mathrm{NH}_{4}-\mathrm{N}$, and SRP colorometric determination as described above. Nitrate reduction rates were calculated by standardizing nitrate concentrations to core surface area over time.

The length of time each site was inundated was needed to estimate $\mathrm{NO}_{3}{ }^{-}$ removal in 2013 for both Horseshoe Bend Island and Island E. To do this, 2013 river stage data from the Lower Atchafalaya River at the Morgan City U.S. Geological Survey (USGS) monitoring station (USGS 07381600; www.USGS.gov) was paired with individual site elevation data to determine how many days in the year each island was submerged. Days inundated was averaged over each habitat type. The estimated days of inundation were then used in conjunction with average $\mathrm{NO}_{3}{ }^{-}$reduction rates and corresponding habitat area to determine approximate total $\mathrm{NO}_{3}-$ removed by each island during 2013. Nitrate-nitrogen removal estimates used the nitrate removal rates from core incubations combined with the habitat area and inundation period; this calculation assumed that denitrification occurred throughout periods of inundation. 
Statistical relationships were examined between habitat types (e.g., palustrine emergent vs. aquatic bed) and study areas (e.g., Island E vs. Horseshoe Bend Island) using ANOVA ( $\alpha=0.05$ ) with Tukey's post hoc analysis (SPSS v.17.0). Model assumptions were tested using Levene's test for equality of variance and the Shapiro-Wilk test for normality ( $\alpha=0.05)$. Data were transformed, as necessary, to meet model assumptions. Study area and habitat type were considered independent variables. Dependent variables included bulk density, soil organic matter, TC, TN, TP, extractable $\mathrm{NH}_{4}-\mathrm{N}, \mathrm{SRP}$, nitrateflux rates, $\mathrm{MBN}$, site elevation, and days inundated in 2013.

\subsection{Results}

\subsubsection{Soil descriptions}

The soils examined throughout the study area consisted of textures ranging from loamy sands to very fine sands. In general, surface soil layers contained thin, dark, organic-rich horizons (10YR 3/ 1 or 10YR 3/2) underlain by depleted materials (e.g., 10YR 5/2) in subsurface horizons. Soil horizons also exhibited redoximorphic iron and manganese concentrations in the form of rust-colored (e.g., 10YR 5/4) pore linings and masses within the soil matrix.

The presence of dark soil layers near the surface indicates the accumulation of carbon and organic materials due to frequent inundation and saturation and associated retardation of microbial decomposition rates. Additionally, the presence of depleted materials and redoximorphic features at depth indicates that biogeochemical reduction is occurring, an important function of hydric soils. All soils examined met one or more field indicators of hydric soils (NRCS 2010). Observed indicators included F3 (depleted matrix), S5 (sandy redox), and A5 (stratified layers). Many of the soils exhibited buried surface horizons, signatures of recent sediment inputs, and indicators of active soil-forming processes associated with overbank flooding and material deposition. Table 14 provides complete soil descriptions. 
Table 14. Soil descriptions indicating layer depth (cm), matrix color, redoximorphic features, and soil texture at each sample plot.

\begin{tabular}{|c|c|c|c|}
\hline Horseshoe Bend1 & Horseshoe Bend 2 & Horseshoe Bend 3 & Horseshoe Bend 4 \\
\hline $\begin{array}{l}\text { 0-30; } 10 \text { YYR } 5 / 2 \\
20 \% 7.5 \text { YR } 5 / 4 \\
\text { C/M/PL/LC }\end{array}$ & $\begin{array}{l}\text { 0-20; } 10 \text { YYR 5/2; } \\
\text { 20\% 7.5YR 5/4 } \\
\text { C/M/PL/LC }\end{array}$ & $\begin{array}{l}\text { 0-15; 10YR 5/3; } \\
\text { 10\% 10YR 5/6 } \\
\text { C/PL/LC }\end{array}$ & $\begin{array}{c}\text { 0-2; } 10 \text { Y } 3 / 1 ; \\
\text { high OC }\end{array}$ \\
\hline \multirow[t]{2}{*}{$\begin{array}{l}30-45 ; 10 Y R \text { 4/1; } \\
7 \% 7.5 Y R \text { 5/4 } \\
\text { C/M/PL/S }\end{array}$} & $\begin{array}{c}\text { 20-35; 10YR 4/1; } \\
\text { 2\% 7.5YR 5/4 } \\
\text { C/M/PL/LC }\end{array}$ & $\begin{array}{c}\text { 15-33; 10YR 5/1; } \\
\text { 20\% 7.5YR 5/6 } \\
\text { C/PL/LC }\end{array}$ & $\begin{array}{c}\text { 2-30 10YR 4/4; } \\
\text { 7\% 10YR 5/6 } \\
\text { C/M/LC }\end{array}$ \\
\hline & & $\begin{array}{c}\text { 33-43; 10YR 4/1; } \\
\text { 10\% 7.5YR 5/4 } \\
\text { C/M/S }\end{array}$ & $\begin{array}{c}\text { 30-40; 10YR 5/3; } \\
\text { 7\% 10YR4/6 CM; } \\
\text { 15\% 10YR 5/2 } \\
\text { D/M/LC }\end{array}$ \\
\hline Horseshoe Bend 5 & Horseshoe Bend 6 & Horseshoe Bend 7 & Island E 1 \\
\hline $\begin{array}{l}0-1 ; 10 Y R 5 / 2 \\
20 \% 10 Y R 5 / 6 \\
\text { C/M/PL/LC }\end{array}$ & $\begin{array}{c}\text { 0-1; } 10 \text { YR } 3 / 2 ; \\
\text { high OC }\end{array}$ & $\begin{array}{l}\text { 0-1; } 1 \text { OYR } 2 / 1 ; \\
\text { high OC }\end{array}$ & $\begin{array}{l}0-7 ; 10 Y R 5 / 2 ; \\
10 \% 7.5 Y R 5 / 6 \\
\text { C/PL/LC }\end{array}$ \\
\hline $\begin{array}{c}\text { 1-12; 10YR 4/2; } \\
5 \% \text { 10YR 5/6 } \\
\text { C/M/PL/Bw/LC }\end{array}$ & $\begin{array}{l}\text { 1-10; } 10 \text { YR 5/2; } \\
\text { 10\% 10YR 5/6 } \\
\text { C/PL/LC }\end{array}$ & $\begin{array}{c}\text { 1-15; 10YR 4/2; } \\
\text { 20\% 1OYR 5/4 } \\
\text { C/PL/M/LC }\end{array}$ & $\begin{array}{c}\text { 7-15; 10YR 5/2; } \\
\text { 35\% 7.5YR 5/6 } \\
\text { C/PL/LC }\end{array}$ \\
\hline \multirow[t]{2}{*}{$\begin{array}{c}\text { 12-43; 10YR 5/1; } \\
\text { 10\% 1OYR 4/6 } \\
\text { C/M/PL/LC }\end{array}$} & $\begin{array}{l}\text { 10-16; 10YR 3/1; } \\
25 \% 10 Y R 5 / 6 \\
\text { C/M/PL/Bw/LC }\end{array}$ & $\begin{array}{c}\text { 15-30; 10YR 5/1; } \\
\text { 5\% 10YR 5/6 } \\
\text { C/M/LC }\end{array}$ & $\begin{array}{c}\text { 15-25; } 10 \text { RR 4/1; } \\
\text { LC }\end{array}$ \\
\hline & $\begin{array}{c}16-40 ; 2.5 Y 5 / 1 \\
15 \% 10 Y R 4 / 6 \\
\text { C/PL/S }\end{array}$ & $\begin{array}{c}\text { 30-40; 10YR 5/3; } \\
\text { 10\% 10YR 5/6 } \\
\text { C/M/LC }\end{array}$ & 25-38; 10YR 5/1; S \\
\hline Island E 2 & Island E 3 & Middle Island 1 & Middle Island 2 \\
\hline $\begin{array}{c}\text { 0-7; } 10 \text { YR } 5 / 2 \\
\text { high OC }\end{array}$ & $\begin{array}{l}\text { 0-1; 10YR 2/1; } \\
\text { OC/Peat }\end{array}$ & 0-1; 10YR 2/1; L/C & 0-0.5; 10YR 2/1; LC \\
\hline 7-20; 10YR 4/1; LC & $\begin{array}{c}\text { 1-12; 10YR 4/2; } \\
\text { 30\% 10YR 5/6 } \\
\text { C/PL/LC }\end{array}$ & $\begin{array}{c}\text { 1-10; 10YR 4/2; } \\
\text { 10\% C 10YR 4/6 } \\
\text { PL/LC }\end{array}$ & $\begin{array}{c}\text { 0.5-15; 10YR 4/1; } \\
\text { 20\% 10YR 4/6 } \\
\text { C/PL/LC }\end{array}$ \\
\hline \multirow[t]{2}{*}{ 20-33; 10YR 4/1; S } & $\begin{array}{c}\text { 12-18; 10YR 4/1; } \\
\text { 2\% 10YR 4/4 } \\
\text { C/PL/LC }\end{array}$ & $\begin{array}{c}\text { 10-30; 10YR 5/1; } \\
\text { 15\% 10YR 4/4 } \\
\text { C/PL/LC }\end{array}$ & $\begin{array}{c}\text { 15-30 10YR 3/3; } \\
\text { 10\% 10YR 4/6 } \\
\text { C/PL/LC }\end{array}$ \\
\hline & 18-38; 10TR 4/2; S & & \\
\hline \multirow{2}{*}{\multicolumn{3}{|c|}{$\begin{array}{ll}\mathrm{C}=\text { redoximorphic concentration } & \mathrm{D}=\text { redoxir } \\
\mathrm{PL}=\text { pore lining } & \mathrm{S}=\text { sandy } \\
\mathrm{BW}=\text { buried soil horizon } & \mathrm{OC}=\text { high }\end{array}$}} & $\mathrm{M}=$ matrix \\
\hline & & & LC = loamy-clayey \\
\hline
\end{tabular}




\subsubsection{Soil nutrients and biogeochemical cycling}

As described above, soils on Horseshoe Bend Island displayed pedogenesis and the development of morphological features associated with developing wetland areas. Nutrient data demonstrates that Horseshoe Bend Island exhibits increasing soil TC and TN concentrations on the older, more mature portions of the island (Figure 22). These findings demonstrate that the island is accumulating soil nutrients as vegetative communities mature and carbon sequestration occurs. In the current study, soil C concentrations reached 1.8\% following 14 years of island development. Craft (2000) reported similar results with restored wetlands near coastal North Carolina, accumulating $2.0 \% \mathrm{C}$ within 15 years (converted from soil organic carbon as described in Pribyl [2010]). Nitrogen showed similar results with observed increases of $0.1 \%$ nitrogen occurring within 14 years of island establishment. Craft (2000) reported average concentrations of $0.1 \%$ over a 15-year-old restored wetland.

Figure 22. Soil carbon and nitrogen concentrations showed increases with stand age on Horseshoe Bend Island.
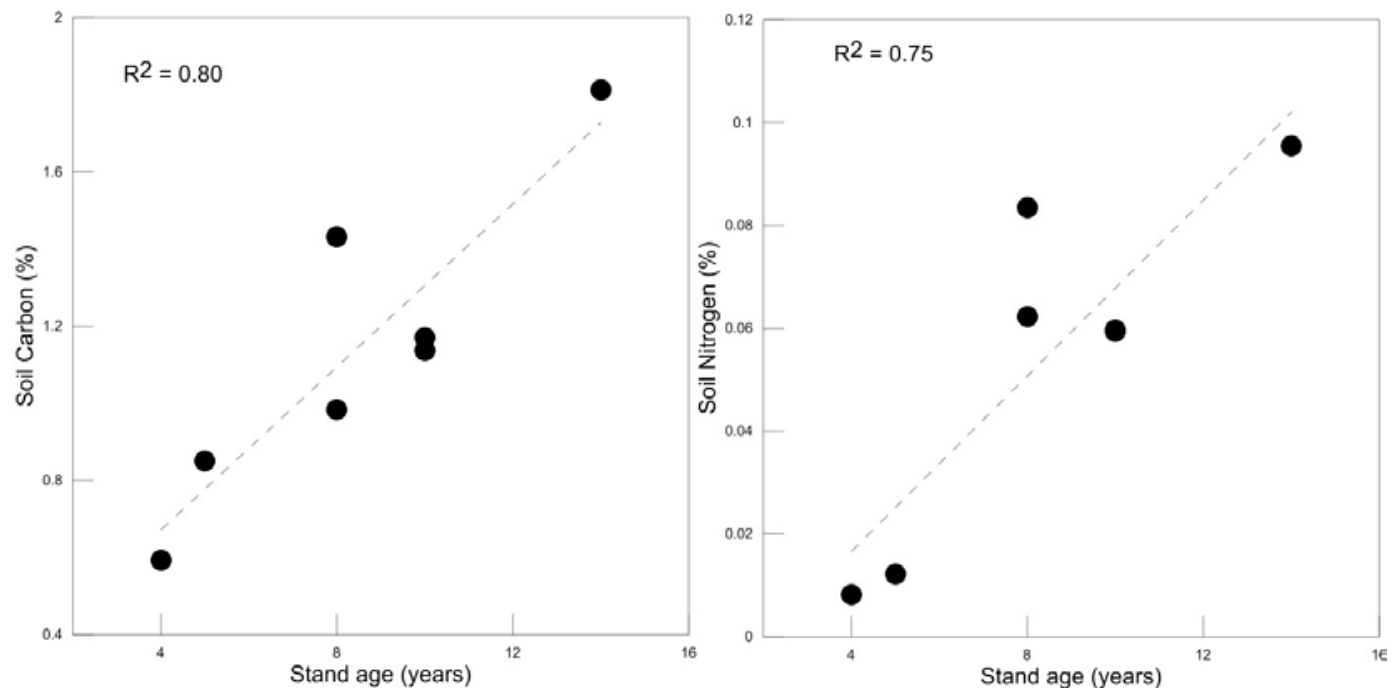

When comparing the two treatments, a number of soil parameters related to soil development and nutrient concentrations were significantly different between Horseshoe Bend Island and Island E (Table 15; Figure 23). The Horseshoe Bend Island was established in 1992, 8 years prior to the initial dredged material placement at Horseshoe Bend Island. As a result, portions of Horseshoe Bend Island were established 8- 18 years following the construction of Horseshoe Bend Island. The differences in wetland age coupled with the construction practices help to account for the observed differences in soil properties. For example, bulk density was significantly 
higher at Horseshoe Bend Island (mean $0.67 \mathrm{~g} \mathrm{~cm}^{-3}$ ) than at Island $\mathrm{E}$ (mean $0.35 \mathrm{~g} \mathrm{~cm}^{-3} ; \mathrm{p}=0.003$ ). Craft (2000) reported similar results with bulk density values of $0.7 \mathrm{~g} / \mathrm{cm}^{3}$ in 15 -year-old created wetlands, decreasing to $0.45 \mathrm{~g} / \mathrm{cm}^{3}$ after 25 years.

Table 15. Soil physical, nutrient, and biogeochemical properties and estimated nitrate removal calculation ( \pm standard error) at Horseshoe Bend Island (HB) and Island E (IE) habitats.

\begin{tabular}{|c|c|c|c|c|c|}
\hline \multirow[b]{2}{*}{ Parameter } & \multirow[b]{2}{*}{ Wetland } & \multirow[b]{2}{*}{ Aquatic } & \multicolumn{2}{|c|}{ Habitat type } & \multirow[b]{2}{*}{ Scrub-Shrub } \\
\hline & & & Emergent & Forested & \\
\hline \multirow{2}{*}{$\begin{array}{l}\text { Bulk Density } \\
\left(\mathrm{g} \mathrm{cm}^{-3}\right)\end{array}$} & $\mathrm{HB}$ & $0.6 \pm 0.15$ & $0.56 \pm 0.18$ & $0.65 \pm 0.05$ & $0.85 \pm 0.07$ \\
\hline & $\mathrm{IE}$ & $0.37 \pm 0.06$ & $0.27 \pm 0.03$ & $0.23 \pm 0.05$ & $0.52 \pm 0.08$ \\
\hline \multirow{2}{*}{$\begin{array}{l}\text { Organic Matter } \\
(\%)\end{array}$} & $\mathrm{HB}$ & $10.71 \pm 4.17$ & $10.08 \pm 2.88$ & $9.34 \pm 1.95$ & $3.95 \pm 0.63$ \\
\hline & $\mathrm{IE}$ & $10.23 \pm 1.14$ & $26.39 \pm 3.2$ & $35.6 \pm 7.55$ & $16.04 \pm 6.68$ \\
\hline \multirow{2}{*}{\begin{tabular}{|l}
$\mathrm{TC}$ \\
$\left(\mathrm{g} \mathrm{kg}^{-1}\right)$
\end{tabular}} & $\mathrm{HB}$ & $32.8 \pm 15.67$ & $34.16 \pm 10.8$ & $31.0 \pm 9.28$ & $12.66 \pm 2.06$ \\
\hline & $\mathrm{IE}$ & $23.18 \pm 0.62$ & $111.17 \pm 9.7$ & $153 \pm 31.4$ & $61.64 \pm 31.7$ \\
\hline \multirow{2}{*}{$\begin{array}{l}\text { TN } \\
\left(g_{k g}{ }^{-1}\right)\end{array}$} & $\mathrm{HB}$ & $3.09 \pm 1.58$ & $2.93 \pm 0.89$ & $2.5 \pm 0.72$ & $1.44 \pm 0.52$ \\
\hline & $\mathrm{IE}$ & $2.56 \pm 0.28$ & $8.55 \pm 0.53$ & $12.29 \pm 2.5$ & $4.51 \pm 2.1$ \\
\hline \multirow{2}{*}{$\begin{array}{l}\mathrm{TP} \\
\left(\mathrm{mg} \mathrm{kg}^{-1}\right)\end{array}$} & $\mathrm{HB}$ & $1007.8 \pm 409$ & $741.8 \pm 198$ & $585.33 \pm 89$ & $1650 \pm 1113$ \\
\hline & $\mathrm{IE}$ & $961.69 \pm 73$ & $707.8 \pm 154$ & $828.12 \pm 97$ & $463.02 \pm 106$ \\
\hline \multirow{2}{*}{$\begin{array}{l}\text { Extractable } \mathrm{NH}_{4}-\mathrm{N} \\
\left(\mathrm{mg} \mathrm{kg}^{-1}\right)\end{array}$} & $\mathrm{HB}$ & $56.41 \pm 28.29$ & $42.27 \pm 17.2$ & $26.09 \pm 7.2$ & $7.14 \pm 2.14$ \\
\hline & $\mathrm{IE}$ & $83.14 \pm 13.19$ & $48.49 \pm 18.2$ & $36.61 \pm 2.7$ & $13.39 \pm 8.12$ \\
\hline \multirow{2}{*}{$\begin{array}{l}\text { Extractable SRP } \\
\left(\mathrm{mg} \mathrm{kg}^{-1}\right)\end{array}$} & $\mathrm{HB}$ & 0 & 0 & $0.36 \pm 0.36$ & $1.56 \pm 0.98$ \\
\hline & $\mathrm{IE}$ & 0 & $0.04 \pm 0.04$ & $0.06 \pm 0.06$ & $0.01 \pm 0.01$ \\
\hline \multirow{2}{*}{$\begin{array}{l}\text { MBN } \\
\left(\mathrm{mg} \mathrm{kg}^{-1}\right)\end{array}$} & $\mathrm{HB}$ & $39.33 \pm 13.71$ & $19.93 \pm 3.7$ & $62.0 \pm 28.0$ & $29.33 \pm 11.24$ \\
\hline & $\mathrm{IE}$ & $18.25 \pm 6.93$ & $37.67 \pm 15.9$ & $51.2 \pm 19.1$ & $47.73 \pm 7.76$ \\
\hline \multirow{2}{*}{$\begin{array}{l}\mathrm{NO}_{3}-\mathrm{N} \text { flux } \\
\left(\mathrm{mg} \mathrm{m}^{-2} \text { day-1 }^{-1}\right)\end{array}$} & $\mathrm{HB}$ & $-19.3 \pm 4.2$ & $-35.7 \pm 3.4$ & $-22.5 \pm 6.7$ & $-23.4 \pm 4.4$ \\
\hline & $\mathrm{IE}$ & $-27.8 \pm 9.3$ & $-31.0 \pm 4.7$ & $-14.2 \pm 4.7$ & $-23.4 \pm 4.9$ \\
\hline
\end{tabular}

\begin{tabular}{|l|c|c|c|c|c|c|}
\hline Wetland & Habitat Type & $\begin{array}{c}\text { Area } \\
\left(\mathrm{m}^{2}\right)\end{array}$ & $\begin{array}{c}\text { Average } \\
\mathrm{NO}_{3}-\mathrm{N} \text { flux } \\
\left(\mathrm{mg} \mathrm{m}^{-2} \mathrm{~d}^{-1}\right)\end{array}$ & $\begin{array}{c}\text { Inundation } \\
\left(\mathrm{d} \mathrm{yr}^{-1}\right)\end{array}$ & $\begin{array}{c}\mathrm{NO}_{3}-\mathrm{N} \mathrm{removed}_{\left(\mathrm{kg} \mathrm{NO}_{3}-\mathrm{N} \mathrm{yr}^{-1}\right)} \\
(\mathrm{HB}\end{array}$ & $\begin{array}{c}\text { Total } \mathrm{NO}_{3}-\mathrm{N} \\
\text { removed } \\
\left(\mathrm{kg} \mathrm{NO}_{3}-\mathrm{N} \mathrm{yr}^{-1}\right)\end{array}$ \\
\cline { 2 - 7 } & Equatic & 191092 & $-19.3 \pm 4.2$ & $360.0 \pm 2.8$ & 1325.8 & 1645.5 \\
\cline { 2 - 7 } & Forested & 100160 & $-22.5 \pm 6.8$ & $69.8 \pm 8.6$ & 157.5 & \\
\cline { 2 - 7 } & Shrub/Scrub & 14488 & $-23.0 \pm 4.4$ & $63.8 \pm 4.2$ & 21.7 & \\
\hline IE & Aquatic & 134760 & $-27.7 \pm 9.3$ & $351.0 \pm 3.5$ & 1312.7 & 1577.2 \\
\cline { 2 - 7 } & Emergent & 19546 & $-31.0 \pm 4.7$ & $89.3 \pm 10.6$ & 54.1 & \\
\cline { 2 - 7 } & Forested & 68716 & $-41.2 \pm 5.4$ & $70.0 \pm 4.5$ & 198.2 & \\
\cline { 2 - 7 } & Shrub/Scrub & 8458 & $-32.4 \pm 5.0$ & $61.5 \pm 11.4$ & 12.2 & \\
\hline
\end{tabular}


Figure 23. Comparison of (a) soil carbon (C), (b) soil nitrogen (N), (c) soil organic matter, and (d) bulk density at Horseshoe Bend Island and Island E. Columns with different letters were statistically different; error bars represent standard error.
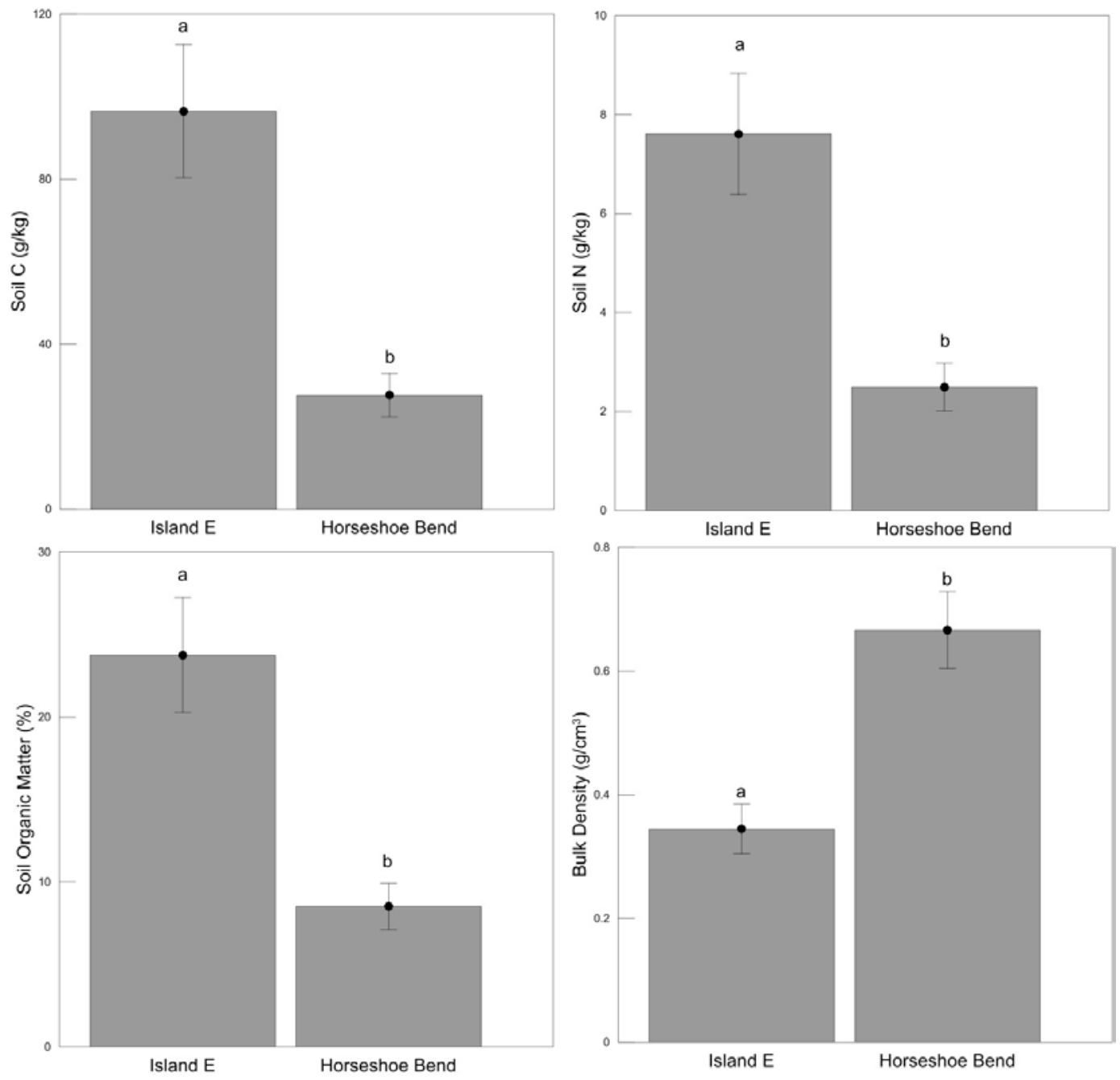

Soils at Horseshoe Bend Island contained significantly lower concentrations of soil nutrients than at Island $E$ with regards to soil organic matter $(p<0.001)$, TC $(p<0.001)$, and TN ( $p=0.001)$. No significant differences were identified in TP concentrations, extractable $\mathrm{NH}_{4}-\mathrm{N}$, or extractable SRP. The low extractable SRP at several sample locations (below detection) documents the phosphorous limitation of the system, similar to low phosphorous concentrations seen in the Mississippi River water (Roy et al. 2013).

The disparity in soil nutrient properties between the study sites cannot be easily attributed to either construction technique or site age (Craft et al. 1999). However, several general observations can be made to further discuss the implications of novel dredged material placement techniques. The 
Island $\mathrm{E}$ area is the product of dredged materials distributed via a hydraulic-pipeline delivery mechanism (Palermo and Francingues 1992; Palermo et al. 2009), which is very successful in building land though it leaves depressions, or "doughnuts," near the center of deposition where the pipeline aperture is positioned during sediment delivery. This technique leads to the deposition of fine materials. Conversely, the formation of Horseshoe Bend Island resulted from the reworking of dredged material placed upriver, resulting in creation of a linear feature oriented perpendicular to the direction of flow, similar to other mid-river wetlands in the region (Berkowitz et al. 2014). The relationship between soil texture and nutrient content is well documented (J enny 1980; Parton et al. 1987), with finer fractions associated with higher organic matter and nutrient content. Therefore, the lower nutrient values observed at Horseshoe Bend Island may be related to the coarse nature of sediments associated with the construction technique that mimics natural processes, in addition to difference in wetland age.

The microbial biomass represents a small but very active nutrient pool in the soil environment and, as a result, regulates the amounts of bioavailable nutrients in the system. Therefore, MBN serves as a proxy measure of microbial pool size in soils that can be linked to biogeochemical cycling (White and Reddy 2001). MBN averaged $37.6 \pm 14.1 \mathrm{mg} \mathrm{kg}^{-1}$ at Horseshoe Bend Island and $38.7 \pm 12.4 \mathrm{mg} \mathrm{kg}^{-1}$ at Island E. No significant differences in microbial pool sizes were detected between wetlands. The observed values compare well with the range of $20-35 \mathrm{mg} \mathrm{kg}^{-1}$ reported by VanZomeren et al. (2013) and agree with Groffman et al. (1996) who report microbial nutrient pools on the order of $1 \%-3 \%$ of the total nutrient concentrations. Conversely, these findings remain significantly lower than values reported by Gardner and White (2010) who reported MBN concentrations of $340 \mathrm{mg} \mathrm{N} \mathrm{kg}^{-1}$ in a wetland receiving flood waters from the Mississippi River. Notably, the soils examined by Gardner and White (2010) occurred within a well-established wetland exhibiting thick organic soils with more than $75 \%$ higher soil TN concentrations and significantly lower bulk density than those from the current study, accounting for the observed differences.

Extractable $\mathrm{NH}_{4}-\mathrm{N}$ represents the readily bioavailable nitrogen pool in the soil system, which can drive ecosystem primary productivity; Island E exhibited significantly more extractable $\mathrm{NH}_{4}-\mathrm{N}\left(40.0 \pm 7.6 \mathrm{mg} \mathrm{kg}^{-1}\right)$ than 
Horseshoe Bend Island ( $\left.25.8 \pm 5.5 \mathrm{mg} \mathrm{kg}^{-1} ; \mathrm{p}=0.025\right)$. This result suggests that there is ample bioavailable nitrogen in the soil to support the wetland vegetation.

Average $\mathrm{NO}_{3}-\mathrm{N}$ flux at Horseshoe Bend Island was $-25.2 \pm 2.94 \mathrm{mg} \mathrm{NO}_{3}-$ $\mathrm{N} \mathrm{m}^{-2} \mathrm{~d}^{-1}$ while at Island $\mathrm{E}$ the average $\mathrm{NO}_{3}-\mathrm{N}$ flux rate was $-30.8 \pm$ $2.19 \mathrm{mg} \mathrm{NO}-\mathrm{N} \mathrm{m}^{-2} \mathrm{~d}^{-1}$. There were no significant differences detected in $\mathrm{NO}_{3}-\mathrm{N}$ flux rates among wetlands or habitats, which suggest both wetlands have sufficient carbon availability and reducing conditions to process nitrate. These rates are comparable with the low ranges of nitrate reduction rates determined from Lake Pontchartrain sandy sediments at $-24.3 \mathrm{mg}$ $\mathrm{NO}_{3}-\mathrm{N} \mathrm{m}^{-2} \mathrm{~d}^{-1}$ (Roy and White 2012) and lower than maximum rates of $-40.3 \mathrm{mg} \mathrm{NO}_{3}-\mathrm{N} \mathrm{m}^{-2} \mathrm{~d}^{-1}$ found in an highly organic, freshwater wetland soil (Yu et al. 2006).

The only difference in potential removal of nitrate between sites is linked to the difference in elevation of each habitat type, with the lowest elevation flooded for a longer portion of the year with greater potential for removal of nitrate annually. To investigate this, potential $\mathrm{NO}_{3}-\mathrm{N}$ removal during 2013 was calculated for each wetland as a function of NO3-N flux, days inundated in 2013, and total wetland area (Table 15). The Horseshoe Bend Island wetland removed an estimated $1645 \mathrm{~kg} \mathrm{NO}-\mathrm{N}$ while Island $\mathrm{E}$ removed an estimated $1577 \mathrm{~kg} \mathrm{NO}_{3}-\mathrm{Ny}^{-1}$ for 2013. There was no significant difference between potential nitrate reduction capacity for the two wetlands. Aquatic bed habitats displayed significantly higher potential $\mathrm{NO}_{3}-\mathrm{N}$ removal rates than other wetland types $(p<0.001)$ because of their lower elevations. Submerged aquatic bed habitats are inundated year-round, promoting anaerobic conditions; contain significantly higher organic matter contents that other habitats ( $p=0.034)$; and have continuous inputs of nitrogen in river water, providing a hot spot for nutrient reduction via denitrification, assimilation, and other mechanisms.

\subsection{Discussion}

The soils observed within the created wetland islands display common characteristics associated with riverine wetlands exposed to periodic inundation, overbank flooding, and sediment deposition. Soil profiles indicate an abundance of depleted materials interspersed with higher chroma sandy minerals from recent flooding events. Notably, buried soil horizons and wavy boundary transitions demonstrate the frequency of deposition events as observed through the presence of stratified layers (NRCS 2010). 
Further, the development of dark, organic rich surface horizons indicates a decrease in microbial decomposition rates due to periodic saturation or inundation. The profusion of redoximorphic features within subsurface layers demonstrates that soil biogeochemical reduction regularly occurs within island soils. The onset of reduced, anaerobic conditions promotes wetland biogeochemical functions, including carbon sequestration, nutrient cycling, removal and sequestration of elements and compounds, and denitrification (Reddy and DeLaune 2008; Smith and Klimas 2002).

As expected, the soil characteristics of Horseshoe Bend Island continue to develop, with older portions of the island displaying increased nutrient concentrations. Additionally, Horseshoe Bend Island contains less soil carbon, nitrogen, and organic matter and higher bulk density (i.e., the soils are less developed) than Island E, which was established 7 year prior. Rates of soil microbial activity at the dredged material supported islands proved comparable to results reported in the literature for other natural and constructed wetlands in southern Louisiana. Also, the dredged material supported islands demonstrated the capacity to remove nutrients from overlying floodwaters and to contribute to water quality improvements associated with decreasing the hypoxic zone in the Gulf of Mexico.

The calculations presented above are theoretical, assuming anaerobic conditions during periods of inundation, a constant $\mathrm{NO}_{3}-\mathrm{N}$ concentration in the river water, and no fluctuations in $\mathrm{NO}_{3}-\mathrm{N}$ removal rates over time. The potential $\mathrm{NO}_{3}-\mathrm{N}$ removal in the study area represents only a minute fraction of the 20 million tons of nitrate entering the Mississippi River system per year (Goolsby et al. 1999), contributing less than $0.001 \%$ of the estimated 21,000-52,000 km² of created or restored wetlands required to significantly decrease $\mathrm{NO}_{3}-\mathrm{N}$ loading to the Gulf of Mexico (Mitsch et al. 2001). However, the results of the current study demonstrate that despite the differences in soil physical parameters and nutrient concentrations, the wetlands examined display equivalent levels of biogeochemical function and nutrient removal capacity.

An additional potential benefit of the Horseshoe Bend Island site is that the river water can access the marsh from all edges due to its location fully within the main river channel while the Island E sites have limited exchange with the river water on one side as they are located along the edge of the channel. Consequently, a wetland created using EWN techniques may be able to process more nitrate than an equally sized traditional 
dredged material constructed wetland (e.g., Island E). Future work should seek to quantify the difference in hydrologic connectivity with the river. Results of this study suggest that the novel engineering and construction techniques associated with EWN are a viable option for creating wetlands capable of nitrate reduction. Additionally, future projects using EWN principles should focus on maximizing creation of submerged aquatic bed habitat to take advantage of the great nutrient reduction potential of this habitat type. 


\section{Hydrodynamics and Sediment Transport Modeling}

\subsection{Introduction}

The strategic placement of dredged materials has been shown to provide habitat, storm surge reduction, improved navigation, and other benefits (Yozzo et al. 2004; Day et al. 2007). However, few studies have examined the impact of open-water dredged material placement, especially in a riverine setting. To address this data gap, the following section describes results from two modeling efforts examining the hydrodynamics and sediment transport characteristics occurring at Horseshoe Bend Island.

The Lower Atchafalaya River is connected to Gulf Intracoastal Water Way (GIWW), Bayou Boeuf, Bayou Penchant, Avoca Island Cutoff, and Shell Pass (Figure 24), thus representing an important navigable waterway linking the Gulf of Mexico and inland communities and waterways. The range of hydrological cycles and tidal conditions of Atchafalaya Bay provides a typical river-lake-estuary-bay system hydrodynamics response (Wang 1984). The system is thus controlled by hydrology, meteorology, and astronomical tides with varying time scales. Upstream, river hydrodynamics near Morgan City remain dominated by hydrological influence and tidal flows that modulate the strong river inflows, especially during the spring and summer wet season. Downstream areas are dominated by micro-tidal circulation patterns influenced by weather patterns.

Previous studies suggest that relocation of the Federal navigation channel to the east of Horseshoe Bend Island would reduce maintenance dredging efforts. Thus, two modeling studies-through a one-dimensional model, Hydrologic Engineering Center (HEC)-6T, and a two-dimensional model, Resource Management Associates (RMA)-2, were applied to the lower Atchafalaya River. Study results provide insight into the impact of strategic dredged material placement and the formation of Horseshoe bend Island on current hydrodynamics and sediment processes within the river. Additionally, modeling approaches allow for predictions regarding the future trajectory of Horseshoe Bend Island development and the impact of hydrodynamics and sediment transport on navigation. 
Figure 24. Horseshoe Bend Island and the lower Atchafalaya River basin in coastal Louisiana. North is at the top of the figure.

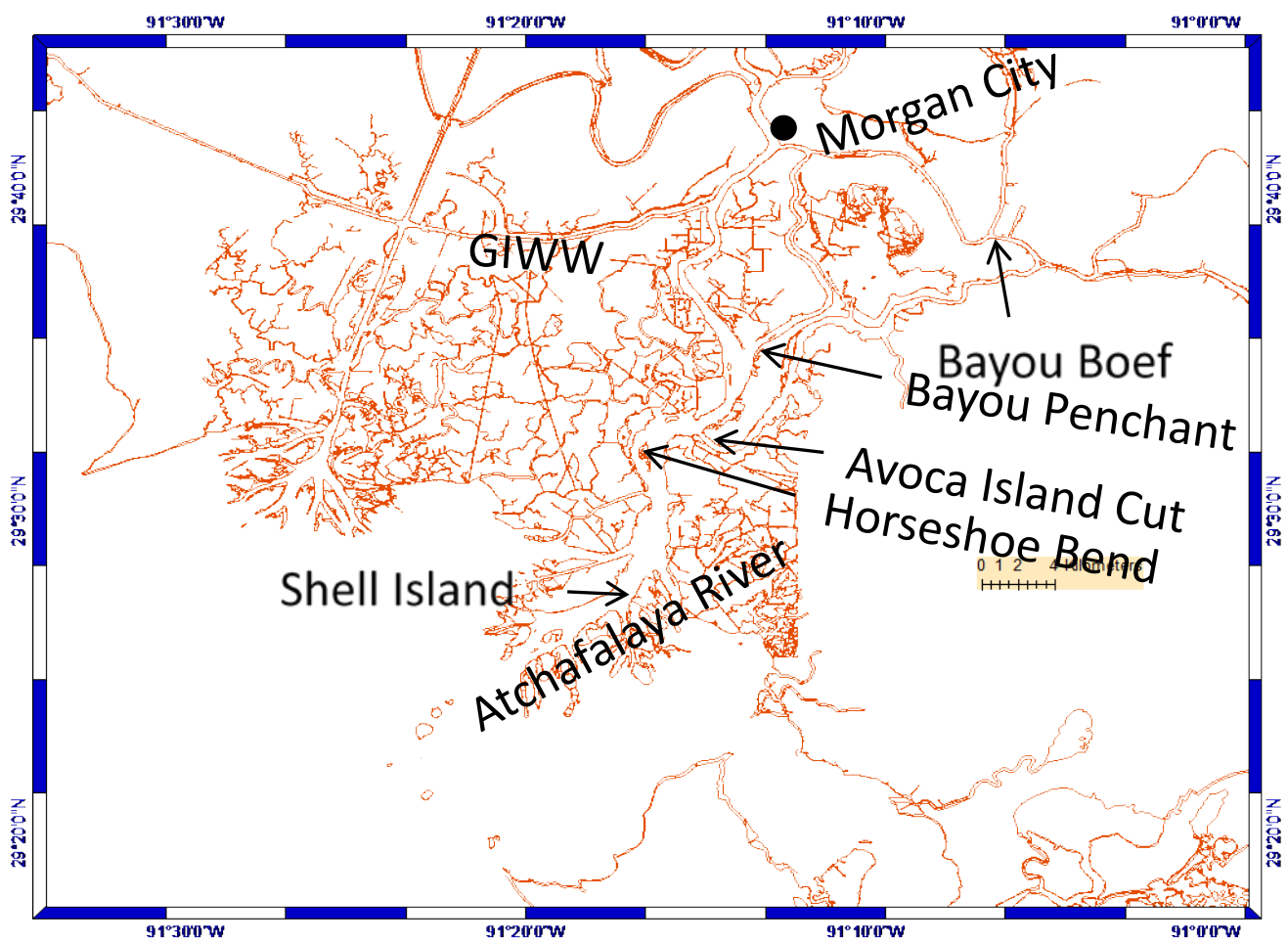

The one-dimensional sediment transport model, HEC-6T, was used to estimate the maintenance dredging requirement for $52 \mathrm{~km}$ (32.5 miles) of the Lower Atchafalaya River between Morgan City at River Mile -119 and Eugene Island at River Mile -151.5 over a 50-year period. The most critical dredging reaches are Horseshoe Bend between River Miles - 134.4 and -137.9 and the Bay Channel between River Miles -151.5 and -139.8. The study also included (1) $22.9 \mathrm{~km}$ of Bayou Chene from the Avoca Island Cutoff to the Gulf Intracoastal Waterway, (2) $2.4 \mathrm{~km}$ of Bayou Boeuf between Amelia and Bayou Chene, and (3) $5.5 \mathrm{~km}$ of Bayou Black between Bayou Chene and Bay Wallace. The two upstream boundary control points were at Morgan City on the Lower Atchafalaya River (Control Point 6) and at Amelia on Bayou Boeuf (Control Point 3). The discharge hydrograph was simulated in the numerical model by a series of steady-state events. The duration of these events was set at 1 day in the model. Mean daily flow data for water years 1998- 2002 and J anuary-J une 1975, from the USGS website (USGS 2016), were used to develop a hydrograph at the two upstream boundary points. Downstream water-surface elevations at Eugene Island and Bay Wallace were used as boundary conditions in the numeri- 
cal model. The downstream water surface elevation was set based on existing mean annual values. Starting water-surface elevations were increased over time to simulate estimated delta growth.

As part of the Dredged Material Management Plan in force, the USACE New Orleans District studied the relocation of the authorized Federal channel through Horseshoe Bend. The proposed relocation of the channel to the east at Crewboat Cut can reduce maintenance dredging by over 0.76 million $\mathrm{m}^{3}$ /year. A two-dimensional model, RMA-2, was developed to simulate three Atchafalaya River flow conditions. The changes in velocities were analyzed to determine potential impacts of relocating the channel. Sediment transport was also simulated to study erosion and deposition. The second model uses the model's grid and bathymetry data for defining the boundary conditions.

To assess the formation of the Horseshoe Bend Island in the Atchafalaya River, the U.S. Army Engineer Research and Development Center (ERDC) developed a hydrodynamic model to gain an understanding about how the island footprint is growing and to serve as input into models determining the transport of sediments from dredged material seed mounds to the island. The model analyzed the hydrodynamics around the island and also determined sediment transport characteristics. The hydrodynamic model will help identify the processes associated with hydrodynamics and sediment transport of the island's creation and growth.

\subsection{Curvilinear Hydrodynamics in Three Dimensions (CH3D) model}

The CH3D model (Chapman et al. 1996) is based on the assumptions of hydrostatic pressure distribution, Boussinesque approximation, and the eddy-viscosity concept. It is composed of mass and momentum conservation equations. In the momentum equation, the velocity variations in time and space are dependent on Coriolis force, horizontal pressure gradients, surface and bottom stresses, and eddy viscosities. For the closure of the equations, the k- $\varepsilon$ turbulence model is solved. In the horizontal plane, the coordinates are transformed to a boundary-fitted curvilinear grid system. Vertically, sigma-stretched coordinates are used. For this simulation, calendar year 2012 was selected based on data availability. The first 9-month period includes wet spring and dry summer conditions and associated meteorological events. 
The solutions are controlled by bathymetry and are subject to boundary conditions especially for barotropic response. The following sections describe the model grid and boundary conditions that were used.

\subsubsection{Computational grid}

From the National Oceanic and Atmospheric Administration (NOAA) Electronic Navigation Chart (ENC), 5800 sounding data points were extracted for use in the present study (Figure 25). The data were obtained over a 70-year period between 1935 and 2006 and may not reflect the most up-to-date bathymetry data. The existing RMA-2 model grid also contains bathymetry data (Figure 26). Note that NOAA sounding data units are in meters whereas the RMA- 2 bathymetry data are in feet. Overall, the depths between NOAA ENC and RMA data are in agreement. Figure 27 shows the portion of RMA-2 grid overlaid at the Horseshoe Bend Island and vicinity. The highest grid resolution is about $50 \mathrm{~m}$ near the Horseshoe Bend Island. In general, the channel resolution is about 50$100 \mathrm{~m}$ whereas low resolution of about $1800 \mathrm{~m}$ was applied near the open boundary grid. The total number of nodes was 12,314.

Figure 25. Sounding data from NOAA's Electronic Navigation Chart (units in meters).

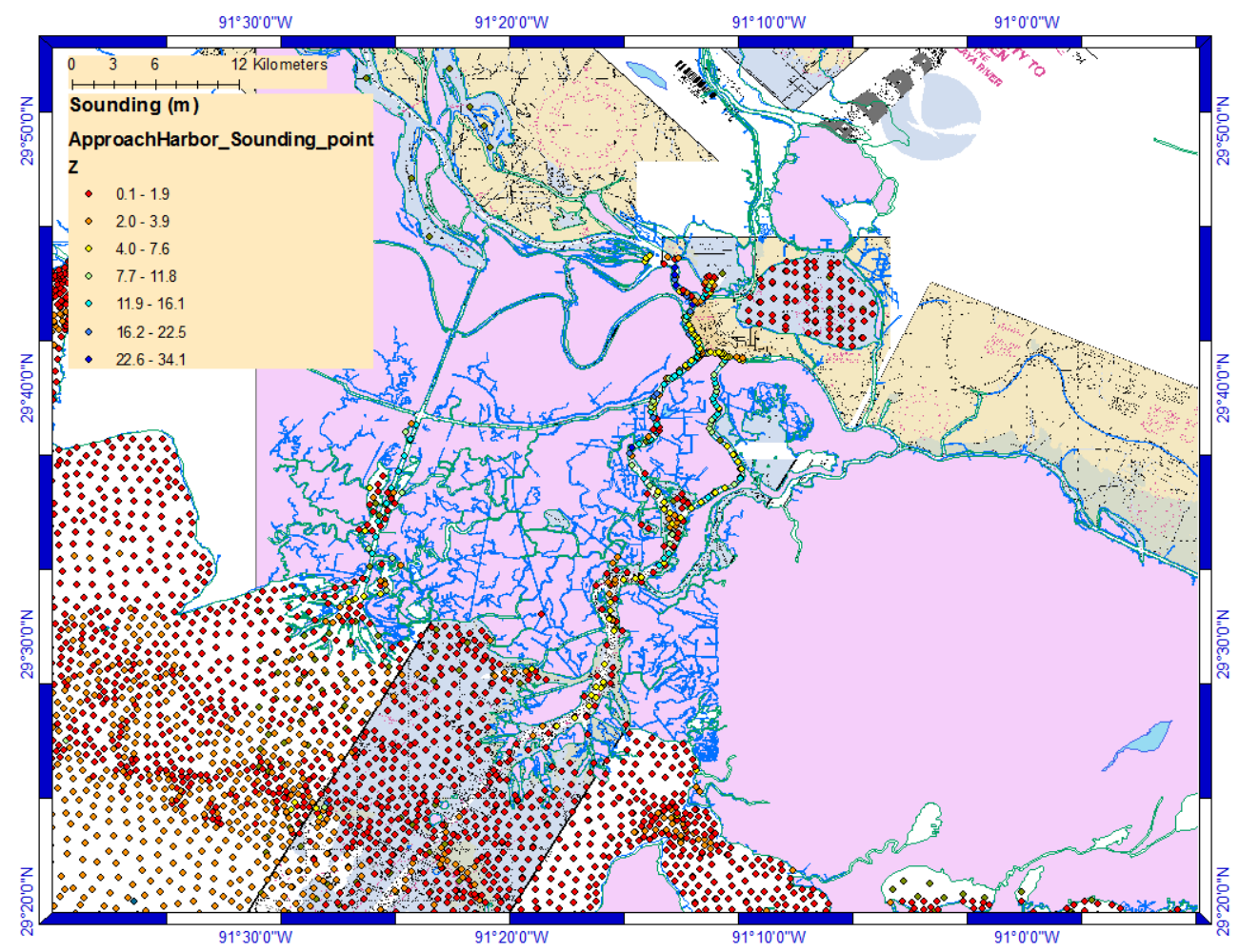


Figure 26. RMA-2 grid with bathymetry data (units in feet).

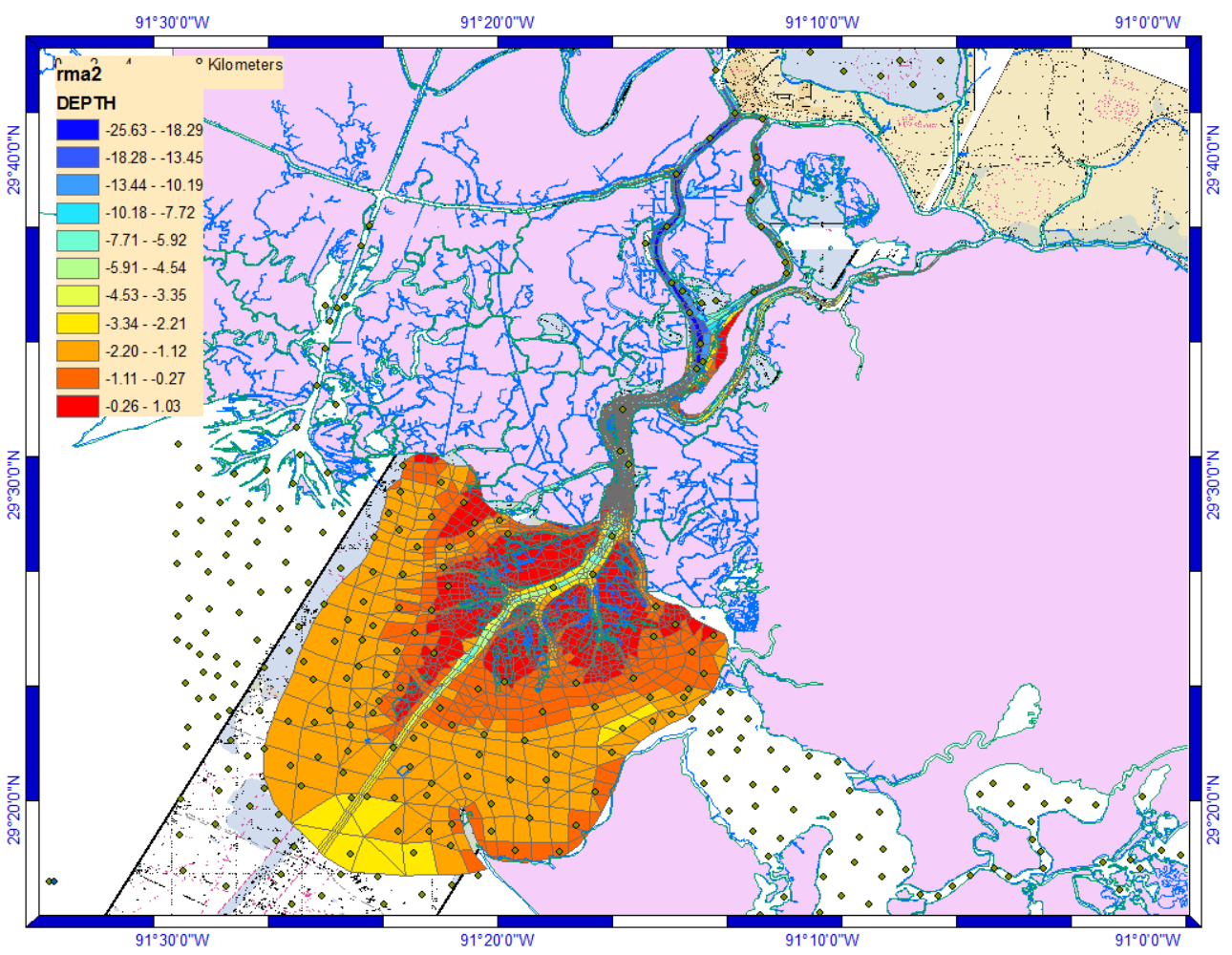

Figure 27. The RMA-2 grid overlaid in the vicinity of the Horseshoe Bend Island.

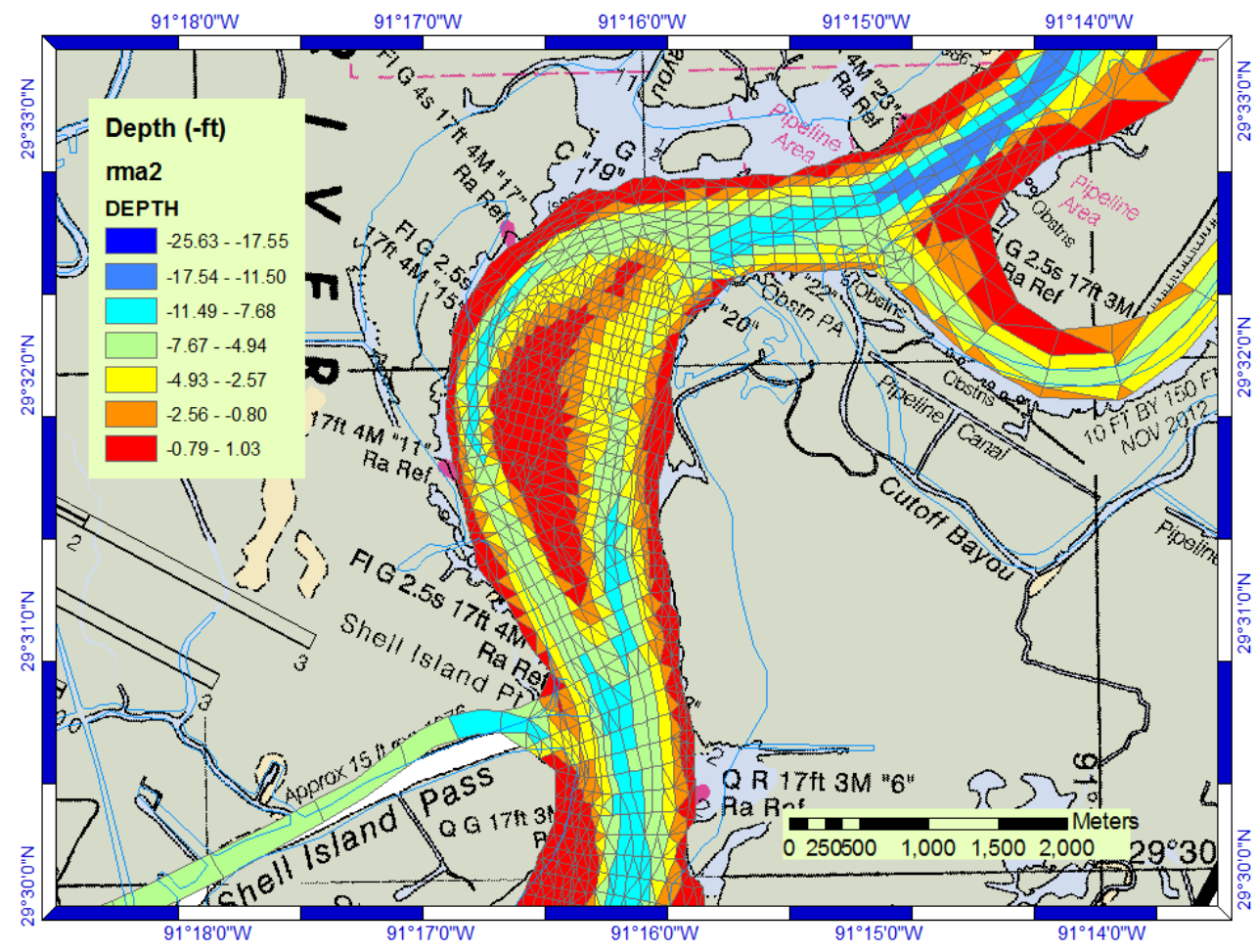


The domain for the current CH3D model was set comparable to the RMA2 model domain in plan view (Figure 28). The resolution at the focus area around Horseshoe Bend Island is roughly $50 \mathrm{~m}$ (Figure 29). The CH3D grid cell dimension is 104 by 209, and the total number of surface cells is 8723. The model was set to run in three-dimension. The model is using bathymetry following vertical coordinates, which will give the same number of vertical layers all over the model domain. The number of vertical layers was set to five so that the vertical resolution for the $6 \mathrm{~m}$ channel around Horseshoe Bend becomes about $1.2 \mathrm{~m}$.

Figure 28. The RMA-2 model grid in plan view.

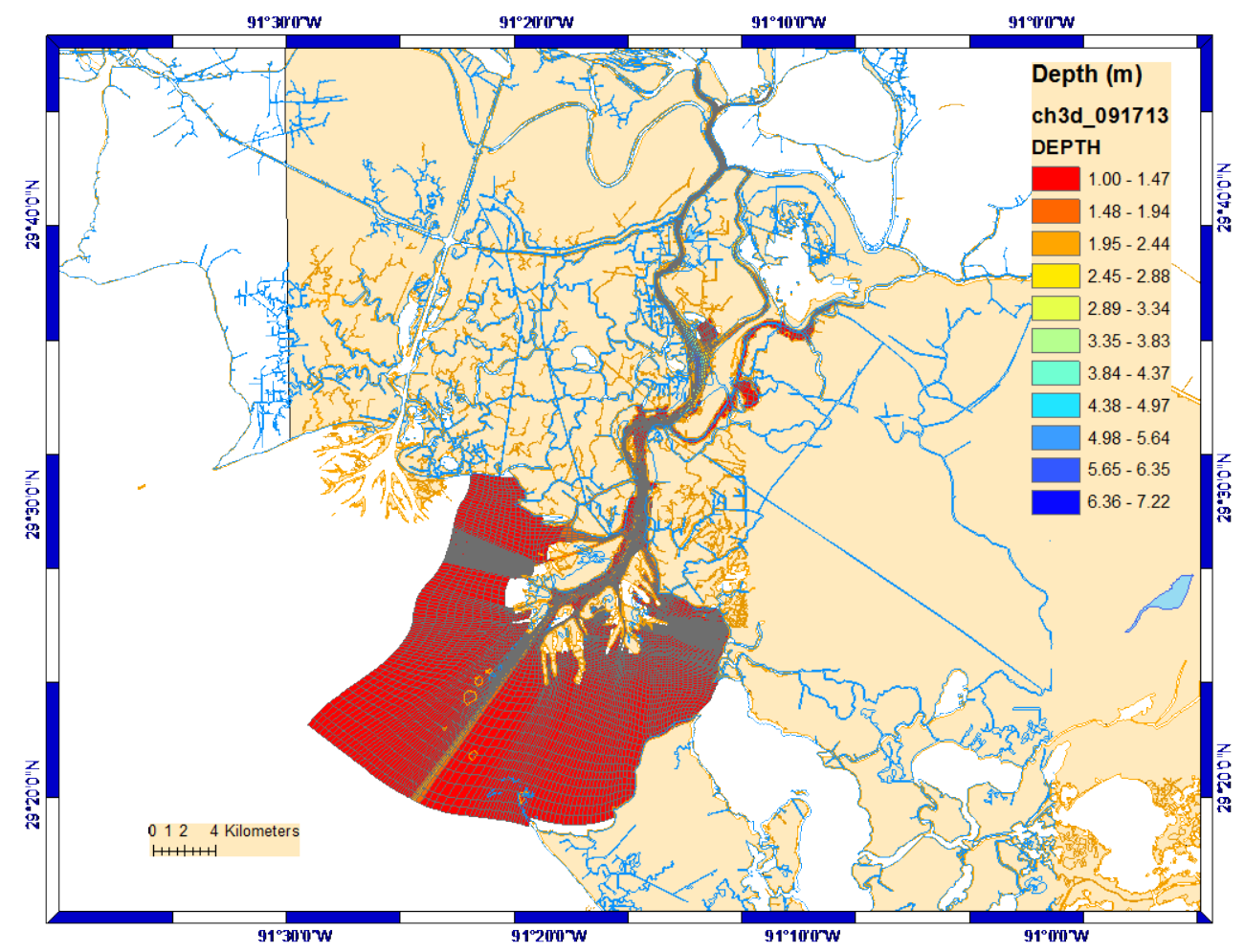


Figure 29. The $\mathrm{CH} 3 \mathrm{D}$ grid of the Horseshoe Bend Island vicinity. Depth is in meters.

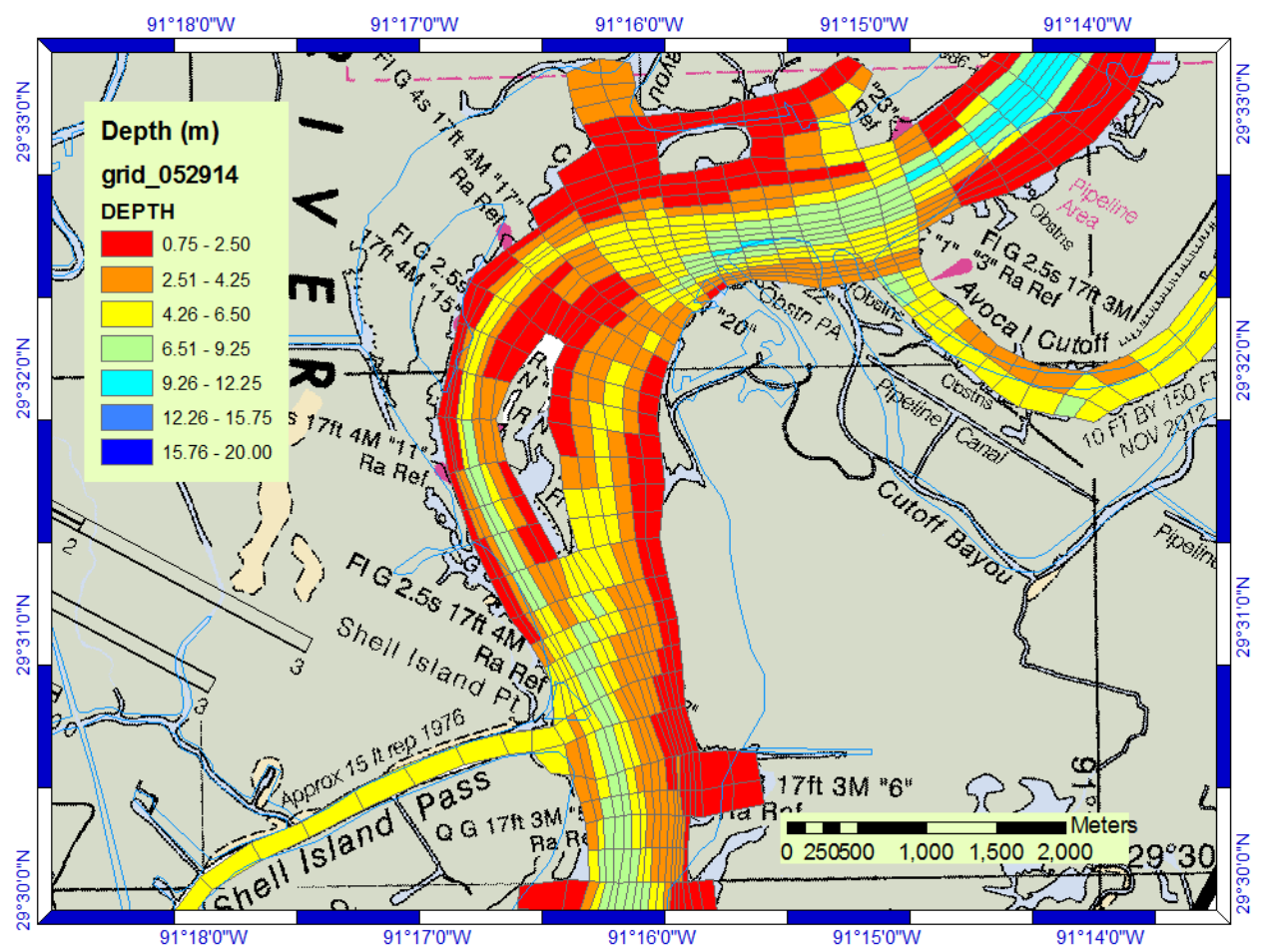

\subsubsection{Boundary conditions and forcing}

Figure 30 shows the gage locations used for providing boundary conditions and forcings to the Lower Atchafalaya River. There are two relevant NOAA tide gages in operation - one at Lawma, Amerada Pass, LA (gage number 8764227), and the other at Berwick, LA (gage number 8764044). The mean tide range is $0.34 \mathrm{~m}$ at Lawma and $0.14 \mathrm{~m}$ at Berwick. Table 16 shows the seven major tidal harmonic constituents at the Lawma gage station. Tides are dominantly diurnal in the study area.

There are seven USGS gage locations in the study area (Table 17). Of these, two stations-7381654 (Eugene Island) and 293229091230800 (CRMS0465-H01-RT) - have data that are available after March 2013. For the other five stations, data are available since water year (WY) 2008 (starting in October 2007). 
Figure 30. Gage locations for Lower Atchafalaya River. Triangles (b/ue) represent USGS gage locations, circles (purple) are for NOAA tide gage locations, and the asterisk (green) denotes a meteorological station.

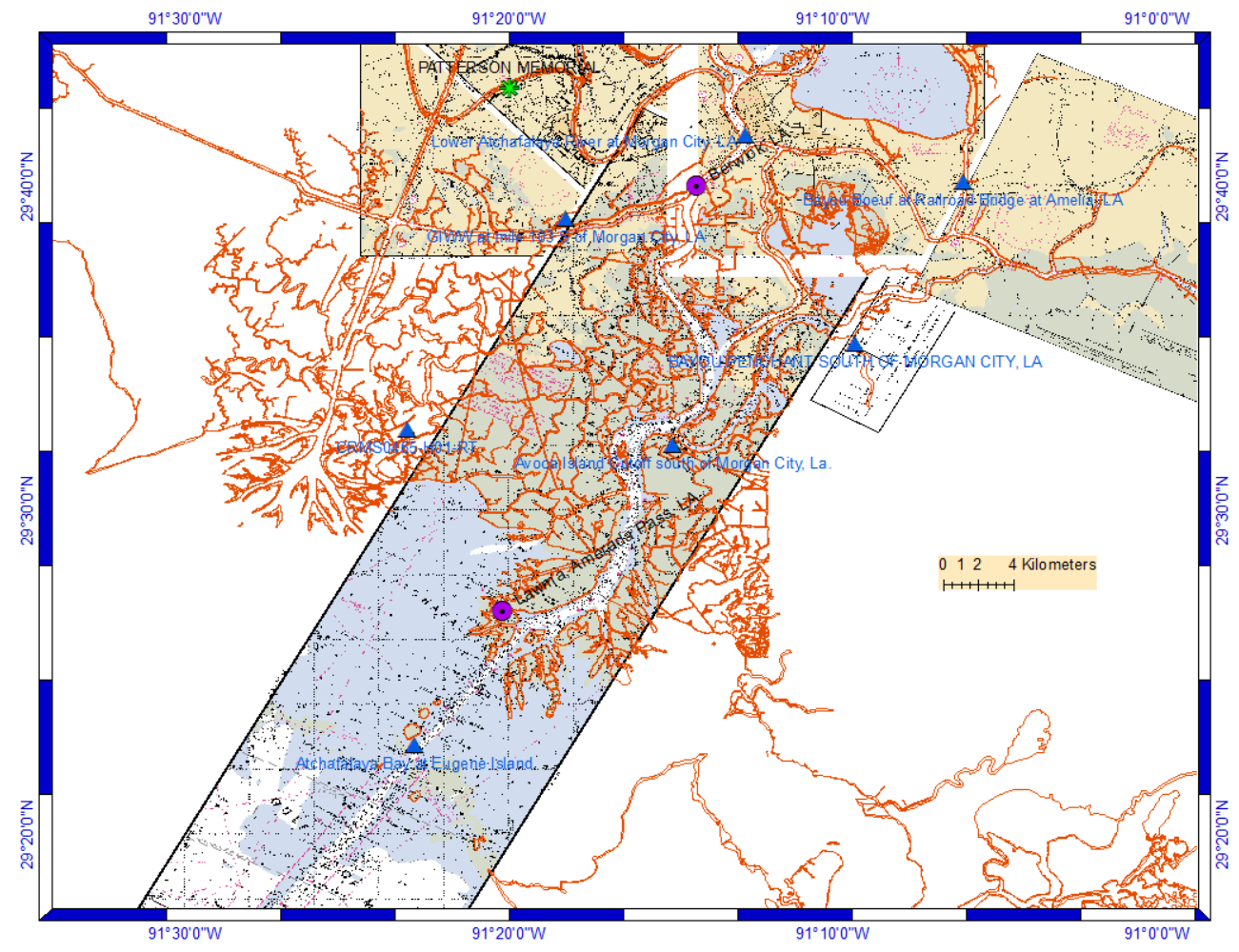

Table 16. Tidal harmonics at the Lawma gage station, LA (NOAA 2013).

\begin{tabular}{|l|c|c|l|}
\hline Constituents & Amplitude (ft) & Phase (degrees) & \multicolumn{1}{|c|}{ Description } \\
\hline K1 & 0.423 & 313.1 & Lunar diurnal constituent \\
\hline 01 & 0.377 & 312.4 & Lunar diurnal constituent \\
\hline M2 & 0.292 & 120.8 & Principal lunar semidiurnal constituent \\
\hline P1 & 0.161 & 309.5 & Solar diurnal constituent \\
\hline S2 & 0.112 & 105.9 & Principal solar semidiurnal constituent \\
\hline Q1 & 0.089 & 300 & Larger lunar elliptic diurnal constituent \\
\hline
\end{tabular}

Table 17. USGS gage locations in the study area.

\begin{tabular}{|l|l|}
\hline \multicolumn{1}{|c|}{ STID } & \multicolumn{1}{c|}{ STATION } \\
\hline 73816501 & Avoca Island Cutoff south of Morgan City, LA. \\
\hline 73814675 & Bayou Boeuf at Railroad Bridge at Amelia, LA \\
\hline 7381654 & Atchafalaya Bay at Eugene Island, LA \\
\hline 73816503 & Bayou Penchant south of Morgan City, LA \\
\hline 7381600 & Lower Atchafalaya River at Morgan City, LA \\
\hline 73816202 & GIWW at mile 103 S of Morgan City, LA \\
\hline 293229091230800 & CRMS0465-H01-RT \\
\hline
\end{tabular}


The hydrology record at the five USGS gages over the 7-year period between WY 2007 and WY 2013 shows intra- and interannual signals (Figure 31). Gages along the Atchafalaya River (7381600 and 73816503), the GIWW (73816202), and Bayou Boeuf (73814675) exhibit similar hydrological responses. The maximum gage height variation in the upstream station (7381600) is about $3.0 \mathrm{~m}$ whereas it is about $1.5 \mathrm{~m}$ about $20 \mathrm{~km}$ downstream (73816503). Overall, these gage data indicated that WY 2011 was a wet year and WY 2012 was a dry year.

Figure 31. Gage heights from USGS gages over the 7-year period between water years 2007 and 2013. Gages are 7381600 (upper left panel), 73816202 (lower left panel), 73814675 (upper right panel), and 73816503 (lower right panel).
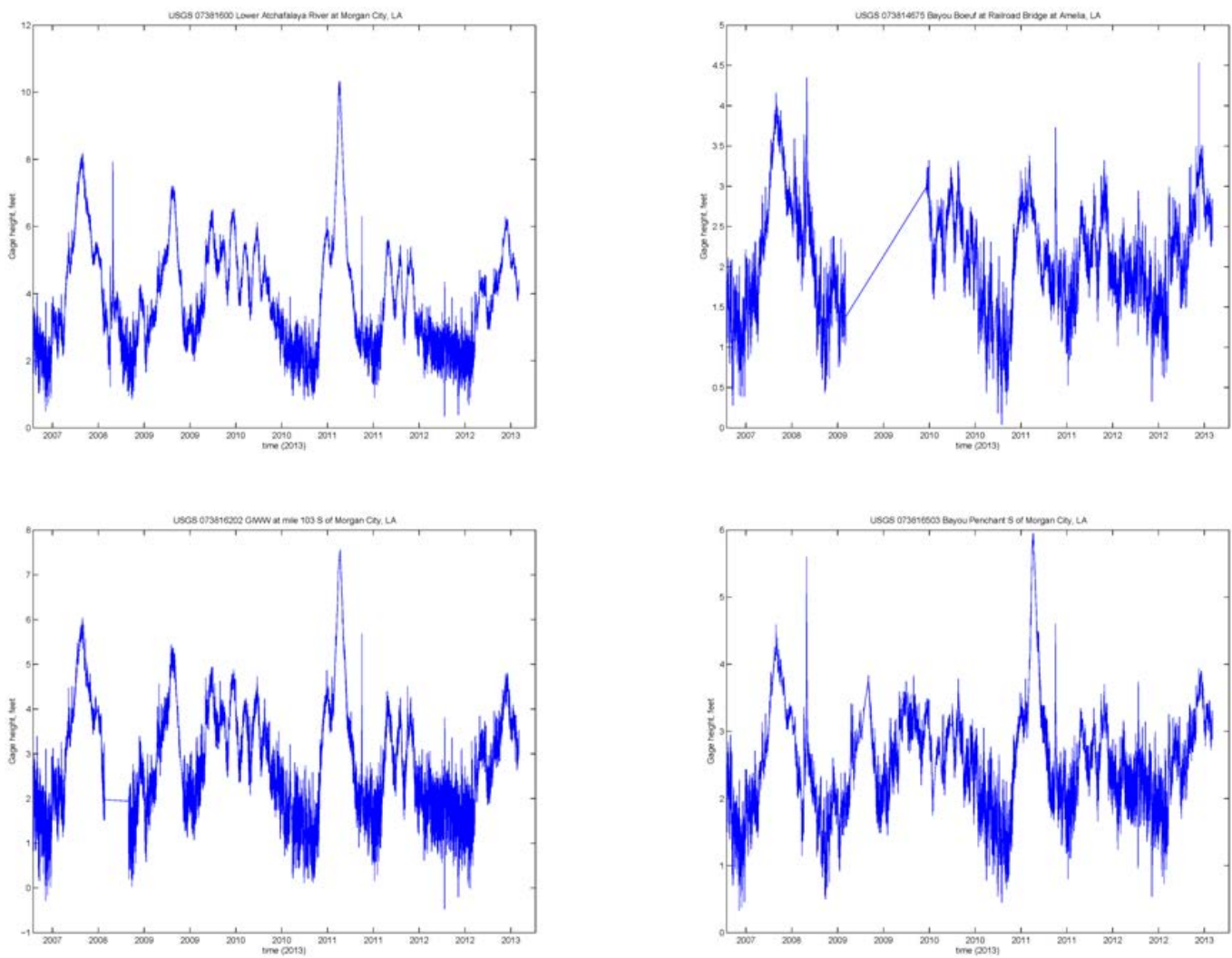

To assess intra-annual variability, the 2012 water level data from USGS gage at upstream (7381600) was compared with NOAA tide data from upstream (8764044) and downstream (8764227) gages (Figure 32). Persistent hydrological input over April was observed. Meteorological conditions were observed by using wind speed and surface pressure data. A meteoro- 
logical event associated with passage of a low-pressure system on 4 September 2011 resulted in a high-water-level event of about $1.5 \mathrm{~m}$ (Figure 33, lower left panel).

Figure 32. Intra-annual variability of the hydrology record across select USGS and NOAA gages for water year 2012. Shown are gage height (ft) for USGS gage 7381600 (upper left panel), and for NOAA gages 8764044 (b/ue) and 8764227 (green), water levels (m; lower left panel), surface pressure (mb, upper right panel), and wind speed (m/s; lower right panel).
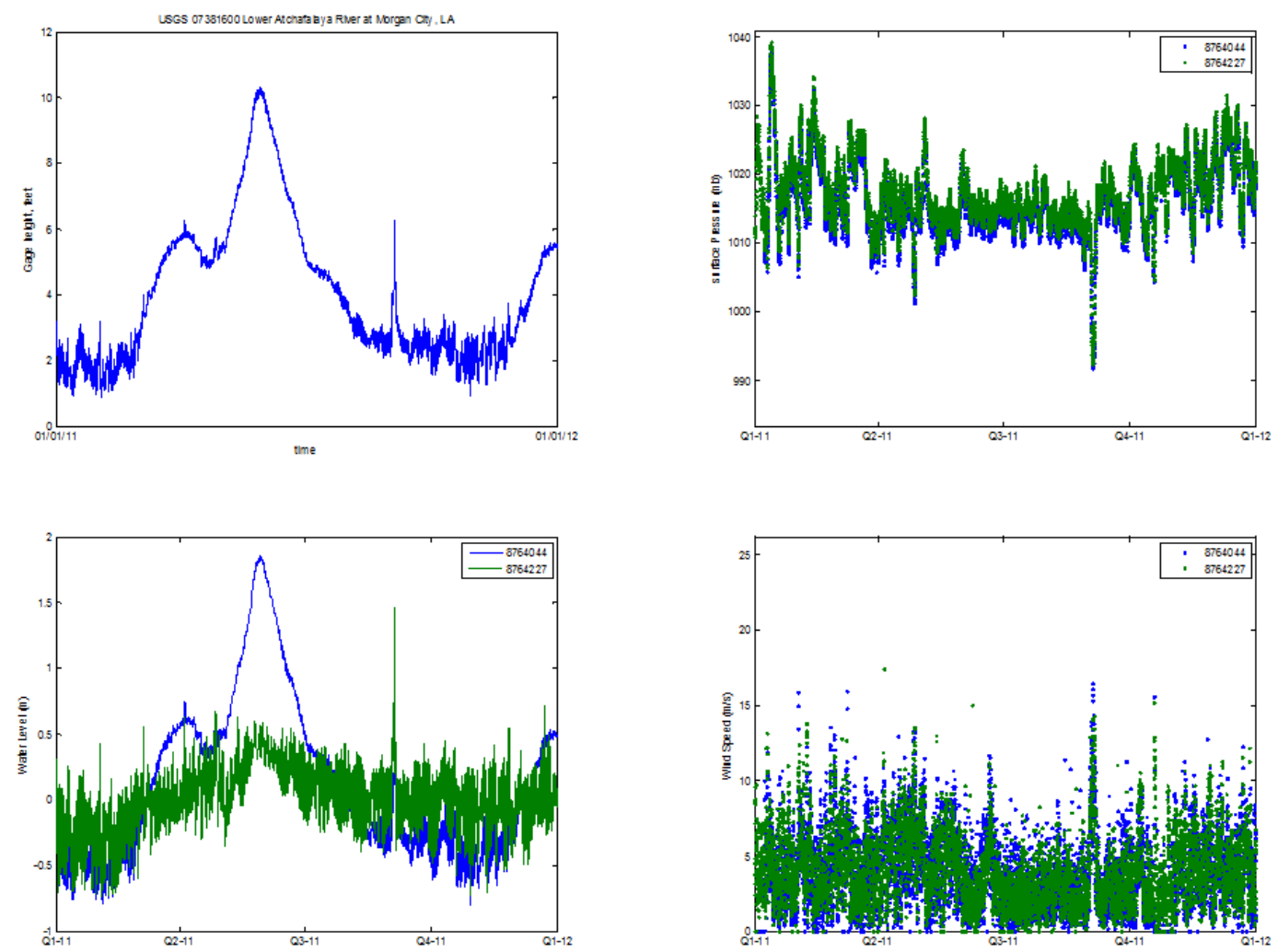

Figure 33. Flow boundary conditions in 2012 using data from three USGS gage stations.

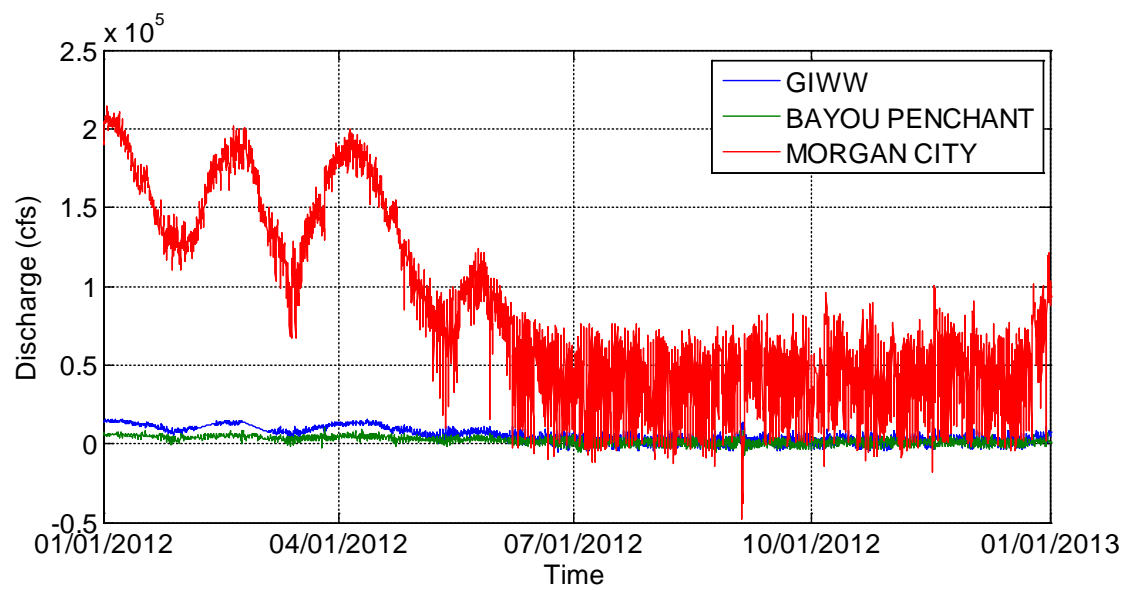


The upstream flow boundary was set near Morgan City by using data from USGS gage 7381600. Other flow boundary conditions were set at GIWW and at flows from the east via Bayou Penchant and the Avoca Island Cutoff. Figure 34 shows flows at the three boundaries, indicating that the flows at Morgan City dominate the system.

Figure 34. Seven locations (green triangles) used for obtaining water level data along the open boundaries. The green circle near the entrance of Atchafalaya River marks the location of NOAA gage 8764227.

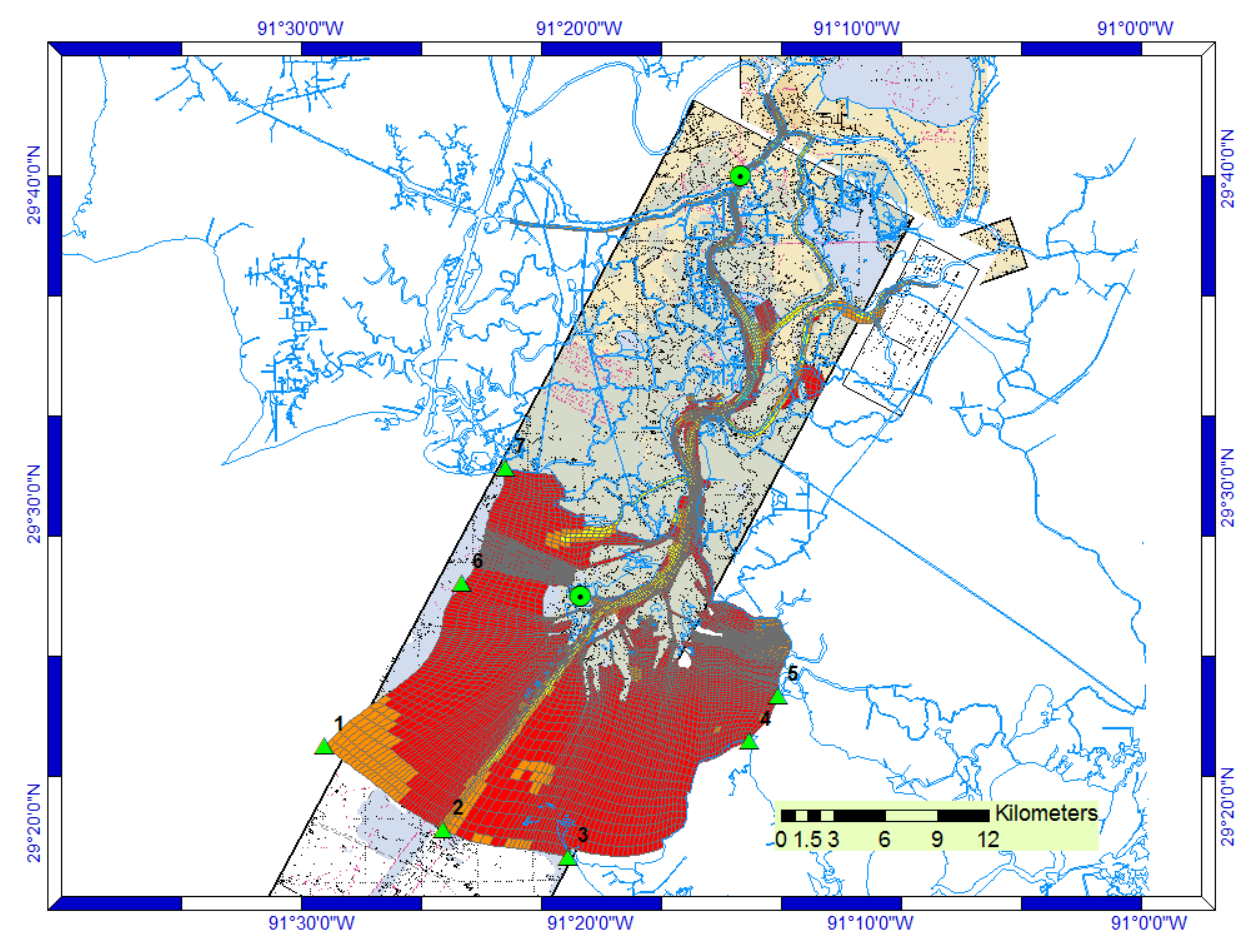

Water levels were set using seven points along the open boundaries (Figure 35). The relationships of amplitude and phase between each location and NOAA gage 8764227 were obtained from published tide tables. Figure 36 shows the water levels at NOAA gage 8764227. The gap in data indicates a 10-day period between 6 November 2012 and 16 November 2012 when data were unavailable. These data indicate six meteorological events: 18-Feb-2012 20:00:00; 21-Mar-2012 14:00:00; 04-Apr-2012 20:00:00; 19-Aug-2012 11:00:00; 29-Aug-2012 05:00:00; and 30-Aug-2012 20:00:00. J uly appears to be quiescent in terms of meteorological forcing. Figure 37 shows wind speed and direction observed at NOAA gage 8764227. The plot indicates strong winds associated with a frontal passage is related to a 1-day event between 19 and 29 August 2012. It also suggests 
a persisting southwest wind caused surges in water levels around 21 March 2012.

Figure 35. Water levels at NOAA gage 8764227 for 2012 that identified six meteorological events in the study area.

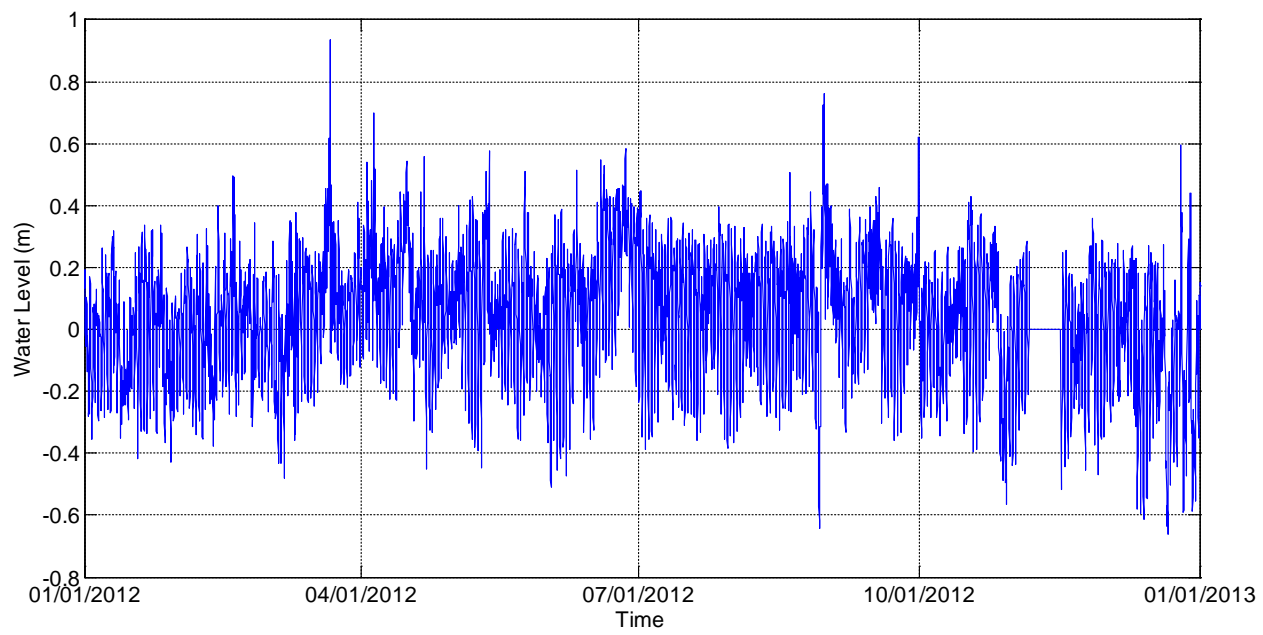

Figure 36. Wind speed (top pane) and direction (bottom pane) at NOAA gage 8764227.
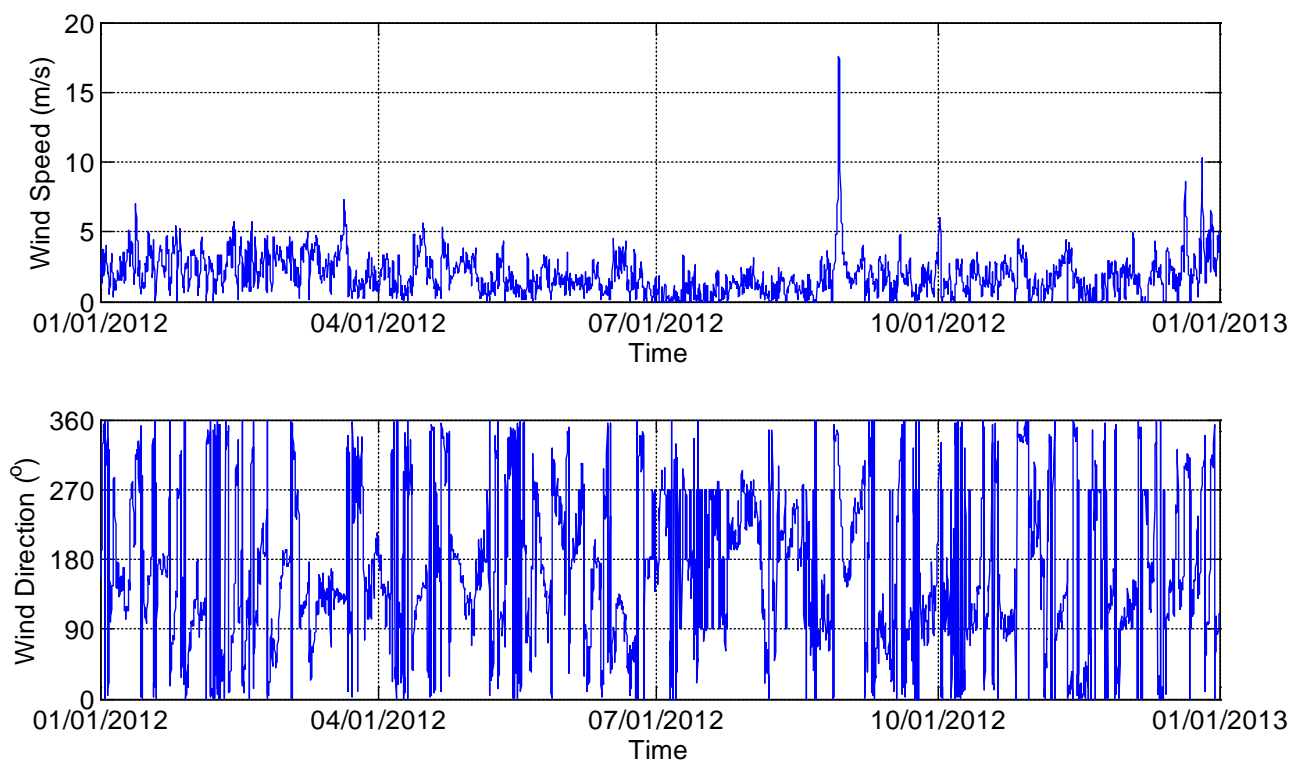
Figure 37. Predicted (red lines) and observed (blue dots) hourly water levels for the first 4 months of 2012 at NOAA gage 8764044 at Berwick, LA, and NOAA gage 8764227 at Lawma, LA.
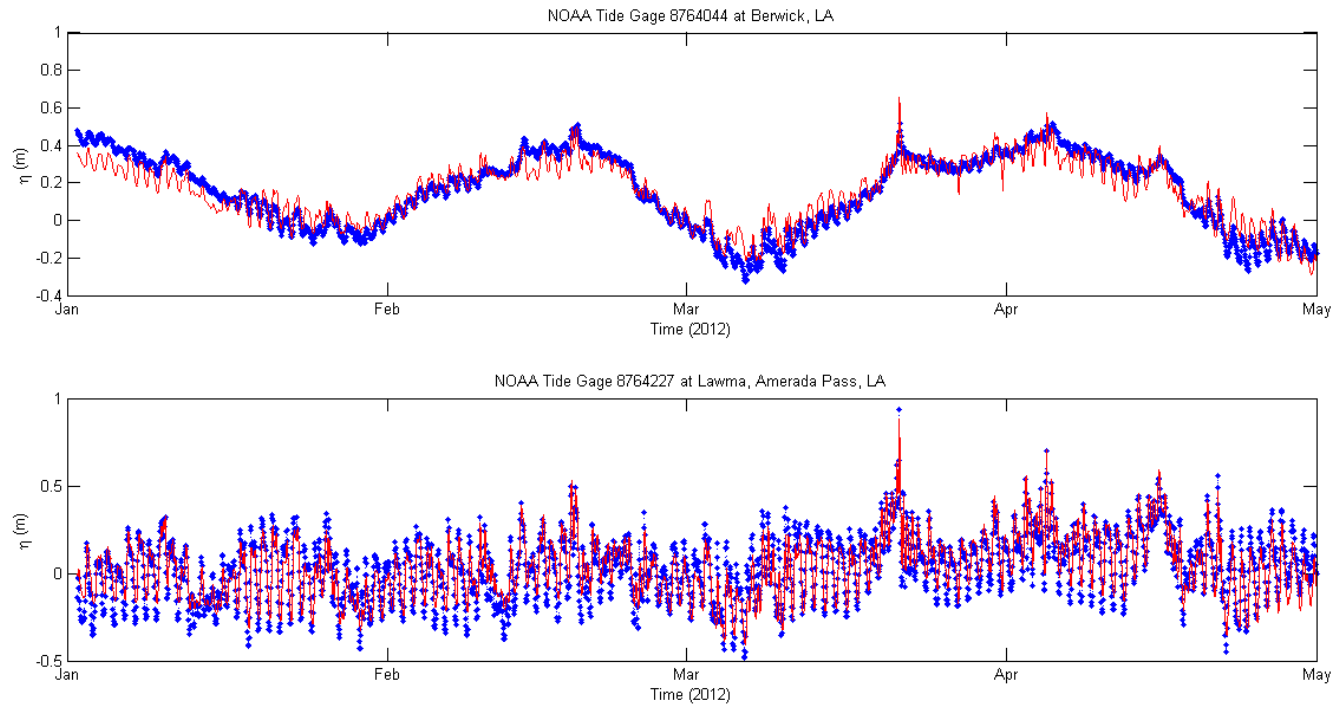

\subsubsection{Model calibration results}

Water levels at two tide gages, one at NOAA gage 8764044 at Berwick, LA, and NOAA gage 8764227 at Lawma, LA, were compared, showing the predicted water levels against observed hourly water levels at these two locations (Figure 37). The predicted water levels resolve tidal signals and subtidal signals for meteorological events. There are no other observed data for water levels nor are currents available to validate the model. Further calibration and validation of the model will require additional field data from the study area.

\subsection{General Transport Model (GTRAN)}

The GTRAN model uses near-bottom velocities from the CH3D model and calculates transport rates of both suspended load and bedload transport. The calculation also depends on bed characteristics obtained from the study area. Points depicting sediment data sources are shown on the CH3D model grid in Figure 38. Surface sediment grain size data were analyzed and assigned to CH3D model grid cells (Figure 39). Figure 40 shows the median grain size interpolated over the model grid around Horseshoe Bend. Northwest of the island and along the flank of the island, coarse bottom sediments prevail (sands) whereas the northern end of the island is comprised of fine-grained sediments (silts and clays). 
Figure 38. Median grain size of bottom sediments in the study area.

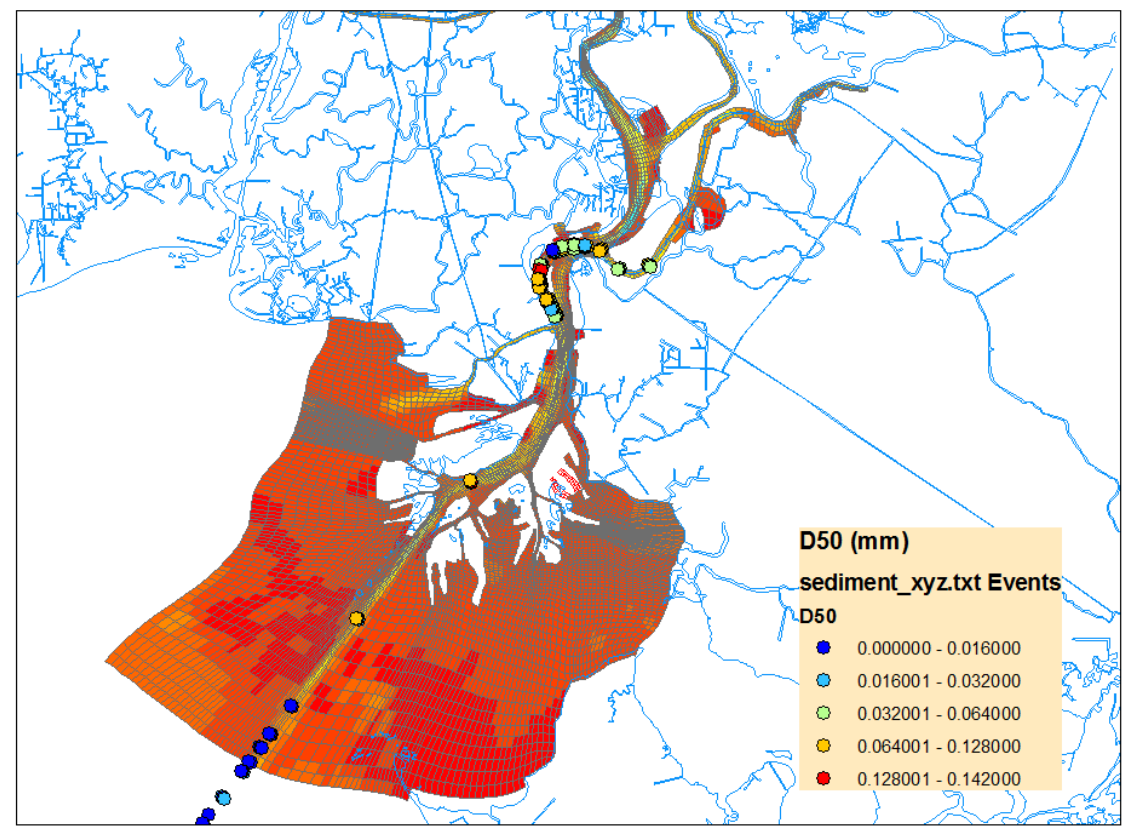

Figure 39. Assigned median grain size based on existing data shown in Fig. 40.

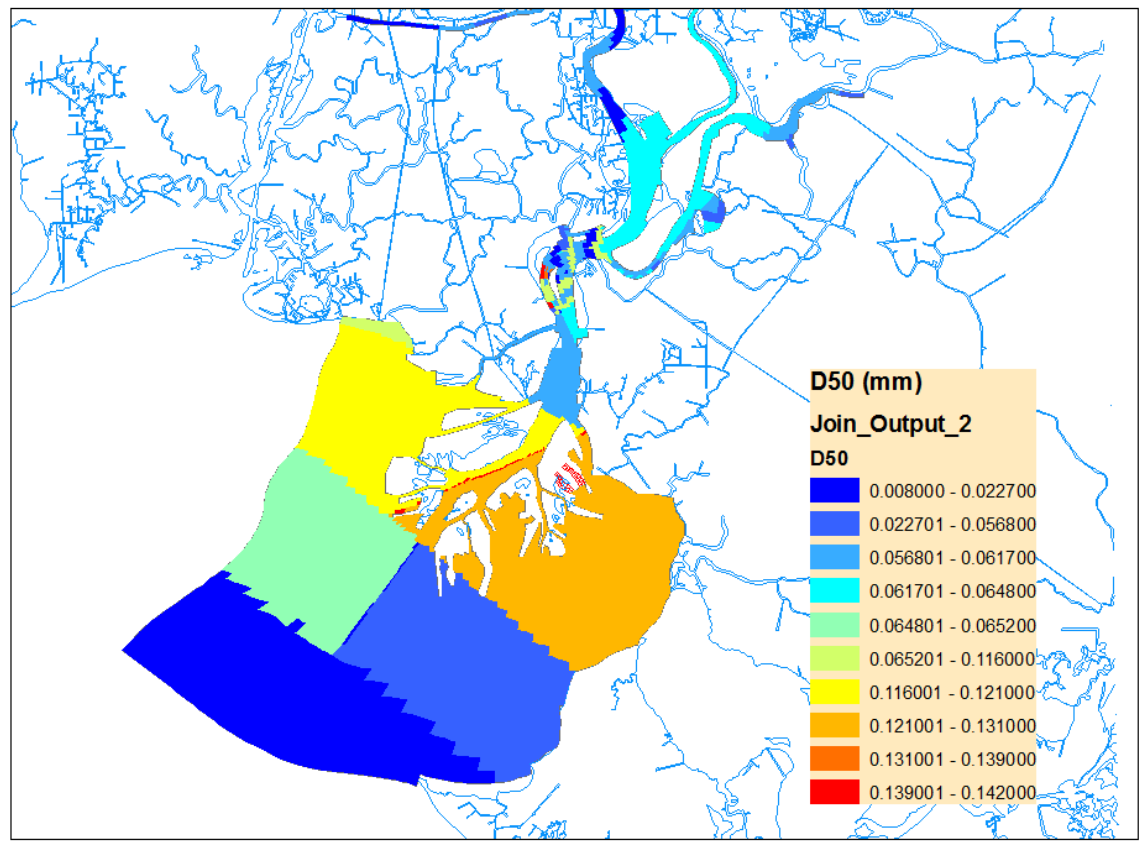


Figure 40. Assigned median grain size to $\mathrm{CH} 3 \mathrm{D}$ model grid.

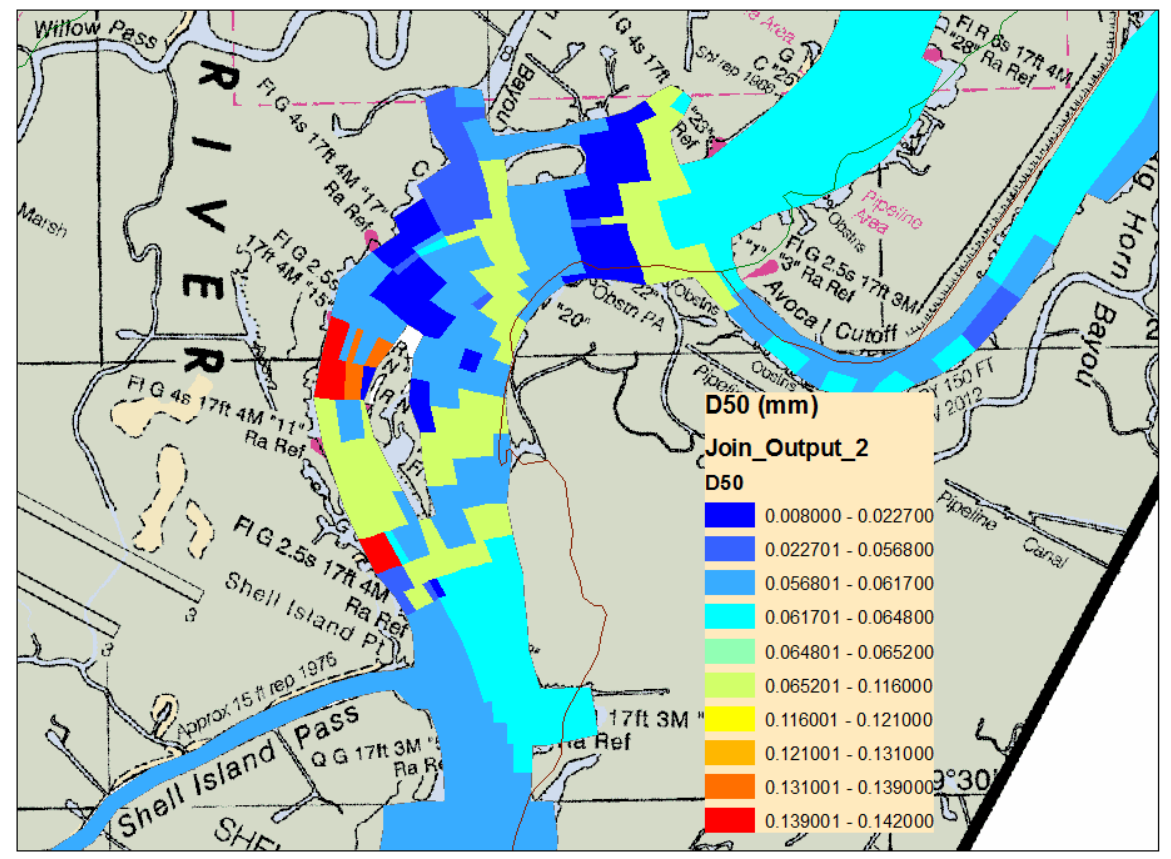

Bottom currents vary with the hydrological cycle. The wet season from J anuary through March 2012 shows much stronger bottom currents (Figure 41; maximum about $1.44 \mathrm{~m} / \mathrm{s}$ ) around the island than the dry season from J uly through September 2012 (Figure 42; maximum about $0.47 \mathrm{~m} / \mathrm{s}$ ). Both suspended load and bedload transport is controlled by bottom currents and by bottom sediment grain size. Typically, the suspended sediment transport rate is an order of magnitude higher than bedload transport. The maximum volume transport rate during the wet season is about $9.66 \mathrm{~m}^{3} / \mathrm{m} / \mathrm{s}$ as suspended load and about $0.71 \mathrm{~m}^{3} / \mathrm{m} / \mathrm{s}$ as bedload. These rates decrease during the dry season $-1.50 \mathrm{~m}^{3} / \mathrm{m} / \mathrm{s}$ as suspended load and $0.11 \mathrm{~m} / \mathrm{m} / \mathrm{s}$ as bedload. Figures 43 and 44 show the mean transport rates during the wet season for suspended sediment and bedload transport, respectively, and indicate possible deposition toward the northeast shore and erosion from the southeast shore of Horseshoe Bend Island. 
Figure 41. Mean bottom current during the relatively wet season from January through March 2012.

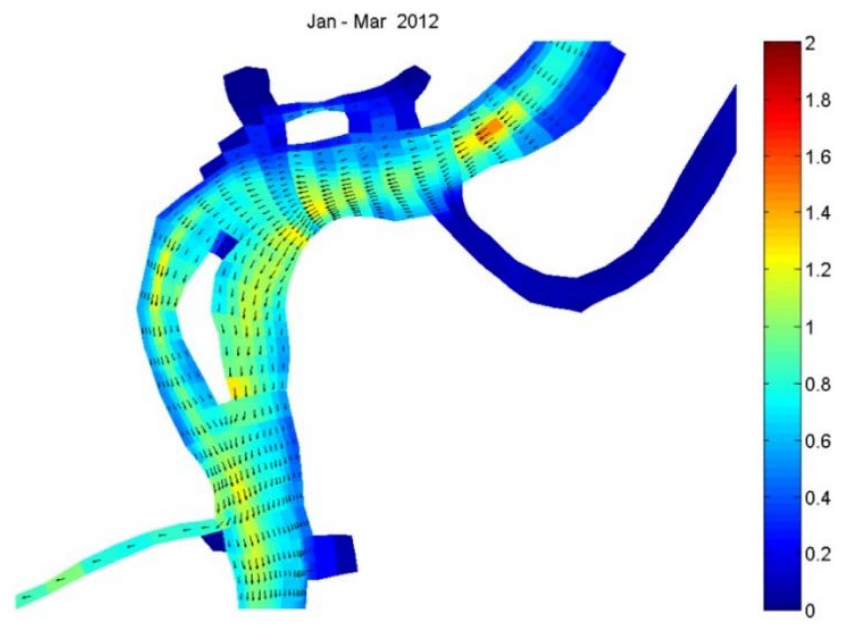

Figure 42. Mean bottom currents during the relatively dry season from July through September 2012.

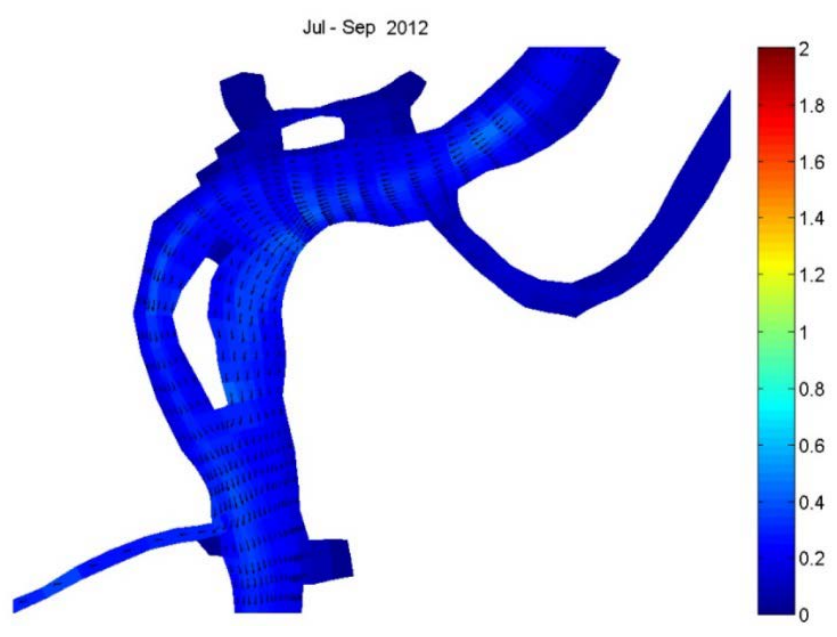

Figure 43. Mean suspended sediment transport rate from January through March 2012.

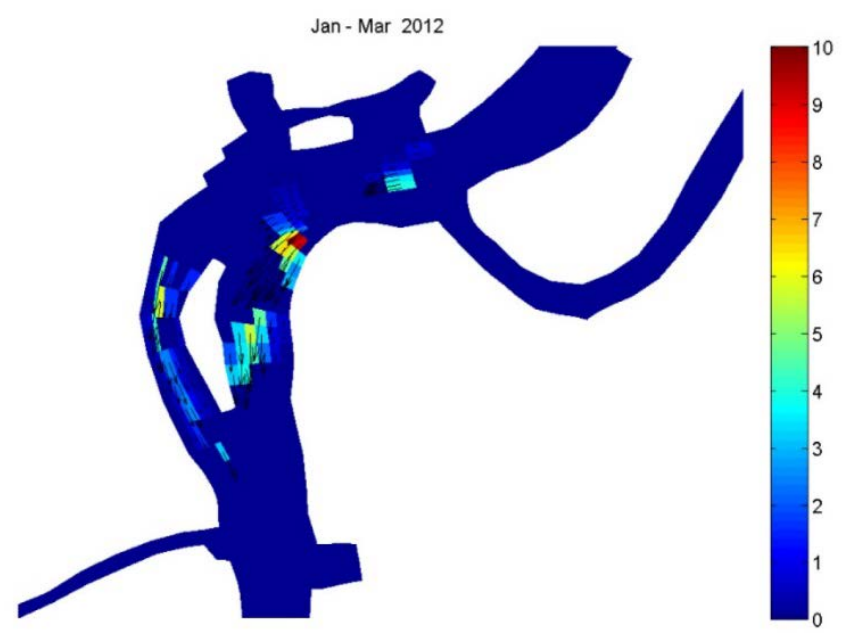


Figure 44. Mean bedload transport rate from January through March 2012.

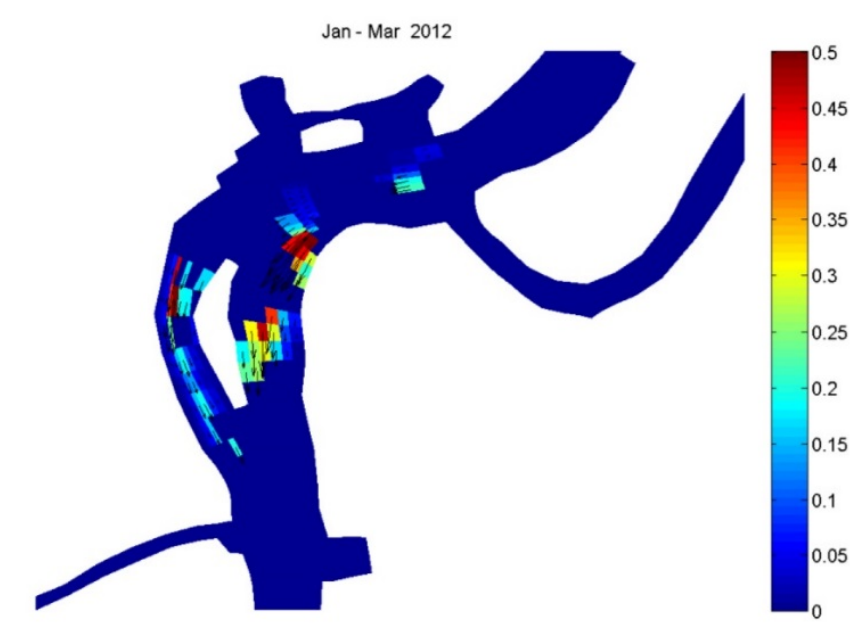

\subsection{Conclusions}

A three-dimensional hydrodynamic model, CH3D, was applied to the Lower Atchafalaya River and adjacent Atchafalaya Bay to assess the formation of the Horseshoe Bend Island in the Atchafalaya River to gain a more complete understanding how the island footprint is being created. A one-year simulation during water year 2012 showed the hydrodynamic model behavior is strongly related to hydrological forcing. A sediment transport model, GTRAN, was linked to CH3D to estimate sediment transport rates. The results indicated dynamic response of sediment transport during the wet season extending from J anuary to March and indicated along the eastern shore of Horseshoe Bend Island possible deposition toward the northern shore and erosion from the southern shore. To a lesser degree, the western shore of the island showed erosion along the northern shore and deposition along the southern shore. The model will require more hydrodynamic and sediment transport data from the area to calibrate and validate. Nonetheless, these model results can serve as valuable information so that this innovative and strategic use of dredged sediment can be applied in other island building projects. 


\section{Discussion and Conclusions}

Landin (1989) identified over 100 reports examining wetland creation with dredged material, and dozens more have been published since on this topic. The majority of these studies focus on marsh creation, including information on engineering aspects of dredged material placement and vegetation establishment and comparisons of select ecosystem components between natural and created wetlands (Woodhouse 1979; Knutson 1977; USACE 1986; Webb 1982; Webb and Newling 1985). For example, Broome et al. (1986) evaluated vegetation establishment and trajectory, Kurz et al. (1998) compared fish populations in natural and created wetlands in Florida, and Cammen (1976) examined invertebrate community colonization in created wetlands. Although these studies provide valuable data, the focus on a single ecological factor (e.g., fish) limits the utility of these assessment results. Several studies examined a combination of ecosystem factors to expand the scope of the assessment approach. For example, Craft (2000) examined both invertebrate populations and soil characteristics (e.g., nutrients and bulk density) in natural and restored areas while Alphin and Posey (2000) combined vegetation and invertebrate data sets collected in created marshes.

Streever (2000) presents a review of dredged material supported wetlands, investigating how the success of wetland creation projects should be determined. In that study, the author combines results of a number of previously published studies to examine a variety of factors, including aboveand below-ground biomass, invertebrate communities, crustacean communities, and soil characteristics (e.g., organic carbon content). As a result, Streever (2000) presents one of the most comprehensive ecosystem assessments regarding dredged material created wetlands; however, as Streever indicates, the variety of data collection techniques used in the published studies poses challenges to comparative data interpretation.

As a result, the current study applied a multifactor ecosystem assessment of dredged material supported wetlands. Assessment factors included (1) landscape geomorphology, (2) ecosystem classification, (3) floral communities, (4) avian communities, (5) aquatic invertebrates, (6) soils and biogeochemical activity, and (7) hydrodynamic and sediment modeling. By examining ecological components comprising primary producers, microbial communities, invertebrates that form the basis of aquatic food webs, 
and higher organisms, the current study provides a comprehensive approach to the assessment of dredged material supported wetlands (Figure 45). The current study provides a framework for future studies examining the ecological, societal, and economic value of the strategic placement of dredged material applied in this manner. The multifactor-assessment approach used in the current study allows for a comprehensive analysis of ecosystem condition across of range of ecosystem components. Study results demonstrate that each of the factors examined at Horseshoe Bend Island proved comparable or exceeded the other study areas examined, including the naturally formed Middle Island and the traditionally created dredged material supported Island E. Therefore, the novel dredged material placement approach used in the creation of Horseshoe Bend Island could be applied in other scenarios to investigate the success and potential benefits of EWN projects that use natural process in such a manner to improve wetland creation and restoration outcomes.

Figure 45. Conceptual model of the multifactor-assessment approach applied at Horseshoe Bend Island.

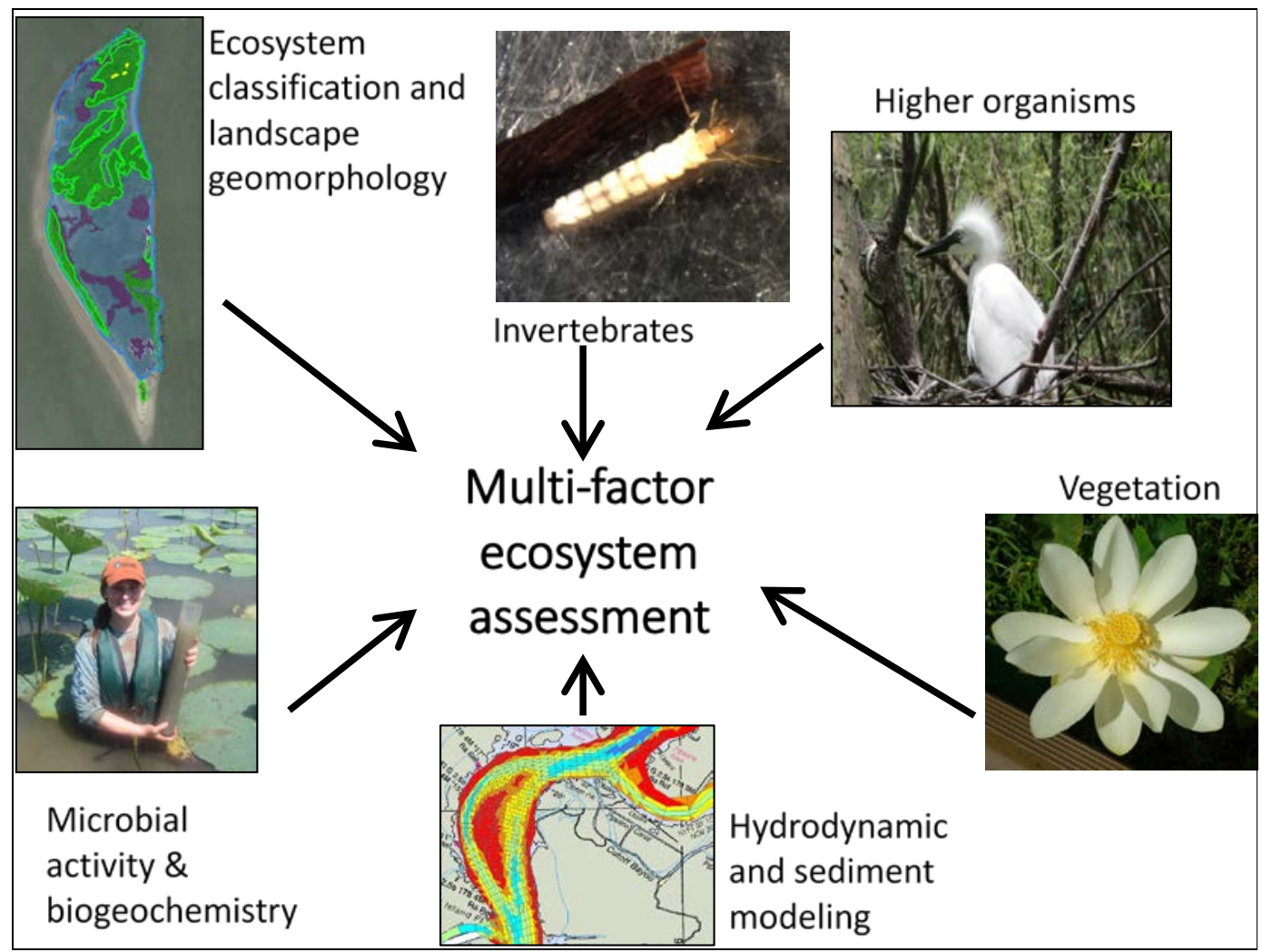

Examining each ecosystem factor, results indicate that Horseshoe Bend Island provides habitat and biogeochemical functions at rates comparable or 
exceeding those at a traditional dredged material supported island and a natural reference island. First, wetland classification and analysis of geomorphic features demonstrated that Horseshoe Bend Island provides a variety of habitat types supporting complex communities of vegetation, invertebrates, soil microbes, and higher organisms (i.e., avian species). The distribution of forested, scrub-shrub, emergent, and emergent aquatic bed habitat types corresponds to the natural distribution reported throughout the study area (University of New Orleans 2002). Second, Horseshoe Bend Island contains a wide variety of vegetation, including more than $85 \%$ native species, with species-richness values exceeding observations from both traditional dredged material supported and natural reference areas. Third, the EWN design used at Horseshoe Bend Island resulted in landscape and landform characteristics (e.g., distance from shore and flooding regime) that support a large, successful wading-bird rookery. Fourth, Horseshoe Bend Island supports more invertebrate abundance and diversity than natural islands in the region that lack the emergent aquatic bed landforms resulting from the strategic placement of dredged materials. Finally, the soils at the Horseshoe Bend Island display a capacity to sequester nutrients and other compounds and to perform water quality functions at levels comparable to natural wetlands in the region.

Further research is required to verify the results described herein and to expand the multifactor-assessment approach to other environmental settings. Additionally, increasing the number of observations and study sites promotes confidence in study results while addressing any potential autocorrelation associated with ecosystem assessments in which a small number of manipulated study sites are compared with natural reference areas (Hurlbert 1984). The application of the multifactor-assessment approach to additional ecosystem types and components will help assess the success of wetland creation and restoration practices using both traditional and EWN applications. 


\section{References}

Alphin, T. D., and M. H. Posey. 2000. Long-Term Trends in Vegetation Dominance and Infaunal Community Composition in Created Marshes. Wetlands Ecology and Management 8:317- 325.

Andersen, J . 1976. An Ignition Method for Determination of Total Phosphorus in Lake Sediments. Water Research 10:329-331.

Barras, J., S. Beville, D. Britsch, S. Hartley, S.Hawes, J . J ohnston, P. Kemp, Q. Kilner, A. Martucci, J. Porthouse, D. Reed, K. Roy, S. Sapkota, and J . Suhayda. 2003. Historical and Projected Coastal Louisiana Land Changes: 1978-2050. United States Geological Survey Open File Report 03-334. Reston, VA: U.S. Geological Survey.

Beaver, D. L., R. G. Osborn, and T. W. Custer. 1980. Nest-Site and Colony Characteristics of Wading Birds in Selected Atlantic Coast Colonies. Wilson Bulletin 92:200220.

Bedford, B. L., and E. M. Preston. 1988. Developing the Scientific Basis for Assessing Cumulative Effects of Wetland Loss and Degradation on Landscape Functions: Status, Perspectives, and Prospects. Environmental Management 12 (5): 751771.

Berkowitz, J. F., N. R. Beane, D. E. Evans, B. C. Suedel, and J . M. Corbino. 2014. Preliminary Use of Strategic Placement of Dredged Sediment to Support Horseshoe Island in the Atchafalaya River, Louisiana: A Preliminary Ecological Survey. DOER Technical Notes Collection ERDCTN-EWN-14-4. Vicksburg, MS: U.S. Army Engineer Research and Development Center. http://el.erdc.usace.army.mil/.

Berkowitz, W. 2013. Linking Wetland Functional Rapid Assessment Models with Quantitative Hydrological and Biogeochemical Measurements across a Restoration Chronosequence. Soil Science Society of America J ournal 77:14421451.

Blott, S. J., and K. Pye. 2001. GRADISTAT: A Grain Size Distribution and Statistics Package for the Analysis of Unconsolidated Sediments. Earth Surface Processes Landforms 26:1237- 1248. doi:10.1002/ esp.261.

Boesch, D. F., and R. E. Turner. 1984. Dependence of Fishery Species on Salt Marshes: The Role of Food and Refuge. Estuaries 7 (4): 460- 468.

Boesch, D. F., M. N. J osselyn, A. J. Mehta, J. T. Morris, W. K. Nuttle, C. A. Simenstad, and D. J . Swift. 1994. Scientific Assessment of Coastal Wetland Loss, Restoration and Management in Louisiana. J ournal of Coastal Research, Special Issue no. 20 .

Bourne, J . 2000. Louisiana's Vanishing Wetlands: Going, Going. . . . Science 289:18601863. 
Boustany, R. G. 2010. Estimating the Benefits of Freshwater Introduction into Coastal Wetland Ecosystems in Louisiana: Nutrient and Sediment Analyses. Ecological Restoration 28:160-174.

Bridges, T. S., J . Lillycrop, J . R. Wilson, J . T. Fredette, B. C. Suedel, C. J . Banks, and E. J . Russo. 2014. Engineering With Nature Promotes Triple-Win Outcomes. Terra et Aqua 135:17- 23.

Brinson, M. M. 1993. A Hydrogeomorphic Approach to Wetland Functional Assessment. Technical Report WRP-DE-4. Vicksburg, MS: U.S. Army Corps of Engineers Waterways Experiment Station.

Brinson, M. M., W. Kruczynski, L. C. Lee, W. L. Nutter, R. D. Smith, and D. F. Whigham. 1994. Developing an Approach for Assessing the Functions of Wetlands. In Global Wetlands: Old World and New, ed. W. J . Mitsch, 615-624. New York: Elsevier Science.

Broome, S. W., E. D. Seneca, and W. W. Woodhouse. 1986. Long-Term Growth and Development of Transplants of the Salt-Marsh Grass Spartina alterniflora. Estuaries 9:63- 74.

Burger, J . 1978. The Patterns and Mechanism of Nesting in Mixed-Species Heronries. In Wading Birds, ed. A. Sprunt, IV, J . C. Ogden, and S. Winkler, 45- 58. Research Report No 7. New York: National Audubon Society.

Cain, III, J .W., M. L. Morrison, and H. L., Bombay. 2003. Predator Activity and Nest Success of Willow Flycatchers and Yellow Warblers. J ournal of Wildlife Management 67:600-610.

Cammen, L. M. 1976. Abundance and Production of Macroinvertebrates from Natural and Artificially Established Salt Marshes in North Carolina. American Midland Naturalist 96:487-493.

Castellanos, D. L., and L. P. Rozas. 2001. Nekton Use of Submerged Aquatic Vegetation, Marsh, and Shallow Unvegetated Bottom in the Atchafalaya River Delta, a Louisiana Tidal Freshwater Ecosystem. Estuaries 24 (2): 184- 197.

Chapman, R. S., B. H. J ohnson, and S. R. Vemulakonda. 1996. User's Guide for the Sigma Stretched Version of CH3D-WES. USACE WES Technical Report HL-96-21. Vicksburg, MS: U.S. Army Corps of Engineers Waterways Experiment Station.

Chesney, E. J ., Baltz, D. M. and R. G. Thomas. 2000. Louisiana Estuarine and Coastal Fisheries and Habitats: Perspectives from a Fish's Eye View. Ecological Applications 10 (2): 350- 366.

Corbino, J . 2014. Estimate of Annual Dredging Budget for the Lower Atchafalaya River. Personal Communication. 20 J anuary. U.S. Army Corps of Engineers, New Orleans District.

Costanza, R., O. Pérez-Maqueo, M. L. Martinez, P. Sutton, S. J . Anderson, and K. Mulder. 2008. The Value of Coastal Wetlands for Hurricane Protection. AMBIO: A J ournal of the Human Environment 37:241- 248. 
Cowardin, L. M., V. Carter, F. C. Golet, and E. T. LaToe. 1979. Classification of Wetlands and Deepwater Habitats of the United States. Washington, DC: U.S. Department of the Interior, U.S. Fish and Wildlife Service.

Craft, C. 2000. Co-Development of Wetland Soils and Benthic Invertebrate Communities Following Salt Marsh Creation. Wetlands Ecology and Management 8 (2-3): 197- 207.

Craft, C., J . Reader, J . N. Sacco, and S. W. Broome. 1999. Twenty-Five Years of Ecosystem Development of Constructed Spartina alterniflora (Loisel) Marshes. Ecological Applications 9 (4): 1405- 1419.

Craft, C., P. Megonigal, S. Broome, J . Stevenson, R. Freese, J . Cornell, L. Zheng, and J . Sacco. 2003. The Pace of Ecosystem Development of Constructed Spartina alterniflora Marshes. Ecological Applications 13 (5): 1417- 1432.

Custer, T. W., and R. G. Osborn. 1978. Feeding Habitat Use by Colonially-Breeding Herons, Egrets and Ibises in North Carolina. Auk 95:733- 743.

Day, J r., J . W., D. F. Boesch, E. J . Clairain, G. P. Kemp, S. B. Laska, W. J . Mitsch, K. Orth, H. Mashriqui, D. J. Reed, L. Shabman, C. Simenstad, B. J . Streever, R. R. Twilley, C. C. Watson, J . T. Wells, and D. F. Whigham. 2007. Restoration of the Mississippi Delta: Lessons from Hurricanes Katrina and Rita. Science 315:16791684.

DeLaune, R. D., and S. R. Pezeshki. 2003. The Role of Soil Organic Carbon in Maintaining Surface Elevation in Rapidly Subsiding U.S. Gulf of Mexico Coastal Marshes. Water, Air, and Soil Pollution 3:167- 179.

Edwards, K. R., and C. E. Proffitt. 2003. Comparison of Wetland Structural Characteristics between Created and Natural Salt Marshes in Southwest Louisiana, USA. Wetlands 23 (2): 344- 356.

Engle, V. D. 2011. Estimating the Provision of Ecosystem Services by Gulf of Mexico Coastal Wetlands. Wetlands 31(1):179- 193.

Evans, N. T., and F. T. Short. 2005. Functional Trajectory Models for Assessment of Transplanted Eelgrass, Zostera marina L., in the Great Bay Estuary, New Hampshire. Estuaries 28 (6): 936- 947.

Ewel, K. C., C. Cressa, R. T. Kneib, P. S. Lake, L. A. Levin, M. A. Palmer, P. Snelgrove, and D. H. Wall. 2001. Managing Critical Transition Zones. Ecosystems 4 (5): 452460.

EWN (Engineering With Nature). 2016. Engineering With Nature. Vicksburg, MS: U.S. Engineer Research and Development Center. https://ewn.el.erdc.dren.mil/.

Faulkner, S. P., and M. E. Poach. 1996. Functional Comparison of Created and Natural Wetlands in the Atchafalaya Delta, Louisiana. Technical Report WRP-RE-16. Vicksburg, MS: U.S. Army Corps of Engineers Waterways Experiment Station.

Frederick, P. C., and J . C. Ogden. 1997. Philopatry and Nomadism: Contrasting LongTerm Movement Behavior and Population Dynamics of White Ibises and Wood Storks. Colonial Waterbirds 20:316-323. 
Gardiner, E. S., and J . M. Oliver. 2005. Restoration of Bottomland Hardwood Forests in Lower Mississippi Alluvial Valley, U.S.A. In Restoration of Boreal and Temperate Forests, ed. J . A. Stanturf and P. Madsen, 235- 251. Boca Raton, FL: CRC Press.

Gardner, L. M., and J. R. White. 2010. Denitrification Enzyme Activity as an Indicator of Nitrate Movement through a Diversion Wetland. Soil Science Society of America Journal 74:1037- 1047.

Gerhardt-Smith, J . M., and C. J . Banks. 2014. USACE Regional Sediment Management and Engineering with Nature 2013 Workshop Summary. ERDC TN-EWN-14-3. Vicksburg, MS: U.S. Army Engineer Research and Development Center.

Gibbs, J . P., and L. K. Kinkel. 1997. Determinants of the Size and Location of Great Blue Heron Colonies. Colonial Waterbird Society 20:1- 165.

Goolsby, D. A., W. A. Battaglin, B. T. Aulenbach, and R. P. Hooper. 1999. Flux and Sources of Nutrients in the Mississippi-Atchafalaya Basin: Topic 3 Report for the Integrated Assessment on Hypoxia in the Gulf of Mexico. Decision Analysis Series no. 17. Silver Spring, MD: NOAA Coastal Ocean Office.

Groffman, P. M., G. C. Hanson, E. Kiviat, and G. Stevens. 1996. Variation in Microbial Biomass and Activity in Four Different Wetland Types. Soil Science Society of America J ournal 60:622-629.

Hoover, J . P. 2006. Water depth Influences Nest Predation for a Wetland-Dependent Bird in Fragmented Bottomland Forests. Biological Conservation 127:37- 45.

Hurlbert, S. H. 1984. Pseudoreplication and the Design of Ecological Field Experiments. Ecological Monographs 54:187- 211.

J enny, H. 1980. The Soil Resource: Origin and Behavior. New York: Springer-Verlag.

J ohnson, W. B., C. E. Sasser, and J .G. Gosselink. 1985. Succession of Vegetation in an Evolving River Delta, Atchafalaya Bay, Louisiana. J ournal of Ecology 73 (3): 973-986

J ohnston, C. A. 1994. Cumulative Impacts to Wetlands. Wetlands 14 (1): 49- 55.

Kahn, L. 1998. Determination of Total Organic C in Sediment (Lloyd Kahn Method). Edison, NJ : U.S. Environmental Protection Agency, Environmental Services Division.

King, S. L., and B. D. Keeland. 1999. Evaluation of Reforestation in the Lower Mississippi River Alluvial Valley. Restoration Ecology 7:348- 359.

King, S. L., D. L. Twedt, and R. R. Wilson. 2006. The Role of the Wetland Reserve Program in Conservation Efforts in the Mississippi River Alluvial Valley. Wildlife Society Bulletin 34:914-920.

Klute, A. 1986. Methods of Soil Analysis: Part 1 Physical and Mineralogical Methods. 3rd ed. Madison, WI: Soil Science Society of America Press. 
Knutson, P. L. 1977. Planting Guidelines for Marsh Development and Bank Stabilization. Coastal Engineering Technical Aid No. 77-3. Fort Belvoir, VA: U.S. Army Corps of Engineers Coastal Engineering Research Center.

Konert, M., and J . E. F. Vandenberghe. 1997. Comparison of Laser Grain Size Analysis with Pipette and Sieve Analysis: A Solution for the Underestimation of the Clay Fraction. Sedimentology 44 (3): 523- 535.

Krebs, J . R. 1974. Colonial Nesting and Social Feeding as Strategies for Exploiting Food Resources in the Great Blue Heron (Ardea herodias). Behaviour 51:99- 134.

Kurz, R. C., R. W. Fenwick, and K. A. Davis. 1998. A Comparison of Fish Communities in Restored and Natural Salt Marshes in Tampa Bay, Florida. Tampa, FL: Southwest Florida Water Management District.

Landin, M. C., J. W. Webb, and P. L. Knudson. 1989. Long-Term Monitoring of Eleven Corps of Engineers Habitat Development Field Sites Built of Dredged Material, 1974- 1987. Waterways Experiment Station Technical Report D-89-1. Vicksburg, MS: U.S. Army Corps of Engineers Waterways Experiment Station.

Lindau, C. W., and L. R. Hossner. 1981. Substrate Characterization of an Experimental Marsh and Three Natural Marshes. Soil Science Society of America J ournal 45 (6): 1171- 1176.

Lindau, C. W., R. D. Delaune, A. E. Scaroni, and J . A. Nyman. 2008. Denitrification in Cypress Swamp within the Atchafalaya River Basin, Louisiana. Chemosphere 70 (5): 886- 894.

Llewellyn, D. W.,G. P. Shaffer, N. J . Craig, L. Creasman, D. Pashley, M. Swan, and C. Brown. 1996. A Decision-Support System for Prioritizing Restoration Sites on the Mississippi River Alluvial Plain. Conservation Biology 10 (5): 1446- 1455.

Loizeau, J . L., D. Arbouille, S. Santiago, and J . P. Vernet. 1994. Evaluation of a Wide Range Laser Diffraction Grain Size Analyser for Use with Sediments. Sedimentology 41 (2): 353- 361.

Mallach, T. J ., and P. L. Leberg. 1999. Use of Dredged Material Substrates by Nesting Terns and Black Skimmers. The J ournal of Wildlife Management, 63 (1): 137146.

Matthews, S. L., J . S. Boates, and S. J . Walde. 1992. Shorebird Predation May Cause Discrete Generations in an Amphipod Prey. Ecography 15:393- 400.

McCrimmon, J r., D. A. 1978. Nest Site Characteristics among Five Species of Herons on the North Carolina Coast. Auk 95 (2): 267- 280.

Mitsch, W. J ., and J. W. Day Jr. 2006. Restoration of Wetlands in the Mississippi- OhioMissouri (MOM) River Basin: Experience and Needed Research. Ecological Engineering 26 (1): 55- 69. 
Mitsch, W. J., J. W. Day, J . W. Gilliam, P. M. Groffman, D. L. Hey, G. W. Randall, N. Wang. 2001. Reducing Nitrogen Loading to the Gulf of Mexico from the Mississippi River Basin: Strategies to Counter a Persistent Ecological Problem Ecotechnology-The Use of Natural Ecosystems to Solve Environmental Problems-Should Be a Part of Efforts to Shrink the Zone of Hypoxia in the Gulf of Mexico. BioScience 51 (5): 373- 388.

Mitsch, W. J., J. W. Day, L. Zhang, and R. R. Lane, R. R. 2005. Nitrate-Nitrogen Retention in Wetlands in the Mississippi River Basin. Ecological Engineering 24 (4): 267- 278.

Nature Conservancy, The. 1992. Restoration of the Mississippi River Alluvial Plain as a Functional Ecosystem. Hammond, LA: Southeastern Louisiana University.

NOAA (National Oceanic and Atmospheric Administration). 2013. Harmonic Constituents for 8764227, LAWMA, Amerada Pass LA. Tides and Currents. Washington, DC: National Oceanic and Atmospheric Administration. http://tidesandcurrents.noaa.gov/harcon.html?id=8764227.

Novitski, R. P., R. D. Smith, and J . D. Fretwell. 1996. Wetland Functions, Values, and Assessment. In National Water Summary on Wetland Resources, ed. J. D. Fretwell, J . S. Williams, and P. J . Redman, 79- 86. USGS Water-Supply Paper 2425. Washington, DC: U.S. Department of the Interior, U.S. Geological Survey.

NRCS (Natural Resources Conservation Service). 2010. Field Indicators of Hydric Soils in the United States: A Guide for Identifying and Delineating Hydric Soils, Version 7.0. Washington, DC: United States Department of Agriculture, Natural Resources Conservation Service.

— 2013. The PLANTS Database. http://plants.usda.gov (accessed 31J anuary 2013). Washington, DC: United States Department of Agriculture, Natural Resources Conservation Service.

Palermo, M., P. Schroeder, T. Estes, N. Francingues, K. Gustavson, T. Bridges, and S. Ells. 2009. USACE Technical Guidelines for Environmental Dredging of Contaminated Sediments. In Proceedings of the 29th Western Dredging Association Technical Conference 2009 Held with the 40th Texas A\&M Dredging Seminar, 14-17J une, Tempe, AZ, ed. R. E. Randall, 300-310. Vancouver, WA: Western Dredging Association.

Palermo, M. R., and N. R. Francingues. 1992. Evaluating Environmental Effects of Dredged Material Management Alternatives: A Technical Framework. EPA842B-92-008. Washington, DC: U.S. Environmental Protection Agency and U.S. Army Corps of Engineers.

Partners in Flight 2006. Species Assessment Database. http://www.rmbo.org/pif/scores/scores.html (accessed 1 September 2014).

Parton, W.J ., Schimel, D.S., Cole, C.V., Ojima, D.S. 1987. Analysis of Factors Controlling Soil Organic Matter Levels in Great Plains Grasslands. Soil Science Society of America J ournal 51:1173- 1179.

Piazza, B. P., and V. L. Wright. 2004. Within-Season Nest Persistence in Large Wading Bird Rookeries. Waterbirds 27 (3): 362- 367. 
Picman, J ., M. Milks, and M. Leptich. 1993. Patterns of Predation on Passerine Nests in Marshes: Effects of Water Depth and Distance from Edge. Auk 110:89-94.

Pribyl, D. W. 2010. A Critical Review of the Conventional SOC to SOM Conversion Factor. Geoderma 156:75- 83.

Rabalais, N. N. 1990. Biological Communities of the South Texas Continental Shelf. American Zoologist 30 (1): 77- 87.

Rabalais, N. N., W. J. Wiseman, and R. E. Turner. 1994. Comparison of Continuous Records of Near-Bottom Dissolved Oxygen from the Hypoxia Zone along the Louisiana Coast. Estuaries 17 (4): 850- 861.

Rabenhorst, M. C. 1995. Carbon Storage in Tidal Marsh Soils. In Soils and Global Change, ed. R. Lal, J . Kimble, E. Levine, and B. A. Stewart, 93- 104. CRC, Boca Raton.

Ray, G. L. 2000. Infaunal Assemblages on Constructed Intertidal Mudflats at J onesport, Maine (USA). Marine Pollution Bulletin 40 (12): 1186- 1200.

Reddy, K. R., and R. D. DeLaune. 2008. Biogeochemistry of Wetlands. Boca Raton, FL: CRC press.

Roy, E.D., and J . R. White. 2012. Nitrate Flux into the Sediments of a Shallow Oligohaline Estuary during Large Flood Pulses of Mississippi River Water. J ournal of Environmental Quality 41: 1549- 1556.

Roy, E. D., J . R. White, E. A. Smith, S. Bargu, and C. Li. 2013. Estuarine Ecosystem Response to Three Large-Scale Mississippi River Flood Diversion Events. Science of the Total Environment 458:374- 387.

Schreiber, R. A., and E. A. Schreiber. 1978. Colonial Bird Use and Plant Succession on Dredged Material Islands in Florida. Technical Report D-78-14. Vicksburg, MS: U.S. Army Corps of Engineers Waterways Experiment Station.

Shafer, D. J ., and W. J . Streever. 2000. A Comparison of 28 Natural and Dredged Material Salt Marshes in Texas with an Emphasis on Geomorphological Variables. Wetlands Ecology and Management 8 (5): 353- 366.

Shaffer, G. P., C. E. Sasser, J . G. Gosselink, and M. Rejmanek. 1992. Vegetation Dynamics in the Emerging Atchafalaya Delta, Louisiana, USA. J ournal of Ecology 80:677687.

Smith, R. D., and C. V. Klimas. 2002. A Regional Guidebook for Applying the Hydrogeomorphic Approach to Assessing Wetland Functions of Selected Regional Wetland Subclasses, Yazoo Basin, Lower Mississippi River Alluvial Valley. ERDC/ EL TR-02-4. Vicksburg, MS: U.S. Army Engineer Research and Development Center.

Smith, R. D., C. V. Noble, and J . F. Berkowitz. 2013. Hydrogeomorphic (HGM) Approach to Assessing Wetland Functions: Guidelines for Developing Guidebooks (Version 2). ERDC/ EL TR-13-11. Vicksburg, MS: U.S. Army Engineer Research and Development Center. 
Sparks, D. L. 1996. Methods of Soil Analysis. Part 3: Chemical Methods. 3rd ed. Madison, WI: Soil Science Society of America and American Society of Agronomy.

Stedman, S. M., and T. E. Dahl. 2008. Status and Trends of Wetlands in the Coastal Watersheds of the Eastern United States, 1998 to 2004. Silver Spring, MD: National Oceanic and Atmospheric Administration, National Marine Fisheries Service.

Stern, M. K., J . W. Day, and K. G. Teague. 1991. Nutrient Transport in a RiverineInfluenced, Tidal Freshwater Bayou in Louisiana. Estuaries 14 (4): 382- 394.

Streever, W. J . 2000. Spartina alterniflora Marshes on Dredged Material: A Critical Review of the Ongoing Debate over Success. Wetlands Ecology and Management 8 (5): 295- 316.

Strong, A. M., G. T. Bancroft, and S. D. J ewell. 1997. Hydrological Constraints on Tricolored Heron and Snowy Egret Resource Use. Condor 99:894- 905.

Templet, P. H., and K. J . Meyer-Arendt. 1998. Louisiana Wetland Loss: A Regional Water Management Approach to the Problem. Environmental Management 12 (2): 181- 192.

Theriot, J . M., J . L. Conkle, S. Reza Pezeshki, R. D. DeLaune, and J . R. White. 2013. Will Hydrologic Restoration of Mississippi River Riparian Wetlands Improve Their Critical Biogeochemical Functions? Ecological Engineering 60:192- 198.

Turner, R. E. 1997. Wetland Loss in the Northern Gulf of Mexico: Multiple Working Hypotheses. Estuaries 20:1- 13.

Twedt, D. J., and S. G. Somershoe. 2009. Bird Response to Prescribed Silvicultural Treatments in Bottomland Hardwood Forests. J ournal of Wildlife Management 73:1140-1150.

University of New Orleans. 2002. Beneficial Use of Dredged Material Monitoring Program Results of Monitoring the Beneficial Use of Dredged Material at the Atchafalaya River and Bayous Chene, Boeuf, and Black, Louisiana-Lower Atchafalaya River-Horseshoe Base Year 1985 through J anuary 2001. University of New Orleans.

USACE (U.S. Army Corps of Engineers). 1983. Engineering and Design, Dredging and Dredged Material Disposal. Engineering Manual 1110-2-5025. Washington, DC: U.S. Army Corps of Engineers.

_ 1986. Beneficial Uses of Dredged Material. Engineer Manual EM 1110-2-5026. Washington, DC: U.S. Army Corps of Engineers, Office of the Chief of Engineers.

_ 2004. Louisiana Coastal Area (LCA), Louisiana: Ecosystem Restoration Study. New Orleans, LA: U.S. Army Corps of Engineers.

_ 2010. Regional Supplement to the Corps of Engineers Wetland Delineation Manual: Atlantic and Gulf Coastal Plain Region (Version 2.0), ed. J . S. Wakeley, R. W. Lichvar, and C. V. Noble. ERDC/ EL TR-10-20. Vicksburg, MS: U.S. Army Engineer Research and Development Center. 
USEPA (U.S. Environmental Protection Agency). 1993. Phosphorus, All Forms (Colorimetric, Automated, Ascorbic Acid). USEPA Method 365.1. Methods for the Determination of Inorganic Substances in Environmental Samples. Washington DC: U.S. Environmental Protection Agency.

_ 2002. Methods for Evaluating Wetland Condition: Introduction to Wetland Biological Assessment. EPA-822-R-02-014. Washington, DC: U.S. Environmental Protection Agency, Office of Water.

USGS (U.S. Geological Survey). 2016. USGS Water Data for the Nation. Reston, VA: U.S. Geological Survey. http://waterdata.usgs.gov/nwis.

van Heerden, I. L., and H. H. Roberts. 1980. The Atchafalaya Delta: Rapid Progradation Along a Traditionally Retreating Coast (South Central Louisiana). Zietschrift fur Geomorphologie 34:188- 201.

Vance, E. D., P. C. Brookes, and D. S. J enkinson. 1987. An Extraction Method for Measuring Soil Microbial Biomass C. Soil Biology and Biochemistry 19:703- 707.

VanZomeren, C. M., J . R. White, and R. D. DeLaune. 2013. Ammonification and Denitrification Rates in Coastal Louisiana Bayou Sediment and Marsh Soil: Implications for Mississippi River Diversion Management. Ecological Engineering 54:77-81.

Vepraskas, M. J., C. B. Craft, and J . L. Richardson. 2001. Wetland Soils: Genesis, Hydrology, Landscapes, and Classification. Boca Raton, FL: CRC Press.

Wamsley, T. V., M. A. Cialone, J . M. Smith, J . H. Atkinson, and J . D. Rosati. 2010. The Potential of Wetlands in Reducing Storm Surge. Ocean Engineering 37 (1): 5968.

Wang, F. C., 1984. The Dynamics of a River-Bay-Delta System. J ournal of Geophysical Research 89:8054- 8060.

Webb, J . W. 1982. Salt Marshes of the Western Gulf of Mexico. In Creation and Restoration of Coastal Plant Communities, ed. R. R. Lewis, 89- 110. Boca Raton, FL: CRC Press.

Webb, J . W., and C. J . Newling. 1985. Comparison of Natural and Man-Made Salt Marshes in Galveston Bay Complex, Texas. Wetlands 4:75- 86.

Wells, B., D. H. Steele, and A. V. Tyler. 1973. Intertidal Feeding of Winter Flounders (Pseudopleuronectes americanus) in the Bay of Fundy. J ournal of the Fisheries Board of Canada, 30(9), pp.1374-1378.

White, J . R., and K. R. Reddy. 2001. Influence of Selected Inorganic Electron Acceptors on Organic Nitrogen Mineralization in Everglades Soils. Soil Science Society of America J ournal 65:941-948.

Woodhouse, W. W., E. D. Seneca, and S. W. Broome. 1974. Propagation of Spartina alterniflora for Substrate Stabilization and Saltmarsh Development. Technical Memorandum 46. Fort Belvoir, VA: U.S. Army Coastal Engineering Research Center. 
Yozzo, D. J., P. Wilber, and R. J . Will. 2004. Beneficial Use of Dredged Material for Habitat Creation, Enhancement, and Restoration in New York- NewJ ersey Harbor. J ournal of Environmental Management 73 (1): 39- 52.

Yu, K., R. D. DeLaune, and P. Boeckx. 2006. Direct Measurement of Denitrification Activity in a Gulf Coast Freshwater Marsh Receiving Diverted Mississippi River Water. Chemosphere 65 (11): 2449- 2455.

Zedler, J . B. 2000. Progress in Wetland Restoration Ecology. Trends in Ecology \& Evolution 15(10): 402- 407. 


\section{Appendix A: List of Plant Species Observed at Horseshoe Bend Island, Middle Island, and Island E}

\begin{tabular}{|c|c|c|c|c|c|}
\hline Scientific Name & Common Name & Family & $\begin{array}{l}\text { Middle } \\
\text { Island }\end{array}$ & Island E & $\begin{array}{l}\text { Horseshoe } \\
\text { Island }\end{array}$ \\
\hline Acer negundo L. & boxelder & Aceraceae & $\mathrm{X}$ & & \\
\hline Acer rubrum L. & red maple & Aceraceae & $x$ & $x$ & \\
\hline $\begin{array}{l}\text { Alternanthera philoxeroides } \\
\text { (Mart.) Griseb. }\end{array}$ & alligatorweed & Amaranthaceae & $x$ & $\mathrm{x}$ & $x$ \\
\hline $\begin{array}{l}\text { Amaranthus australis (Gray) } \\
\text { Sauer }\end{array}$ & southern amaranth & Amaranthaceae & & & $\mathrm{X}$ \\
\hline Amaranthus spp. L. & pigweed & Amaranthaceae & $x$ & $x$ & $x$ \\
\hline Ammannia spp. & redstem & Lythraceae & & & $x$ \\
\hline Amorpha fruiticosa $\mathrm{L}$. & false indigo bush & Fabaceae & $x$ & $x$ & $x$ \\
\hline $\begin{array}{l}\text { Ampelopsis arborea (L.) } \\
\text { Koehne }\end{array}$ & peppervine & Vitaceae & $x$ & $x$ & $x$ \\
\hline Ampelopsis cordata Michx. & heartleaf peppervine & Vitaceae & $x$ & & $\mathrm{X}$ \\
\hline Apios americana Medik. & groundnut & Fabaceae & $x$ & & \\
\hline Aster spp. & aster & Asteraceae & $x$ & & \\
\hline Baccharis halimifolia L. & eastern baccharis & Asteraceae & & $x$ & $\mathrm{X}$ \\
\hline Bacopa monnierri (L.) Pennell & herb of grace & Scrophulariaceae & $x$ & $x$ & \\
\hline $\begin{array}{l}\text { Bidens laevis (L.) Britton, } \\
\text { Sterns \& Poggenb. }\end{array}$ & smooth beggartick & Asteraceae & & & $x$ \\
\hline Boehmeria cylindrica (L.) Sw. & $\begin{array}{l}\text { smallspike false } \\
\text { nettle }\end{array}$ & Urticaceae & $\mathrm{X}$ & $x$ & $\mathrm{X}$ \\
\hline Borrichia Adans. & seaside tansy & Asteraceae & $x$ & & \\
\hline $\begin{array}{l}\text { Brunnichia ovata (Walter) } \\
\text { Shinners }\end{array}$ & $\begin{array}{l}\text { American buckwheat } \\
\text { vine }\end{array}$ & Polygonaceae & $\mathrm{X}$ & & \\
\hline $\begin{array}{l}\text { Campsis radicans (L.) Seem. Ex } \\
\text { Bureau }\end{array}$ & trumpet creeper & Bignoniaceae & $x$ & & \\
\hline $\begin{array}{l}\text { Carex bromoidesSchkuhr ex } \\
\text { Willd. }\end{array}$ & broom-like sedge & Cyperaceae & $\mathrm{x}$ & & \\
\hline Carex spp. & unknown sedge & Cyperaceae & & $x$ & \\
\hline Carya spp. & hickory & Juglandaceae & $x$ & & \\
\hline Celtis laevigata Willd. & sugarberry & Ulmaceae & $x$ & & \\
\hline Cephalanthus occidentalis L. & common buttonbush & Rubiaceae & & $\mathrm{X}$ & $x$ \\
\hline Ceratophyllum demersum L. & coon's tail & Certophyllaceae & & $x$ & \\
\hline Cicuta maculata L. & $\begin{array}{l}\text { spotted water } \\
\text { hemlock }\end{array}$ & Apiaceae & & $x$ & $\mathrm{X}$ \\
\hline Cirsium horridulum Michx. & yellow thistle & Asteraceae & & $x$ & $x$ \\
\hline Colocasia esculenta (L.) Schott & coco-yam & Araceae & $x$ & $x$ & $x$ \\
\hline
\end{tabular}




\begin{tabular}{|c|c|c|c|c|c|}
\hline Scientific Name & Common Name & Family & $\begin{array}{l}\text { Middle } \\
\text { Island }\end{array}$ & Island E & $\begin{array}{l}\text { Horseshoe } \\
\text { Island }\end{array}$ \\
\hline Commelina virginica L. & Virginia dayflower & Commelinaceae & $\mathrm{X}$ & $x$ & \\
\hline Cornus foemina Mill. & stiff dogwood & Cornaceae & $x$ & $x$ & \\
\hline Crinum americanum L. & seven sisters & Liliaceae & & $x$ & $x$ \\
\hline Cuscuta spp. L. & dodder & Convolvulaceae & $x$ & & \\
\hline Cyperus esculentus L. & yellow nutsedge & Cyperaceae & & & $x$ \\
\hline Cyperus pseudovegetus Steud. & marsh flatsedge & Cyperaceae & & & $x$ \\
\hline Cyperus spp. & flatsedge & Cyperaceae & & $x$ & $x$ \\
\hline $\begin{array}{l}\text { Dichanthelium clandestinum } \\
\text { (L.) Gould }\end{array}$ & deertongue & Poaceae & $x$ & $x$ & \\
\hline Diospyros virginiana L. & persimmon & Ebenaceae & $x$ & & \\
\hline $\begin{array}{l}\text { Echinochloa walteri (Pursh) A. } \\
\text { Heller }\end{array}$ & coast cockspur grass & Poaceae & & & $x$ \\
\hline $\begin{array}{l}\text { Eichhornia crassipes (Mart.) } \\
\text { Solms }\end{array}$ & $\begin{array}{l}\text { common water } \\
\text { hyacinth }\end{array}$ & Pontederiaceae & $x$ & $x$ & $x$ \\
\hline Eleocharis spp. R. Br. & spikerush & Cyperaceae & & & $x$ \\
\hline Equisetum hyemale L. & $\begin{array}{l}\text { scouringrush } \\
\text { horsetail }\end{array}$ & Equisetaceae & $x$ & & \\
\hline $\begin{array}{l}\text { Eupatorium capillifolium (Lam.) } \\
\text { Small }\end{array}$ & dogfennel & Asteraceae & & $x$ & $x$ \\
\hline Euthamia spp. Nutt. Ex Cass. & goldentop & Asteraceae & & & $x$ \\
\hline $\begin{array}{l}\text { Forestiera acuminata (Michx.) } \\
\text { Poir. }\end{array}$ & eastern swampprivet & Oleaceae & $x$ & & \\
\hline $\begin{array}{l}\text { Fraxinus pennsylvanica } \\
\text { Marshall }\end{array}$ & green ash & Oleaceae & $x$ & $x$ & \\
\hline Galium spp. & bedstraw & Rubiaceae & & $x$ & $x$ \\
\hline Gleditsia aquatica Marsh. & water locust & Fabaceae & & $x$ & $x$ \\
\hline Gleditsia triacanthos L. & honeylocust & Fabaceae & & $x$ & \\
\hline Heliotropium indicum L. & Indian heliotrope & Boraginaceae & & & $x$ \\
\hline $\begin{array}{l}\text { Heteranthera dubia (Jacq.) } \\
\text { MacMill. }\end{array}$ & \begin{tabular}{|l|} 
grassleaf \\
mudplantain
\end{tabular} & Pontederiaceae & & $x$ & \\
\hline Hibiscus laevis All. & $\begin{array}{l}\text { halberdleaf } \\
\text { rosemallow }\end{array}$ & Malvaceae & $x$ & $x$ & \\
\hline Hibiscus lasiocarpos Cav. & rosemallow & Malvaceae & & & $x$ \\
\hline Hydrilla verticillata (L. f.) Royle & waterthyme & Hydrocharitaceae & & $x$ & $x$ \\
\hline Hydrocotyle ranunculoides L. f. & $\begin{array}{l}\text { floating } \\
\text { marshpennywort }\end{array}$ & Apiaceae & & $\mathrm{x}$ & \\
\hline Hydrocotyle verticillata Thunb. & $\begin{array}{l}\text { whorled } \\
\text { marshpennywort }\end{array}$ & Apiaceae & & $x$ & $x$ \\
\hline $\begin{array}{l}\text { Hymenocallis liriosme (Raf.) } \\
\text { Shinners }\end{array}$ & spring spiderlily & Lilieaceae & $x$ & $x$ & \\
\hline Hypericum mutilum L. & dwarf St. Johnswort & Clusiaceae & & & $x$ \\
\hline Ilex decidua Walter & possumhaw & Aquifoliaceae & $x$ & & \\
\hline
\end{tabular}




\begin{tabular}{|c|c|c|c|c|c|}
\hline Scientific Name & Common Name & Family & $\begin{array}{l}\text { Middle } \\
\text { Island }\end{array}$ & Island E & $\begin{array}{l}\text { Horseshoe } \\
\text { Island }\end{array}$ \\
\hline Ipomea spp. & morning-glory & Convolvulaceae & $\mathrm{X}$ & $\mathrm{X}$ & $\mathrm{X}$ \\
\hline Iris spp. (L.) & iris & Iridaceae & & $x$ & \\
\hline Iris virginica L. & Virginia iris & Iridaceae & & & $x$ \\
\hline Iva annua L. & annual marsh elder & Asteraceae & & $x$ & $x$ \\
\hline Juncus effusus L. & common rush & Juncaceae & & $x$ & \\
\hline $\begin{array}{l}\text { Justicia lanceolata(Chapm.) } \\
\text { Small }\end{array}$ & $\begin{array}{l}\text { looseflower water- } \\
\text { willow }\end{array}$ & Acanthaceae & & $x$ & \\
\hline $\begin{array}{l}\text { Kosteletzkya virginica (L.) C. } \\
\text { Presl ex A. Gray }\end{array}$ & $\begin{array}{l}\text { Virginia saltmarsh } \\
\text { mallow }\end{array}$ & Malvaceae & & & $x$ \\
\hline Lactuca spp. & lettuce & Asteraceae & & & $x$ \\
\hline Leersia oryzoides (L.) Sw. & rice cutgrass & Poaceae & & $x$ & $x$ \\
\hline Lemna minor L. & common duckweed & Lemnaceae & & $x$ & $x$ \\
\hline Ludwigia alterniflora L. & seedbox & Onagraceae & & $x$ & \\
\hline Ludwigia decurrens Walter & $\begin{array}{l}\text { wingleaf primrose- } \\
\text { willow }\end{array}$ & Onagraceae & $x$ & $x$ & \\
\hline Ludwigia glandulosa Walter & $\begin{array}{l}\text { cylindricfruit } \\
\text { primrose-willow }\end{array}$ & Onagraceae & & $x$ & \\
\hline $\begin{array}{l}\text { Ludwigia peploides(Kunth) P.H. } \\
\text { Raven }\end{array}$ & $\begin{array}{l}\text { floating primrose- } \\
\text { willow }\end{array}$ & Onagraceae & & $x$ & \\
\hline Ludwigia spp. & primrose-willow & Onagraceae & & $x$ & $x$ \\
\hline $\begin{array}{l}\text { Lygodium japonicum (Thunb.) } \\
\text { Sw. }\end{array}$ & $\begin{array}{l}\text { Japanese climbing } \\
\text { fern }\end{array}$ & Lygodiaceae & $x$ & & $x$ \\
\hline Lythrum alatum L. & winged lythrum & Lythraceae & & & $x$ \\
\hline Lythrum lineare L. & wand lythrum & Lythraceae & & $x$ & $x$ \\
\hline Menisperumum canadense L. & common moonseed & Menispermaceae & $x$ & & \\
\hline Mikania scandens (L.) Willd. & climbing hempvine & Asteraceae & $x$ & $x$ & $x$ \\
\hline Morella cerifera (L.) Small & way myrtle & Myricaceae & $x$ & $x$ & $x$ \\
\hline Morus rubra L. & red mulberry & Moraceae & $x$ & & $x$ \\
\hline Nelumbo lutea Willd. & American lotus & Nelumbonaceae & & $x$ & $x$ \\
\hline $\begin{array}{l}\text { Nymphaea odorata Aiton ssp. } \\
\text { odorata }\end{array}$ & $\begin{array}{l}\text { American white } \\
\text { waterlily }\end{array}$ & Nymphaeaceae & & & $x$ \\
\hline Nyssa sylvatica Marshall & blackgum & Cornaceae & $x$ & & \\
\hline $\begin{array}{l}\text { Packera glabella (Poir.) C. } \\
\text { Jeffrey }\end{array}$ & butterweed & Asteraceae & & $x$ & \\
\hline Panicum repens $\mathrm{L}$. & torpedo grass & Poaceae & $x$ & $x$ & $x$ \\
\hline $\begin{array}{l}\text { Parthenocissus quinquefolia } \\
\text { (L.) Planch. }\end{array}$ & Virginia creeper & Vitaceae & $x$ & $x$ & \\
\hline Paspalum L. & crowngrass & Poaceae & & & $x$ \\
\hline $\begin{array}{l}\text { Phanopyrum gymnocarpon } \\
\text { (Elliott) Nash }\end{array}$ & savannah-panicgrass & Poaceae & $x$ & & \\
\hline $\begin{array}{l}\text { Phragmites australis (Cav.) Trin. } \\
\text { Ex Steud. }\end{array}$ & common reed & Poaceae & & & $x$ \\
\hline
\end{tabular}




\begin{tabular}{|c|c|c|c|c|c|}
\hline Scientific Name & Common Name & Family & $\begin{array}{l}\text { Middle } \\
\text { Island }\end{array}$ & Island E & $\begin{array}{l}\text { Horseshoe } \\
\text { Island }\end{array}$ \\
\hline $\begin{array}{l}\text { Phyla lanceolata (Michx.) } \\
\text { Greene }\end{array}$ & lanceleaf fogfruit & Verbenaceae & & & $x$ \\
\hline Phyla nodiflora (L.) Greene & turkey tangle fogfruit & Verbenaceae & $x$ & $x$ & $x$ \\
\hline Phytolacca americana L. & American pokeweed & Phytolaccaceae & & $x$ & \\
\hline Pistia stratiotes L. & water lettuce & Araceae & & $x$ & $x$ \\
\hline Platanus occidentalis L. & American sycamore & Platanaceae & $x$ & & $x$ \\
\hline Pluchea rosea Godfrey & rosy camphorweed & Asteraceae & & & $x$ \\
\hline $\begin{array}{l}\text { Polygonum hydropiperoides } \\
\text { Michx. }\end{array}$ & swamp smartweed & Polygonaceae & & $x$ & $x$ \\
\hline Polygonum L. & knotweed & Polygonaceae & $\mathrm{X}$ & $\mathrm{x}$ & \\
\hline Polygonum punctatum Ell. & dotted smartweed & Polygonaceae & & & $x$ \\
\hline Pontederia cordata L. & pickerelweed & Pontederiaceae & & & $x$ \\
\hline $\begin{array}{l}\text { Populus deltoides W. Bart. ex } \\
\text { Marshall }\end{array}$ & eastern cottonwood & Salicaceae & $\mathrm{x}$ & $\mathrm{x}$ & \\
\hline Populus heterophylla L. & swamp cottonwood & Salicaceae & $x$ & $x$ & \\
\hline Quercus nigra L. & water oak & Fagaceae & $x$ & & \\
\hline $\begin{array}{l}\text { Rhynchospora colorata(L.) H. } \\
\text { Pfeiffer }\end{array}$ & starrush whitetop & Cyperaceae & $x$ & & \\
\hline Rubus argutus Link & sawtooth blackberry & Rosaceae & $x$ & $x$ & $x$ \\
\hline Rubus spp. L. & blackberry & Rosaceae & $x$ & $x$ & \\
\hline Ruppia maritima L. & widgeongrass & Ruppiaceae & & $x$ & $x$ \\
\hline Sagittaria latifolia Willd. & broadleaf arrowhead & Alismataceae & & $\mathrm{X}$ & $x$ \\
\hline Salix nigra Marshall & black willow & Salicaceae & $x$ & $\mathrm{X}$ & $x$ \\
\hline Salvinia minima Baker & water spangles & Salviniaceae & & $\mathrm{X}$ & $x$ \\
\hline $\begin{array}{l}\text { Sambucus nigra L. ssp. } \\
\text { canadensis }\end{array}$ & common elderberry & Caprifoliaceae & $x$ & $x$ & $x$ \\
\hline $\begin{array}{l}\text { Samolus valerandi L. ssp. } \\
\text { parviflorus (Raf.) Hulten }\end{array}$ & seaside brookweed & Primulaceae & & & $\mathrm{x}$ \\
\hline Saururus cernuus L. & lizard's tail & Saururaceae & $x$ & $x$ & $x$ \\
\hline $\begin{array}{l}\text { Schoenoplectus americanus } \\
\text { (Pers.) Volkart ex Schinz \& R. } \\
\text { Keller }\end{array}$ & chairmaker's bulrush & Cyperaceae & & & $\mathrm{x}$ \\
\hline $\begin{array}{l}\text { Schoenoplectus californicus } \\
\text { (C.A. Mey.) Palla }\end{array}$ & California bulrush & Cyperaceae & & & $x$ \\
\hline $\begin{array}{l}\text { Sesbania drummondii (Rydb.) } \\
\text { Cory }\end{array}$ & poisonbean & Fabaceae & & $x$ & $x$ \\
\hline $\begin{array}{l}\text { Sesbania herbacea (Mill.) } \\
\text { McVaugh }\end{array}$ & bigpod sesbania & Fabaceae & & & $x$ \\
\hline Sicyos angulatus L. & $\begin{array}{l}\text { oneseed bur } \\
\text { cucumber }\end{array}$ & Cucurbitaceae & & $\mathrm{x}$ & $\mathrm{x}$ \\
\hline Smilax auriculata Walter & earleaf greenbriar & Smilacaceae & $x$ & & \\
\hline Solanum americanum Mill. & $\begin{array}{l}\text { American black } \\
\text { nightshade }\end{array}$ & Solanaceae & & & $x$ \\
\hline
\end{tabular}




\begin{tabular}{|c|c|c|c|c|c|}
\hline Scientific Name & Common Name & Family & $\begin{array}{l}\text { Middle } \\
\text { Island }\end{array}$ & Island E & $\begin{array}{l}\text { Horseshoe } \\
\text { Island }\end{array}$ \\
\hline Solidago altissima L. & Canada goldenrod & Asteraceae & & & $X$ \\
\hline Solidago sempervirens L. & seaside goldenrod & Asteraceae & & & $X$ \\
\hline Sphenoclea zeylanica Gaertn. & chickenspike & Sphenocleaceae & & & $X$ \\
\hline Taxodium ascendens Brongn. & pondcypress & Cupressaceae & $X$ & $X$ & \\
\hline Taxodium distichum (L.) Rich. & bald cypress & Cupressaceae & $X$ & $X$ & $X$ \\
\hline $\begin{array}{l}\text { Thelypteris kunthii (Desv.) } \\
\text { Morton }\end{array}$ & Kunth's maiden fern & Thelypteridaceae & $x$ & $x$ & $x$ \\
\hline $\begin{array}{l}\text { Toxicodendron radicans (L.) } \\
\text { Kuntze }\end{array}$ & eastern poisonivy & Anacardiaceae & $x$ & $\mathrm{X}$ & \\
\hline Tradescantia spp. L. & spiderwort & Commelinaceae & & $X$ & \\
\hline Triadica sebifera (L.) Small & Chinese tallowtree & Euphorbiaceae & $x$ & $x$ & $x$ \\
\hline Typha latifolia L. & broadleaf cattail & Typhaceae & & $x$ & $x$ \\
\hline Ulmus americana L. & American elm & Ulmaceae & $x$ & & \\
\hline Ulmus rubra Muhl. & slippery elm & Ulmaceae & $x$ & & \\
\hline Valerianella radiata (L.) Dufr. & beaked cornsalad & Valerianaceae & & $X$ & \\
\hline Vallisneria americana Michx. & American eelgrass & Hydrocharitaceae & & $X$ & \\
\hline Vigna luteola (Jacq.) Benth. & hairypod cowpea & Fabaceae & & & $x$ \\
\hline Vigna unguiculata (L.) Walp. & cowpea & Fabaceae & & $\mathrm{X}$ & $x$ \\
\hline Wisteria spp. Nutt. & wisteria & Fabaceae & $x$ & & \\
\hline Woodwardia virginica (L.) Sm. & Virginia chainfern & Blechnaceae & & $x$ & \\
\hline Xanthium strumarium L. & rough cocklebur & Asteraceae & & & $X$ \\
\hline
\end{tabular}




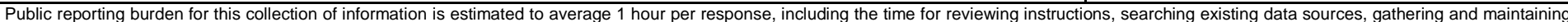

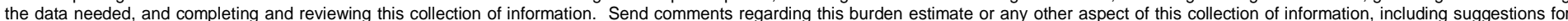

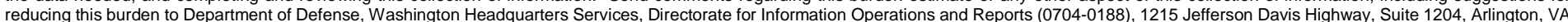

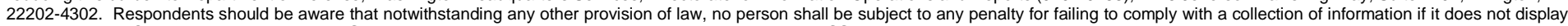
a currently valid OMB control number. PLEASE DO NOT RETURN YOUR FORM TO THE ABOVE ADDRESS.
1. REPORT DATE (DD-MM-YYYY)
2. REPORT TYPE
June 2017
Technical Report/Final

\section{TITLE AND SUBTITLE}

A Multifactor Ecosystem Assessment of Wetlands Created Using a Novel Dredged Material Placement Technique in the Atchafalaya River, Louisiana: An Engineering With Nature Demonstration Project

\section{DATES COVERED (From - To)}

5a. CONTRACT NUMBER

5b. GRANT NUMBER

5c. PROGRAM ELEMENT NUMBER

6. AUTHOR(S)

5d. PROJECT NUMBER

Jacob F. Berkowitz, Sung-Chan Kim, Nathan R. Beane, Darrell E. Evans, Elizabeth Summers, Burton Suedel, Maik Flanagin, and Jeff Corbino

5e. TASK NUMBER

5f. WORK UNIT NUMBER

7. PERFORMING ORGANIZATION NAME(S) AND ADDRESS(ES)

8. PERFORMING ORGANIZATION REPORT NUMBER

U.S. Army Engineer Research and Development Center (ERDC)

Environmental Laboratory (EL)

ERDC TR-17-5

3909 Halls Ferry Road

Vicksburg, MS 39180-6199

9. SPONSORING I MONITORING AGENCY NAME(S) AND ADDRESS(ES)

Engineering With Nature

U.S. Army Engineer Research and Development Center (ERDC)

Environmental Laboratory (EL)

3909 Halls Ferry Road

Vicksburg, MS 39180-6199

12. DISTRIBUTION / AVAILABILITY STATEMENT

Approved for public release; distribution is unlimited.

\section{SUPPLEMENTARY NOTES}

\section{ABSTRACT}

A multifactor ecosystem assessment of dredged material supported wetlands was conducted within the Atchafalaya River, Louisiana. The assessment included evaluations of (1) geomorphic evolution, (2) ecosystem classification and distribution, (3) floral communities, (4) avian communities, (5) aquatic invertebrates, (6) soils and biogeochemical activity, and (7) hydrodynamic and sediment transport processes. Results indicate that the innovative use of dredged materials in a riverine environment supports wetland formation and expansion while providing habitat, hydrologic, and biogeochemical functions. The strategic placement of dredged materials in locations that mimic natural process promoted additional ecological benefits, especially regarding wading bird and infaunal habitat, thus adhering to Engineering With Nature (EWN) processes. The multifactor approach improved the wetland assessment, allowing for a comprehensive ecosystem-level analysis of a diverse array of ecosystem components and functions.

\section{SUBJECT TERMS}

Atchafalaya River (La.), DOER, Dredging spoil, Engineering With Nature, Environmental engineering, EWN, Geomorphology, Species diversity, Wetland ecology, Wetland restoration, Wetlands

\section{SECURITY CLASSIFICATION OF:}

\section{a. REPORT}

Unclassified

\section{b. ABSTRACT}

Unclassified c. THIS PAGE

Unclassified
17. LIMITATION OF ABSTRACT

SAR
18. NUMBER OF PAGES

108 19a. NAME OF RESPONSIBLE PERSON

19b. TELEPHONE NUMBER (include area code) 